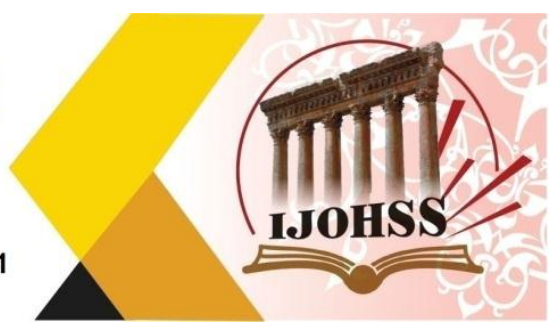

\title{
طبيعة سلوك سأم الإنتظار لاى طلبة الجامعة
}

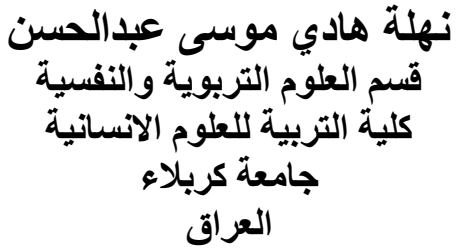

البريد الاكتروني: najafnahla@gmail.com n n

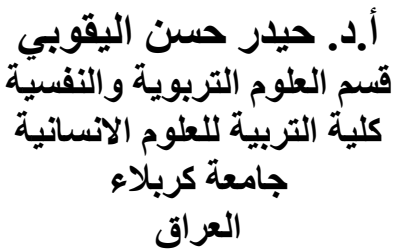

العراق

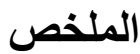

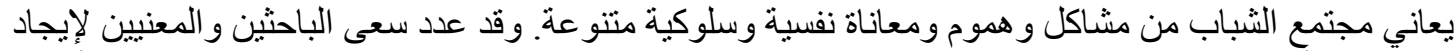

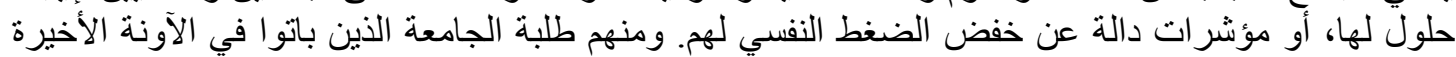

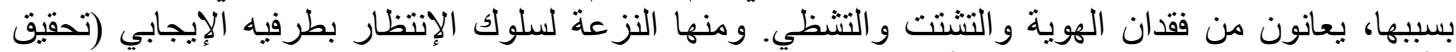

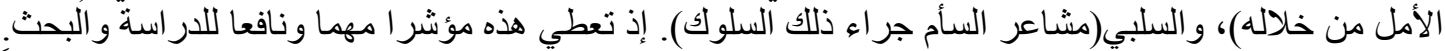

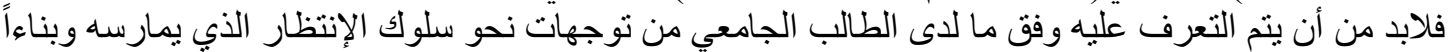

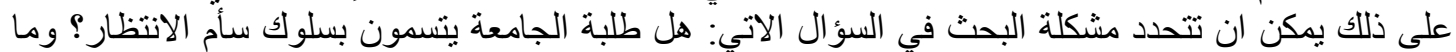

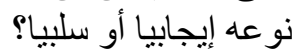

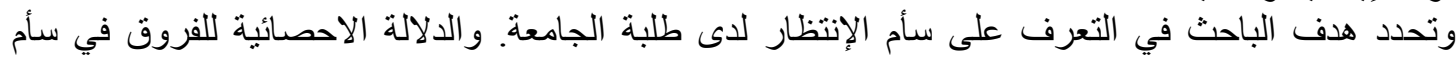

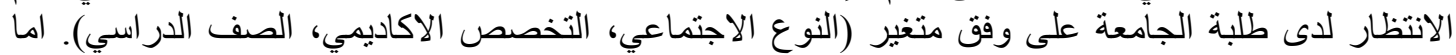

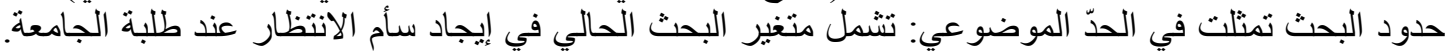

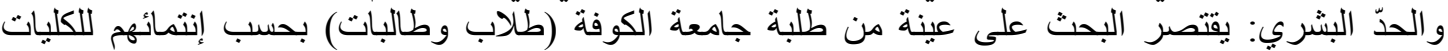
العلمية والإنسانية. و الحدّ المكاني: إقتصر البحث على البى الطلبة في مبنى جامعة الكوفة. والحدّ الزماني: للعام الدر اسي (2020-2021م) (1441-1442ه). تبنى الباحثان تعريف تمار ناجي 2014. أما التعريف الإجرائي سيكون: الدرجة الكلية التي يحصل عليها

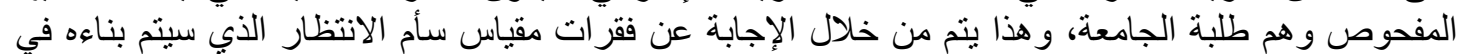

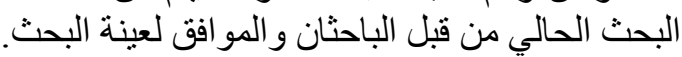
تناول في الإطار النظري كل من البالن الابعاد النظرية لمفهوم السأم، ومفهوم السأم في الأدبيات العلمية، ونظرية

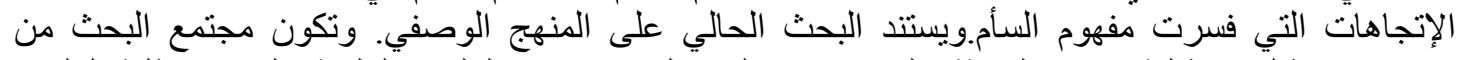

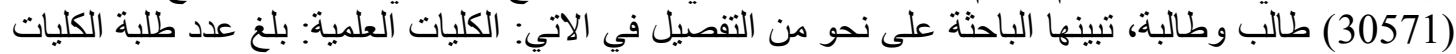

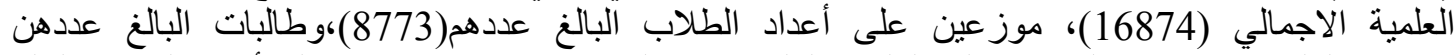

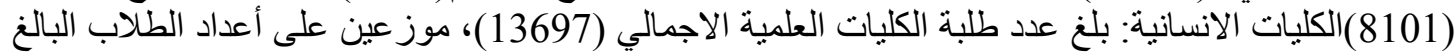

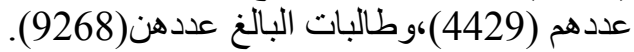
ولغرض تحقيق هدفا البحث الحالي قام الباحثان بيناء مقياس البحث (سأم الانتظار) و التحقق من الخصائص السيكو منرية للفقر ات و المقياس ككل. 


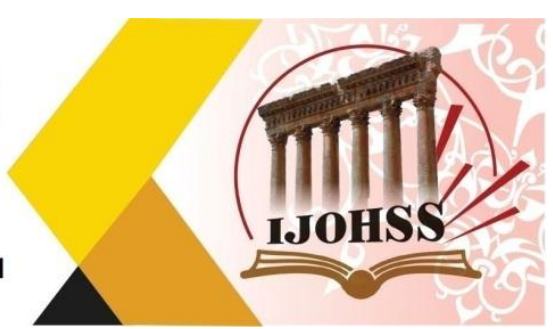

\title{
The Nature of The Boredom of Waiting Behavior among University Students
}

\author{
Prof. Dr. Haider Hassan Al-Yaqoubi \\ Department of Educational and \\ Psychological Sciences \\ College of Education for Human \\ Sciences \\ Karbala University \\ Iraq
}

\author{
Nahla Hadi Musa Abdulhassan \\ Department of Educational and \\ Psychological Sciences \\ College of Education for Human \\ Sciences \\ Karbala University \\ Iraq \\ Email: najafnahla@gmail.com
}

\begin{abstract}
Today, the humanitarian community is generally suffering from multiple psychological problems, because of a number of personal and social compressive situations, as well as political motives or moral education. The youth community (especially) are suffering from problems, concerns and suffering from a variety of psychological and behavioral problems. The researchers and those involved are trying to find solutions or indicators to reduce psychological pressure. Of whom are university students who have recently due to these problems, lost their identity, dispersed and fragmented, and pushed them to look for an outlet they are waiting for their personal, social and future needs in general.

The tendency to behavior is a positive craft (achievement of hope), and the teacher (Senus Bored). Give an important indicator of study and research. It must be recognized in accordance with the university student Maldi, for notes of cases of laziness, despair, communication and depression. Many people, including university students are eager to a position that changes their cases in case of time. Perhaps they differ with some of them in terms of different characters and forms. So personal features may be a scientific intervention in the adoption of these students to behavior, or poison. This diversity in those features will give a clear scientific indicator, and therefore can be predicted and then provide solutions. As a result, the search problem in question can be determined: are university students characterized by bored waiting? What is it relationship with their personal features?!.
\end{abstract}

Keywords: Boredom of Waiting, University Students. 
website:www.ijohss.com

Email:editor@ijohss.com

ISSN: $2415-4822$
العدد (28) ديسمبر 2021

Volume (28) December 2021

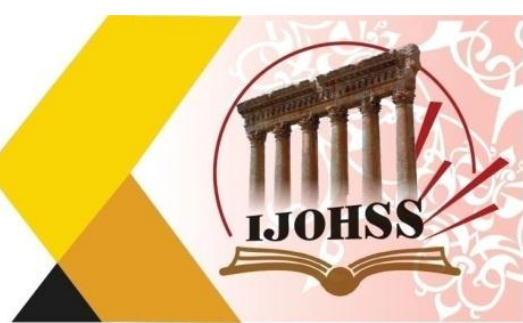

الفصل الاول: التعريف بالبحث Definition of the Search

The Research Problem : اولا: مشكلة البحن

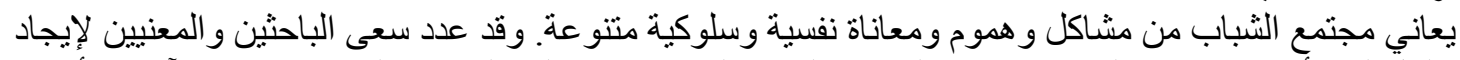

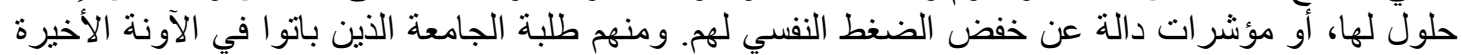

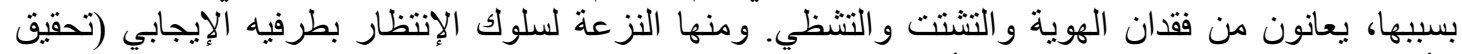

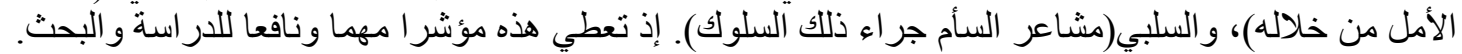

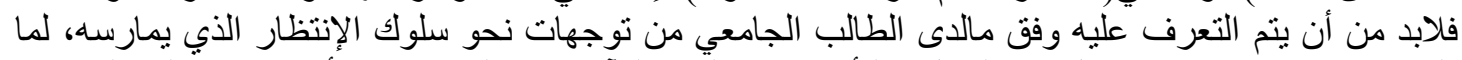

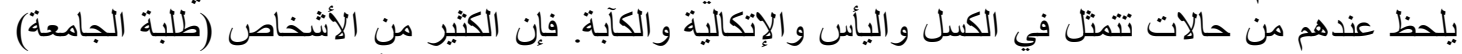

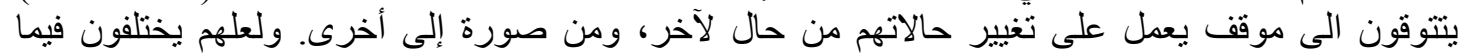

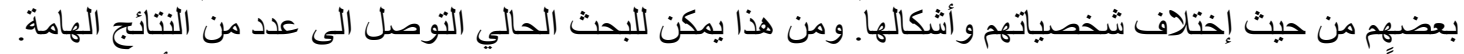

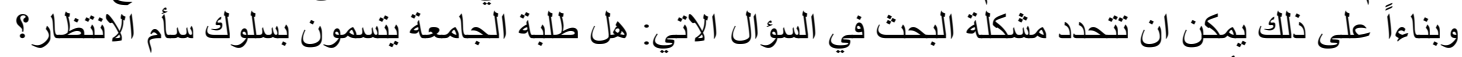

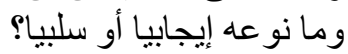

ثانيا: أهمية البحث: The Importance of the Research

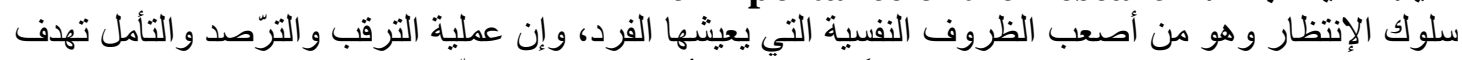

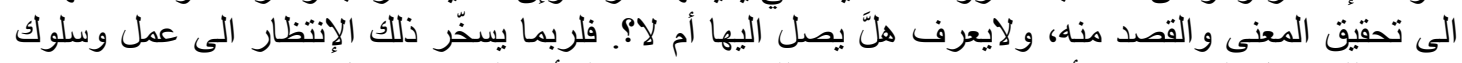

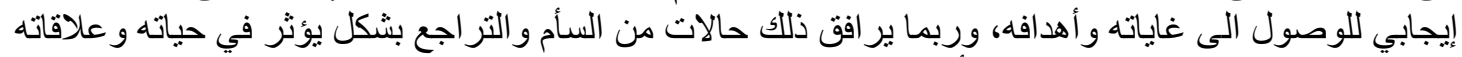

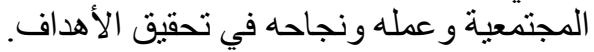

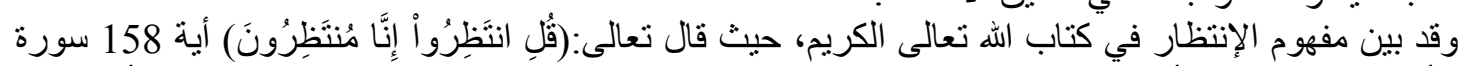

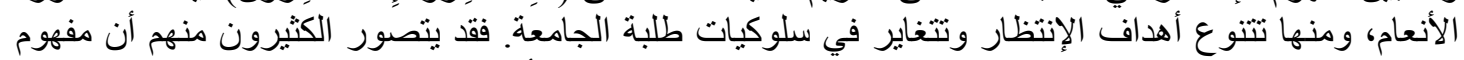

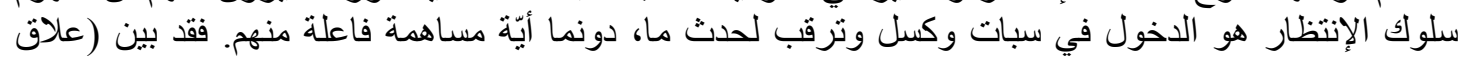

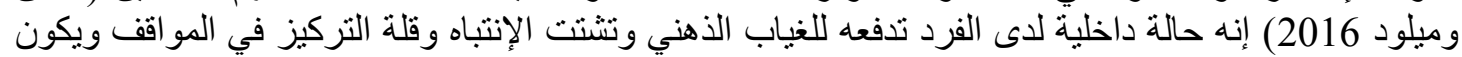

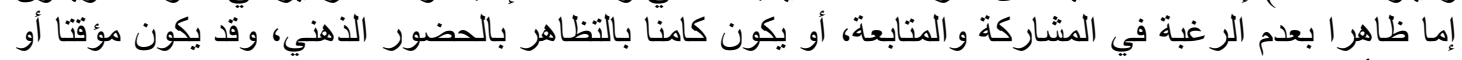

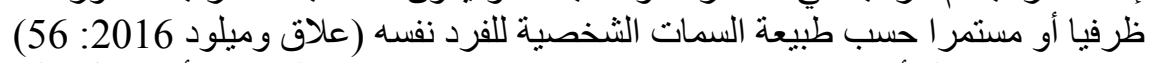

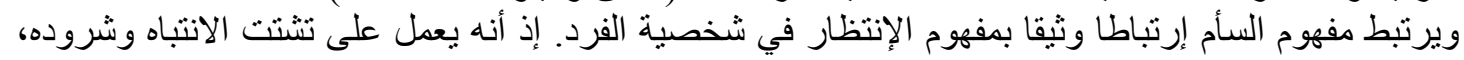

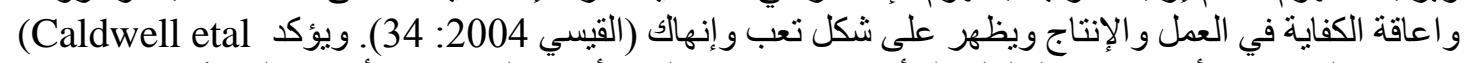

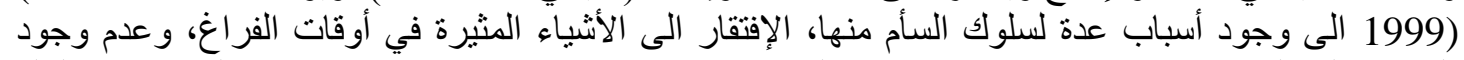

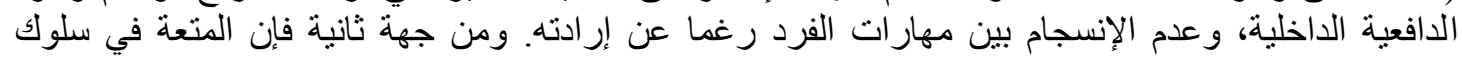

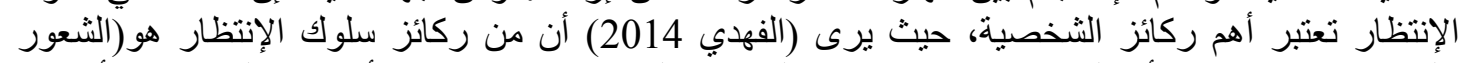

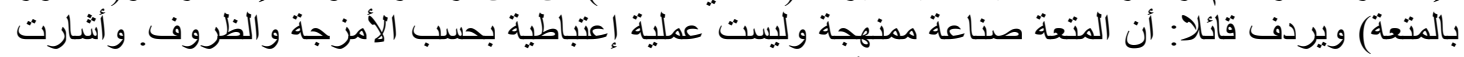

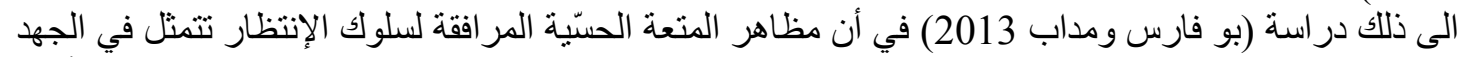

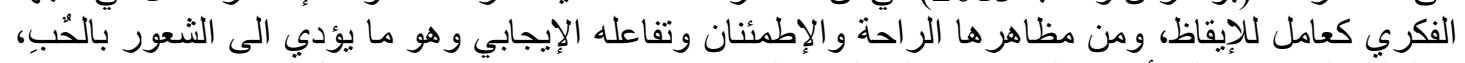

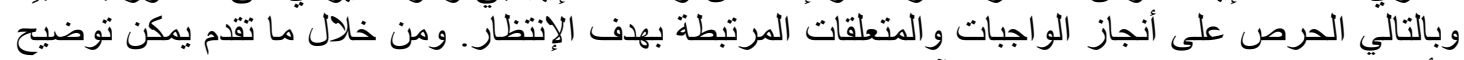

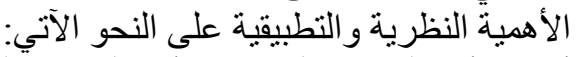

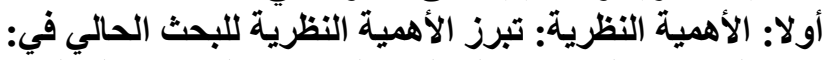

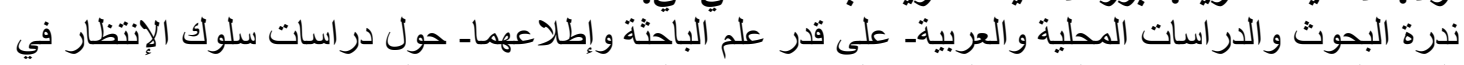

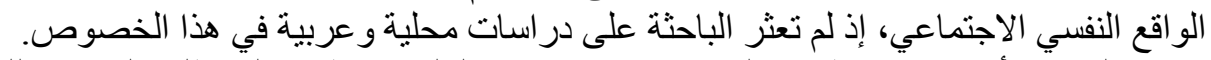

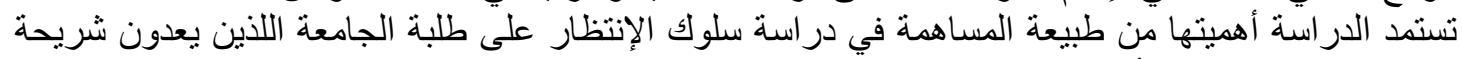

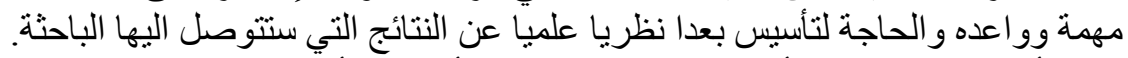

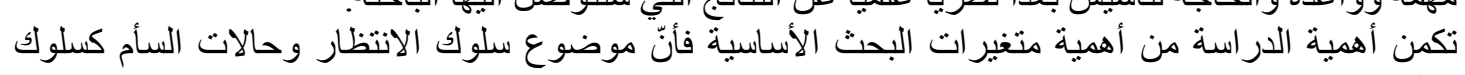

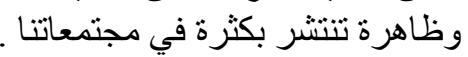




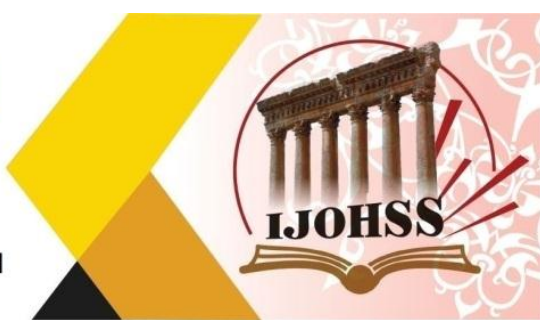

ثانياً: الأهمية التطبيقية: تسهم الاراسة الحالية من الناحية التطبيقية في الآتي:

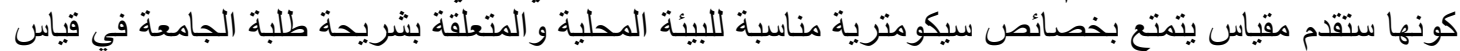

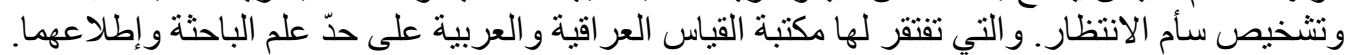

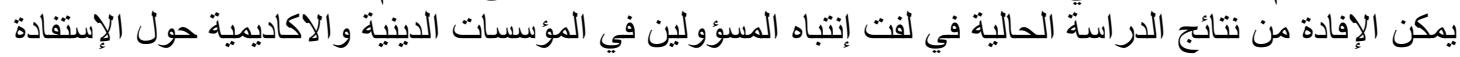

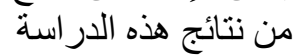
يمكن أن تساهم نتائج الدراسة الحالية في التوصل الى حقائق تتعلق بشخصية الطالب الجامعي ورؤيته المستقلية العقائدية و الإجتماعية و غيران النير ها.

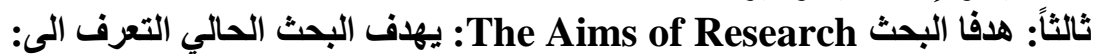
التعرف على سأم الإنتظار لأى طلبة الجامعة. الدلالة الاحصائية للفروق في سأم الانتظار لإى طلبة الجية الجامعة على وفق متغير (النوع الاجتماعي، التخصص

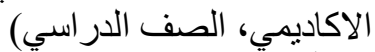

رابعاً: حدود البحـثـ: Limitations of the Research يتحدد البحث الحالي بالحدود الآتية:

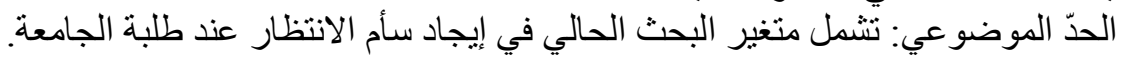

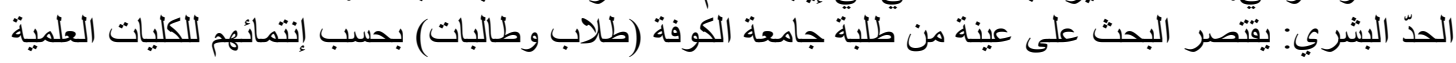
و الإنسانية. الحدّ المكاني: إقتصر البحث على الطلبة في مبنى جامعة الكوفة

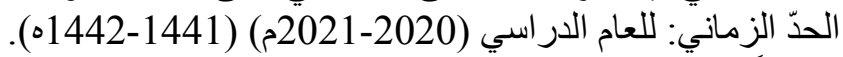

خامساً: تحديد المصطلحات: Definition of The Terms

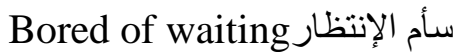
عرفه (الغزوي واخرون 2000) بأنه سلوك إجتماعي تكيّفي يسعى فيه الافراد اللى الترقب لتحقيق الحاجات

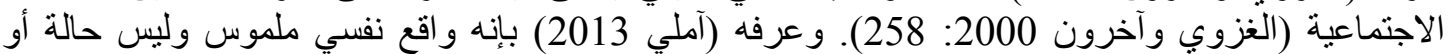

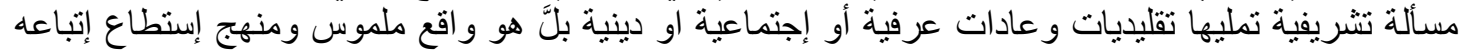

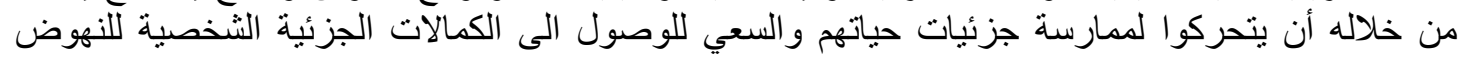

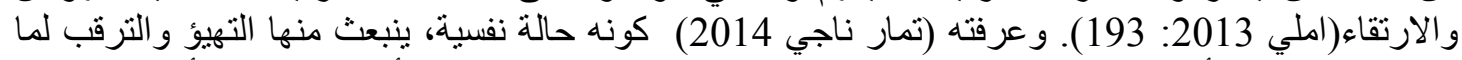

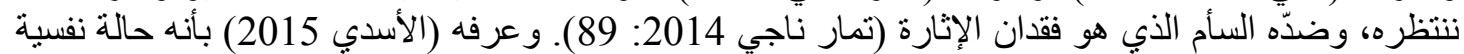

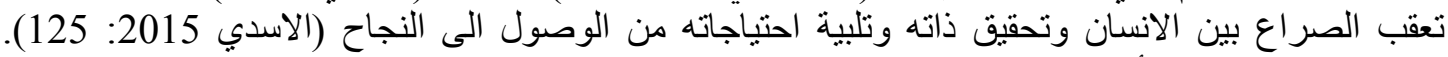

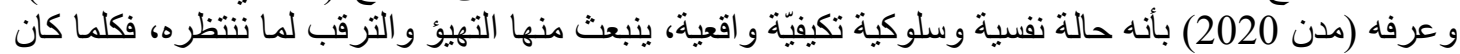

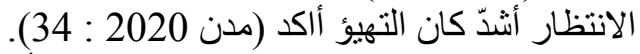

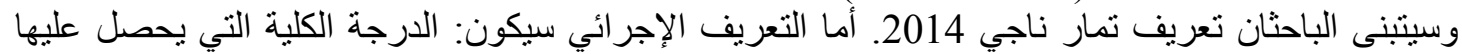

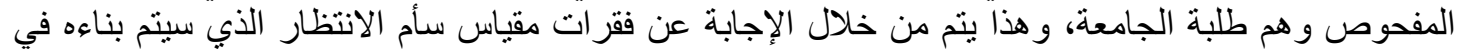
البحث الحالي من قبل الباحثان و المو افق لعينة البحث.

\section{الفصل الثاني :إطار النظري، نظريات مفسرة، دراسات سابقة:

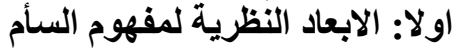

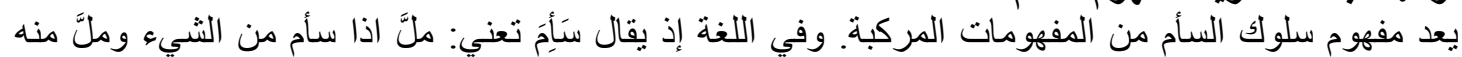

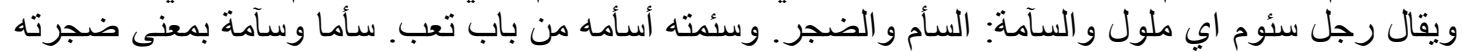

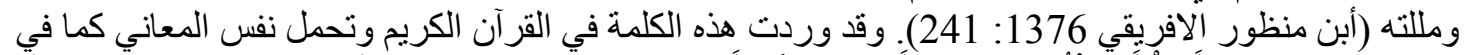

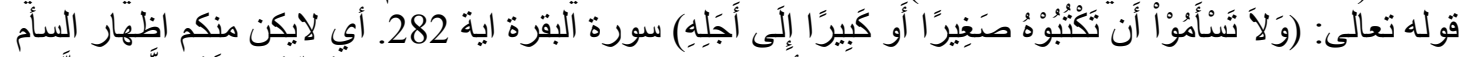

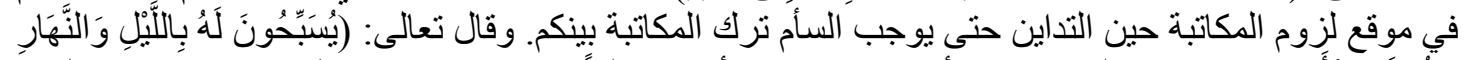

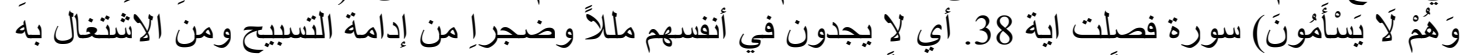

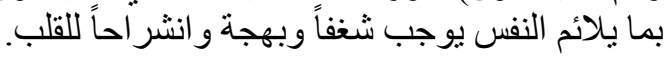




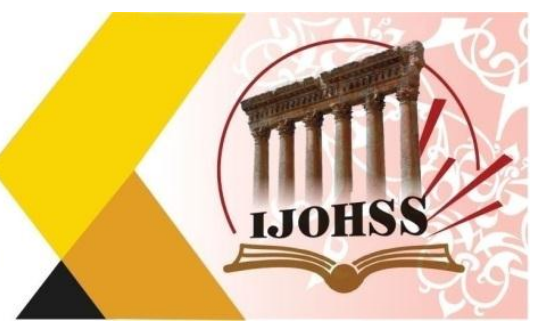

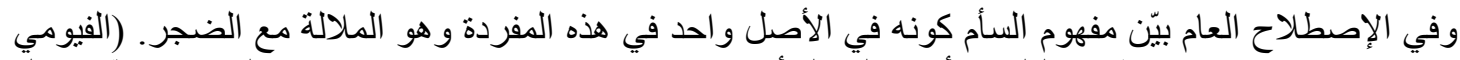

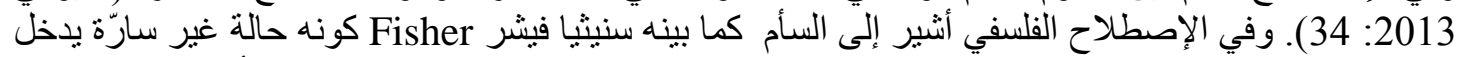

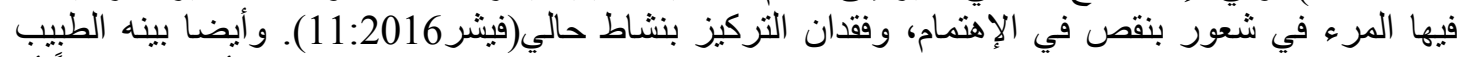

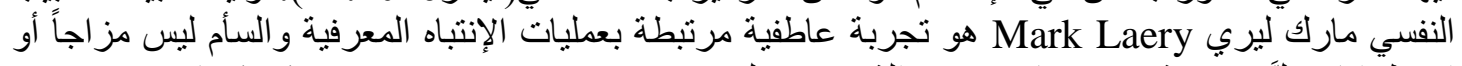

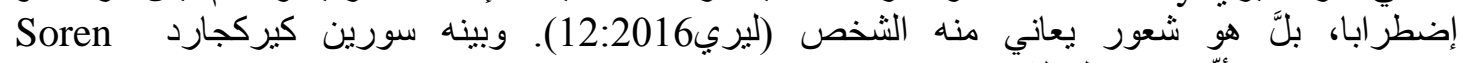
Kierkegaard وفي الإصطلاح النفسي بينه سيب (Seib 1998) هو النقص فئس في التحفيز الخارجي ونقص في قدرة الفرد

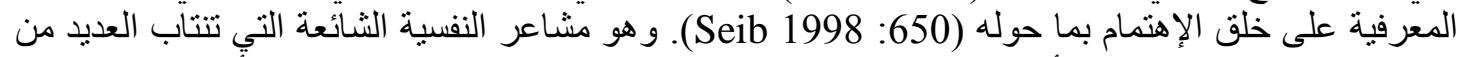

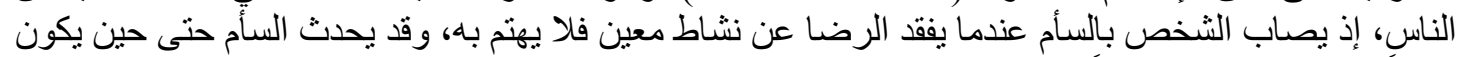

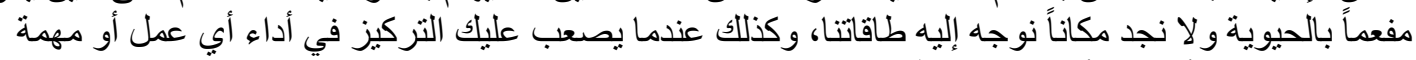
ثانيا: مفهوم السأم في الأدبيات العلمية الكية

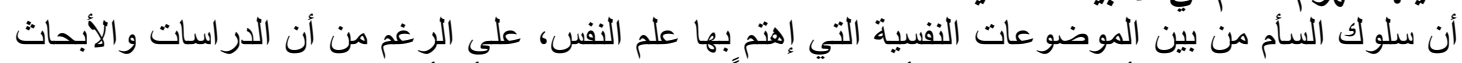

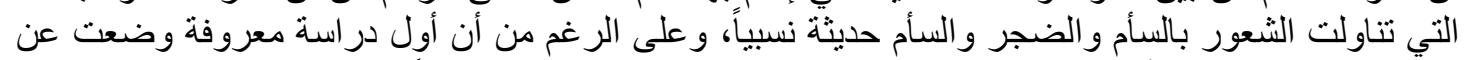

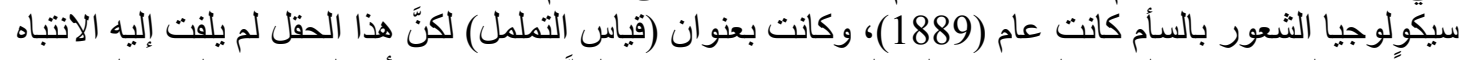

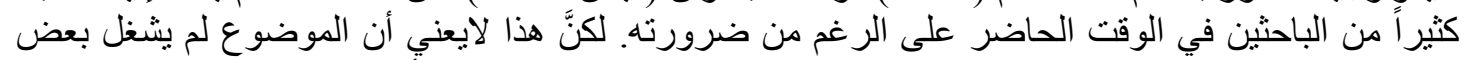

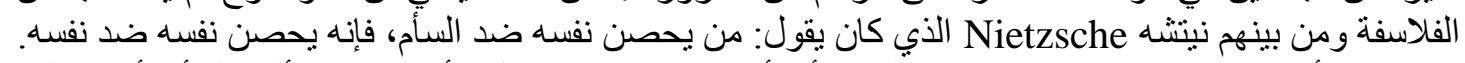

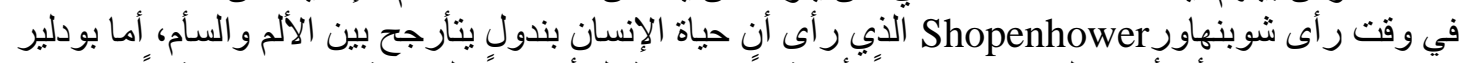

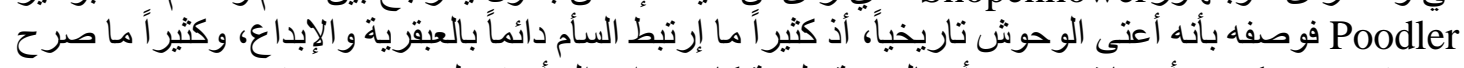

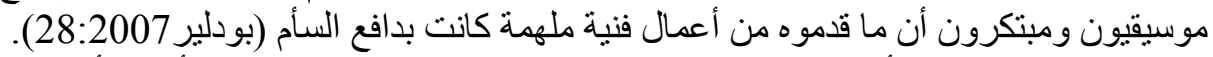

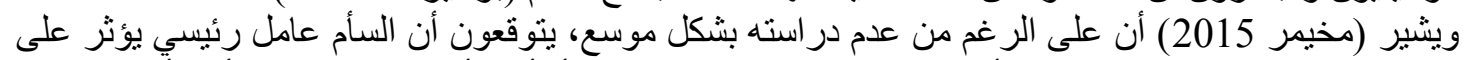

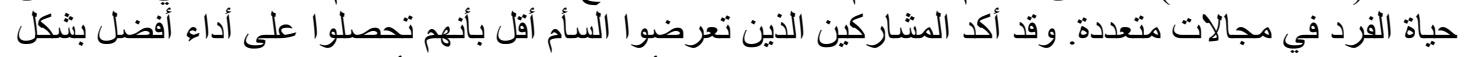

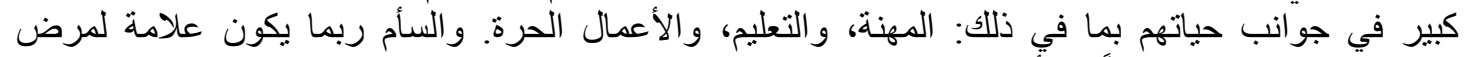

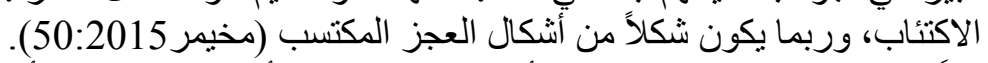

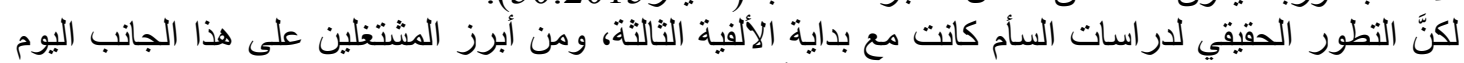

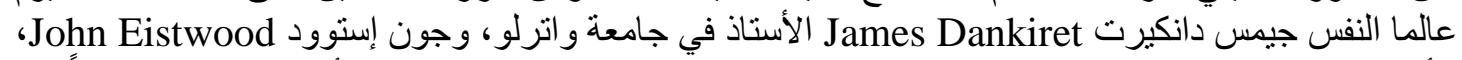

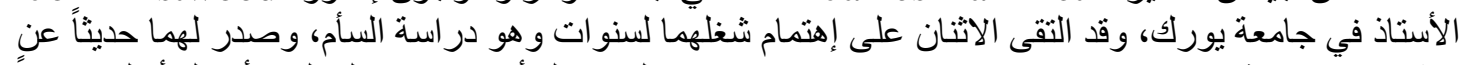

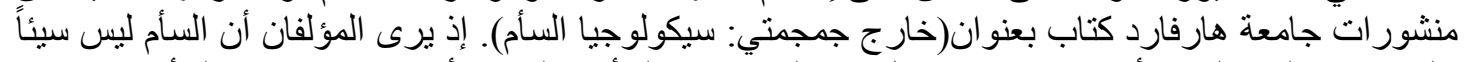

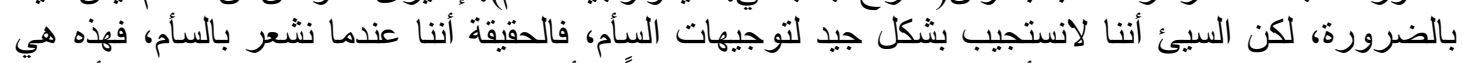

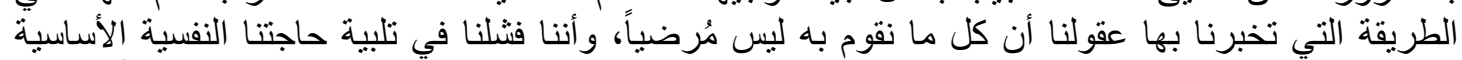

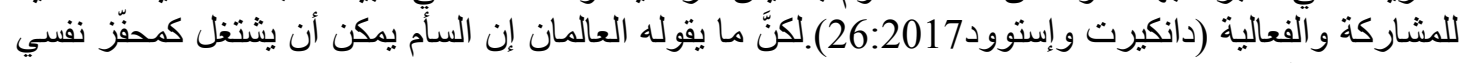
نحن بحاجة إليه (دانكيرت و إستوود (27:2017).

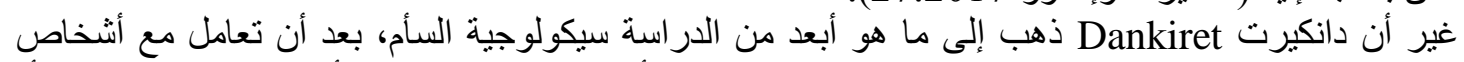

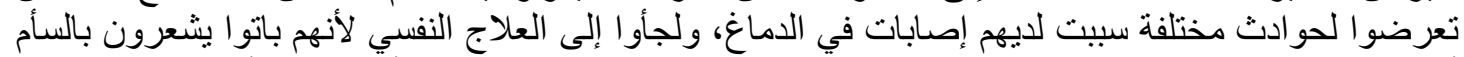

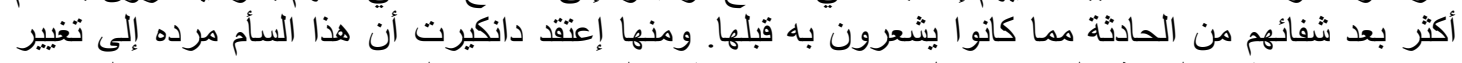

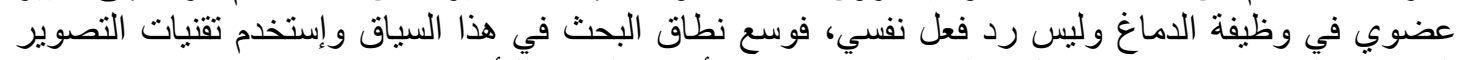

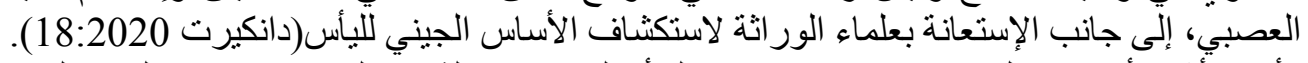

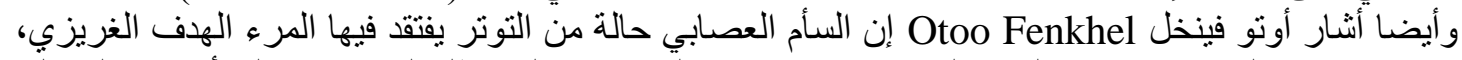

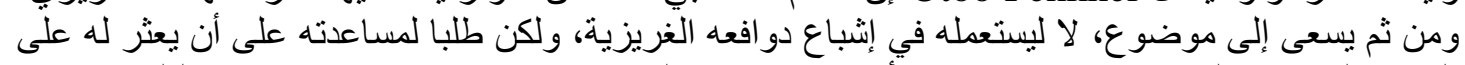

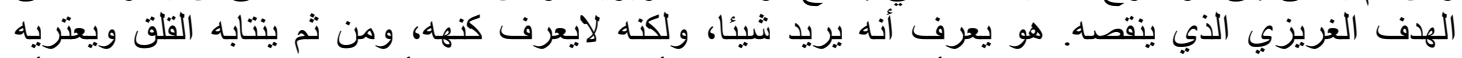

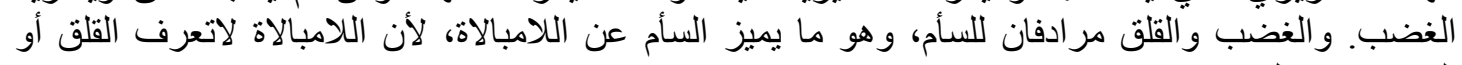
الغضب (فينخل 24:2006)

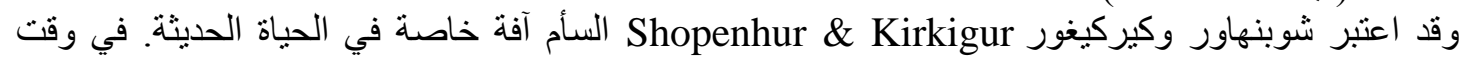

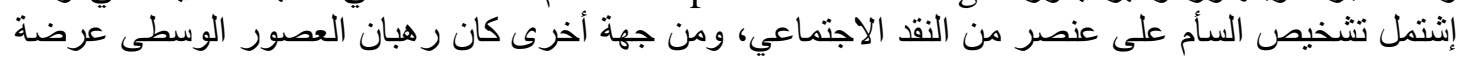




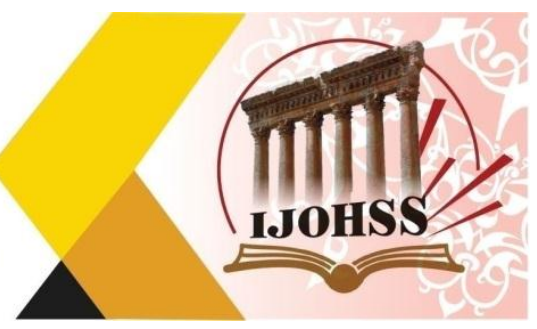

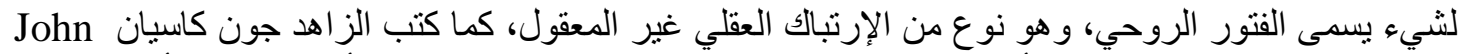

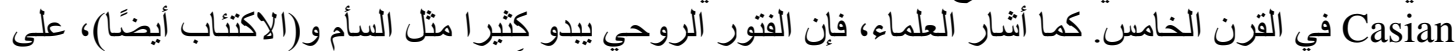

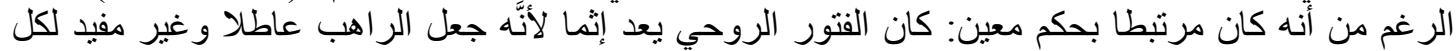

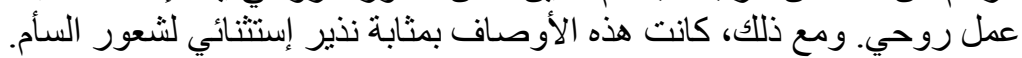

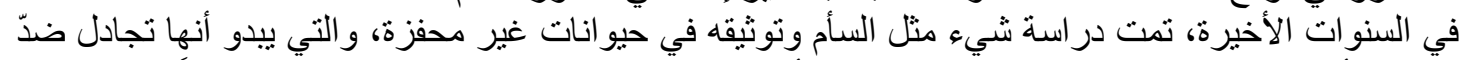

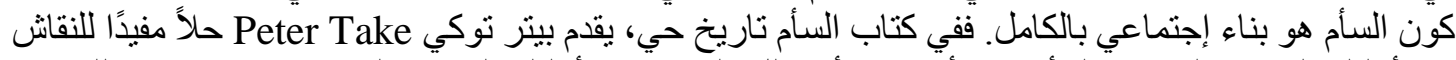

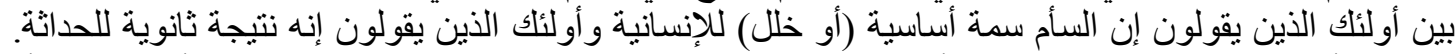

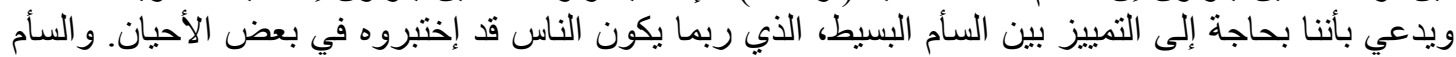

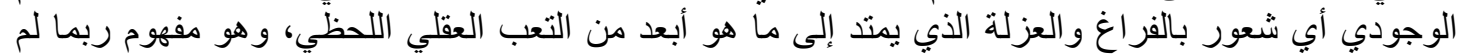

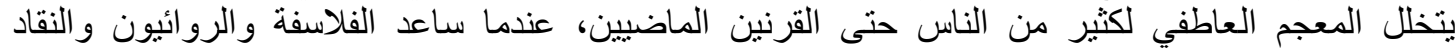

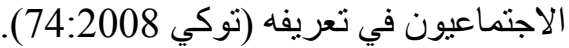

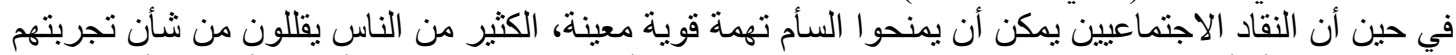

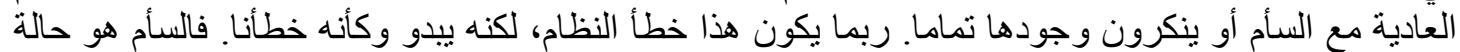

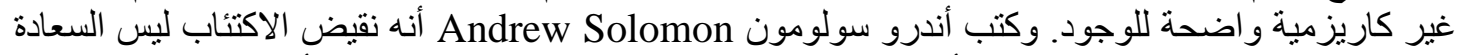

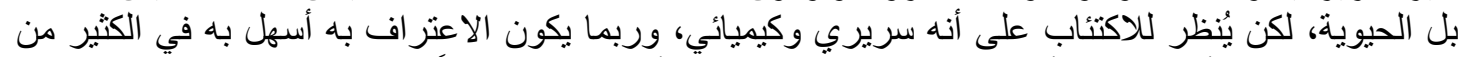

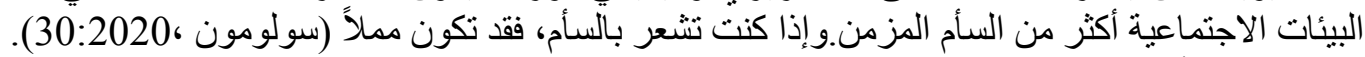

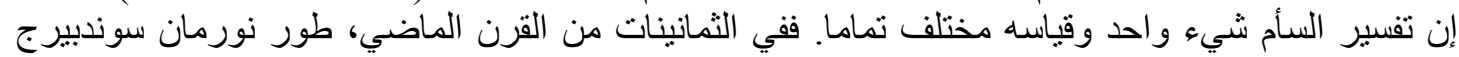

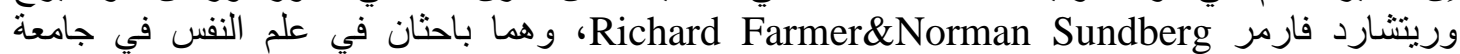

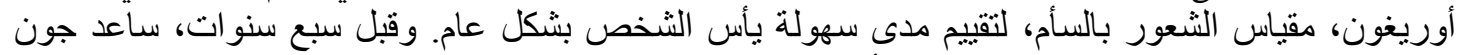

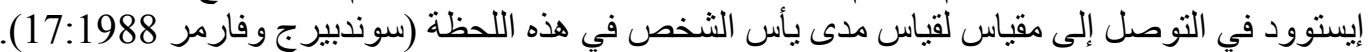

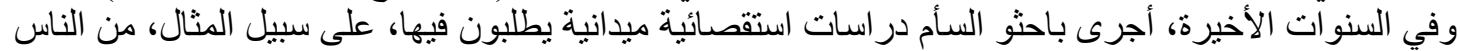

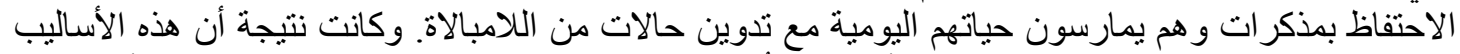

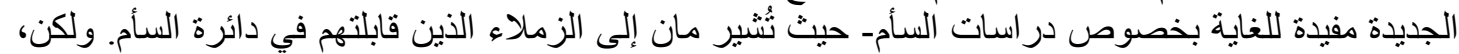

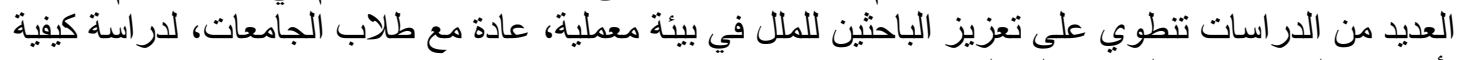

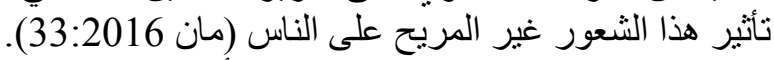

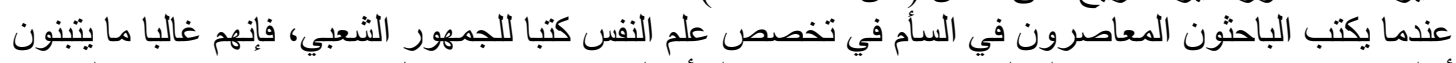

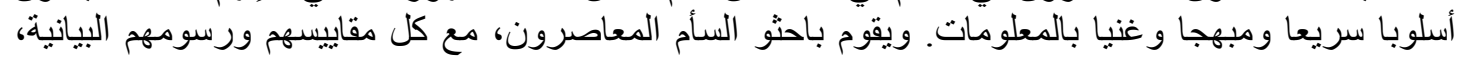

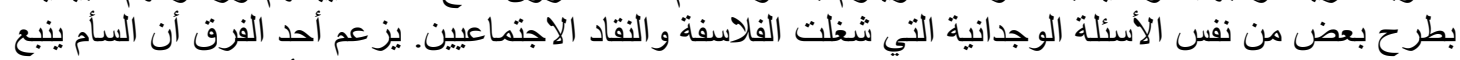

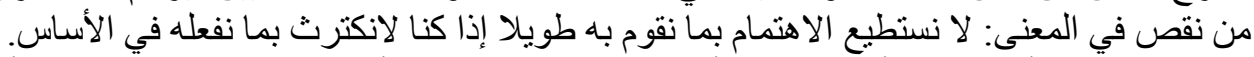

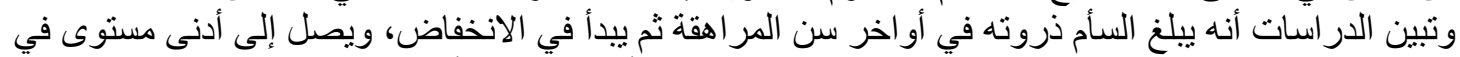

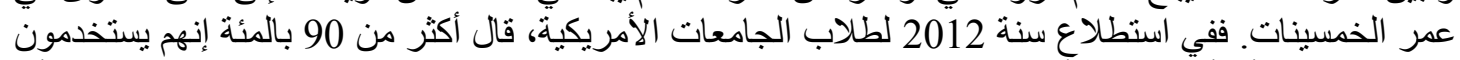

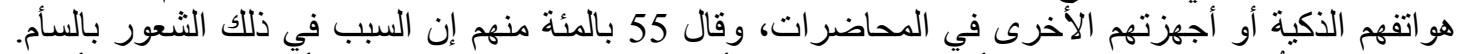

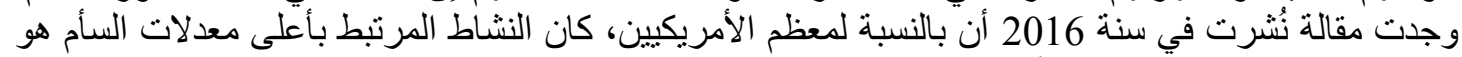

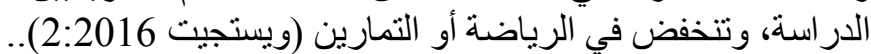

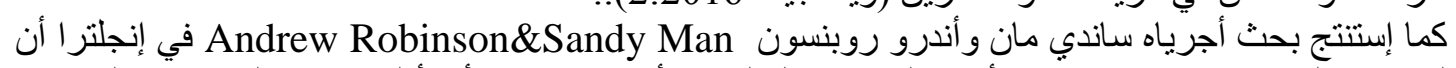

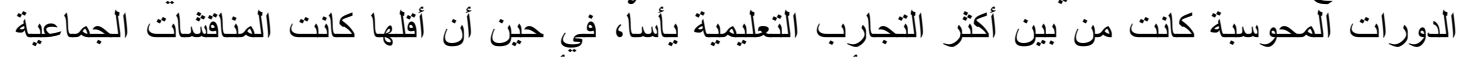

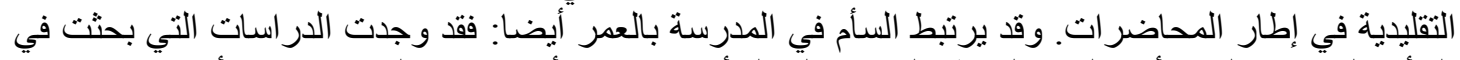

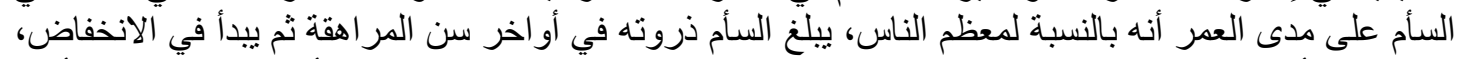

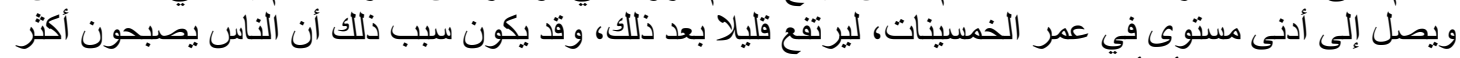

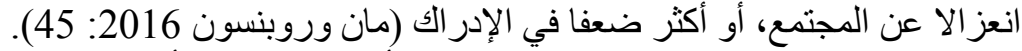

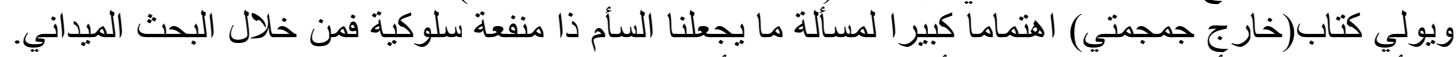

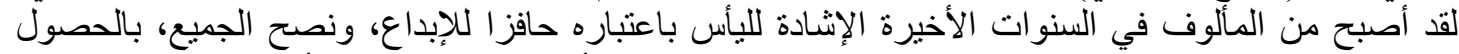

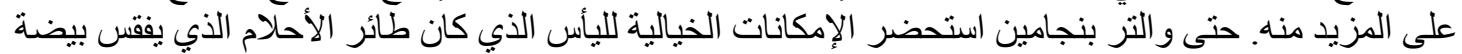




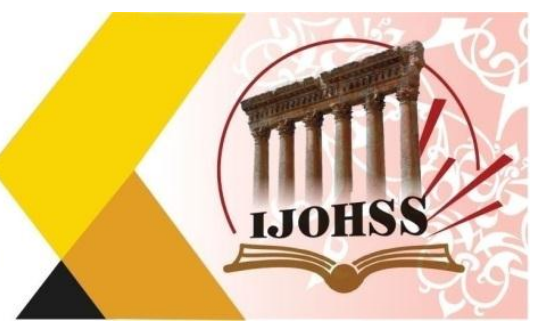

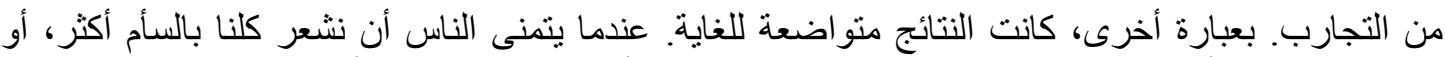

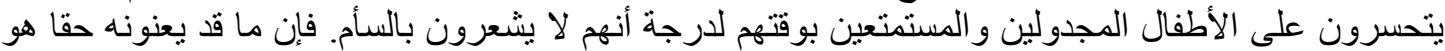

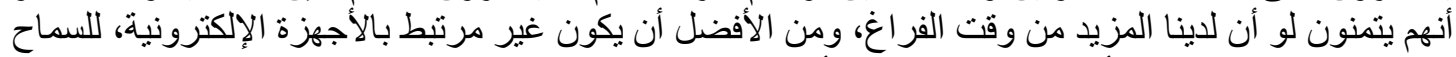

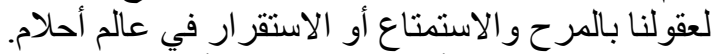

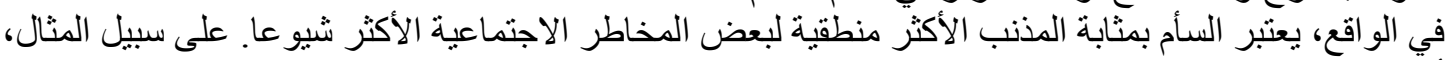

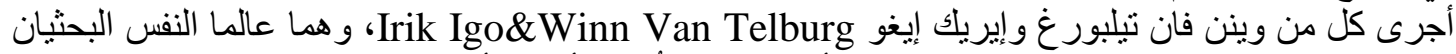

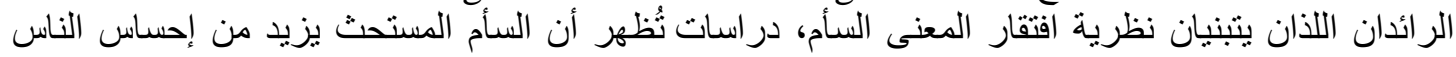

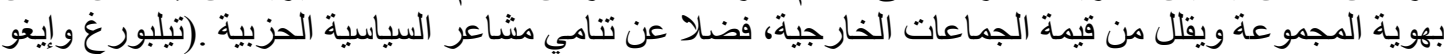
. (2017

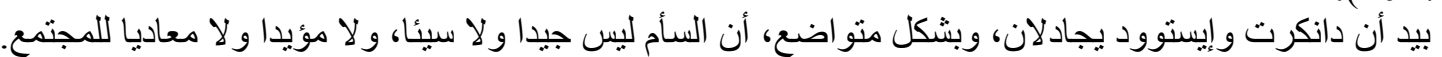

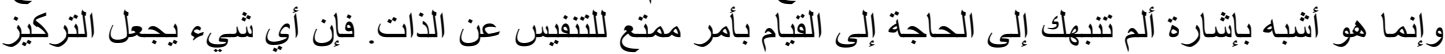

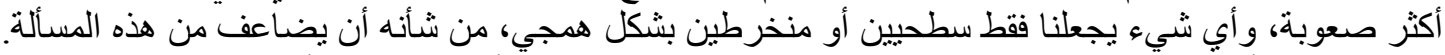

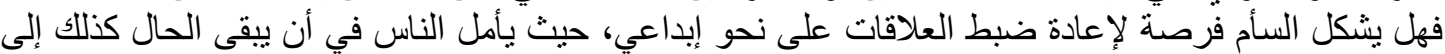

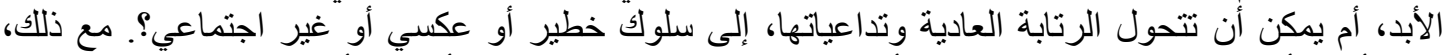

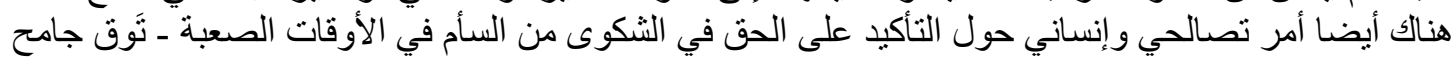
إلى الحياة العادية وتتوع الحياة.

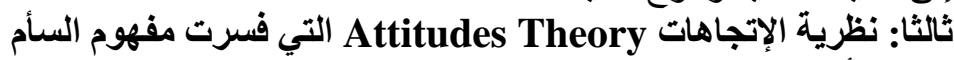

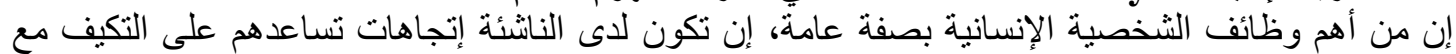

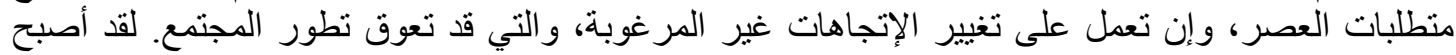

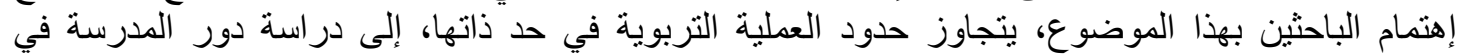

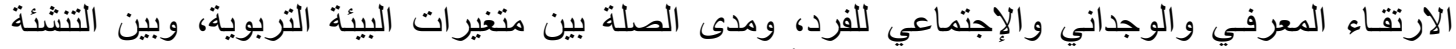

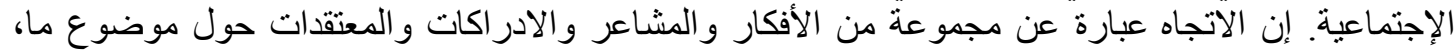

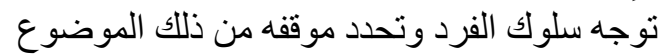

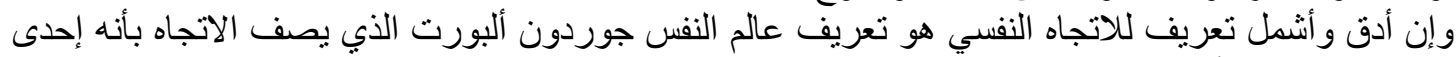

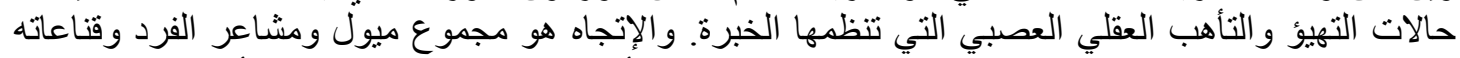

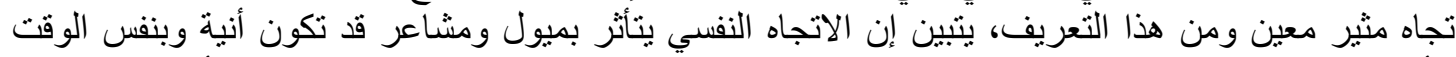

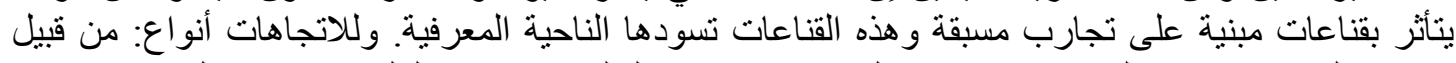

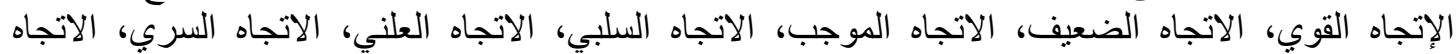

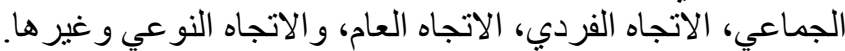

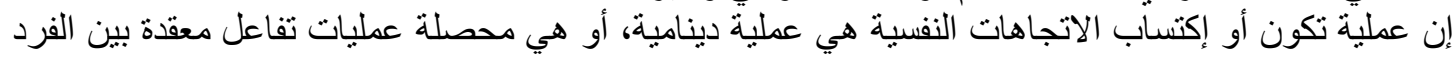

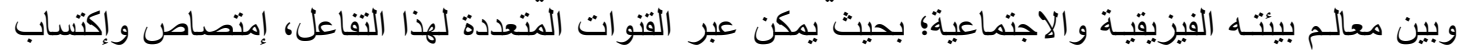

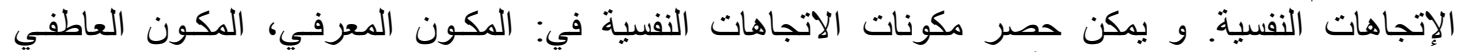

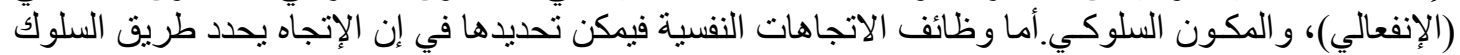

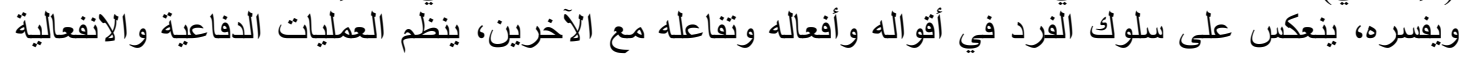

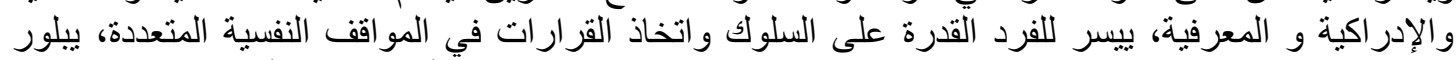

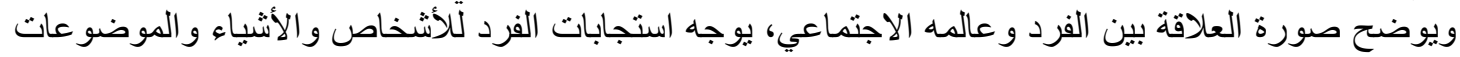

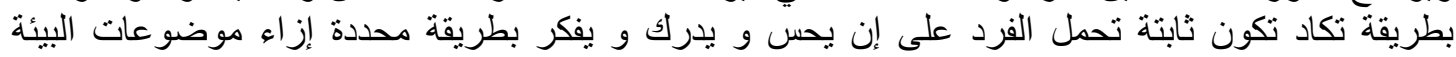

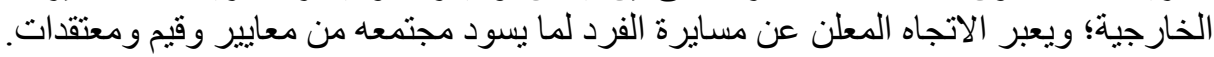

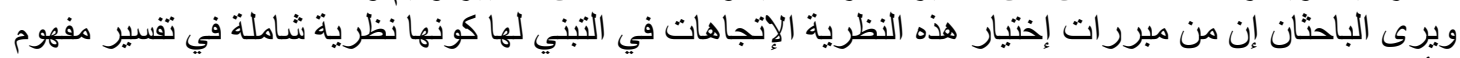

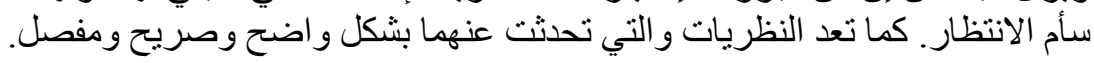




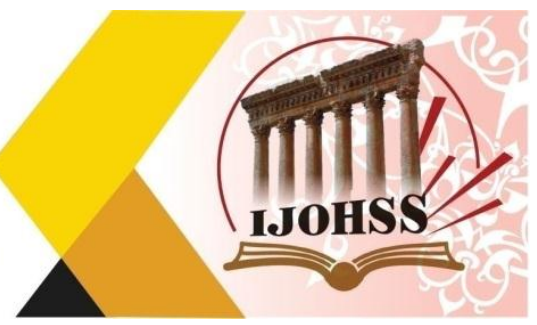

رابعا: دراسات سابقة: من الاراسات التي تناولت سأم الانتظار هي :

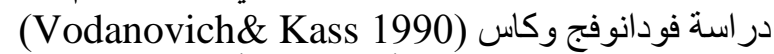

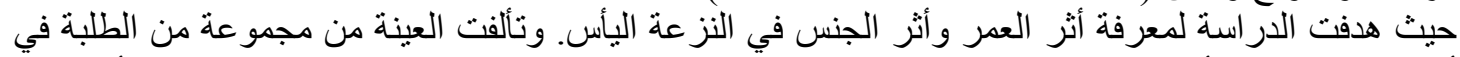

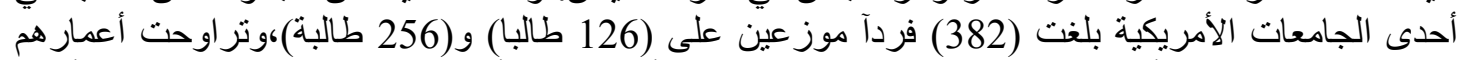

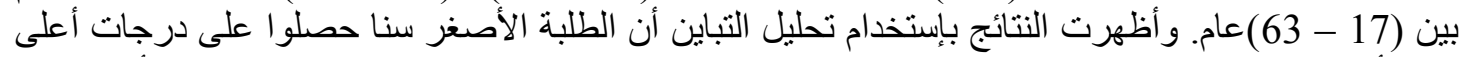

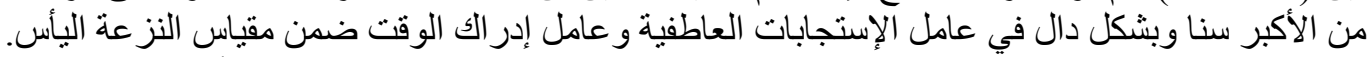

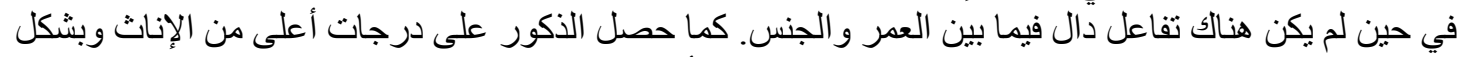

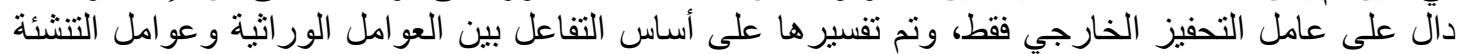

الإجتماعية (Vodanovich\& Kass 1990: 297).

در اسة داهلن وأخرين (Dahlin etal 2005)

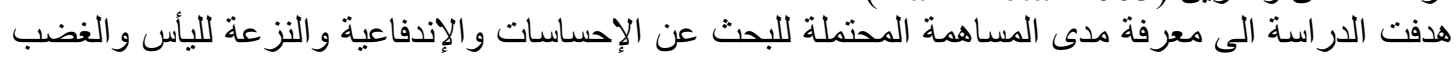

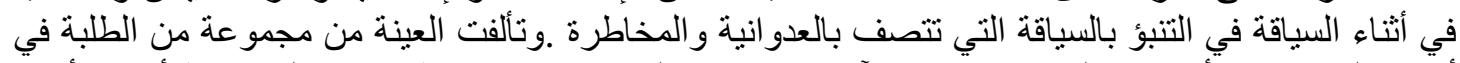

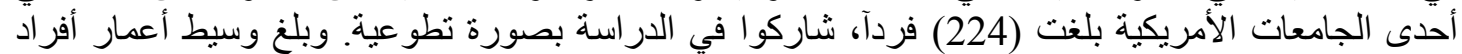

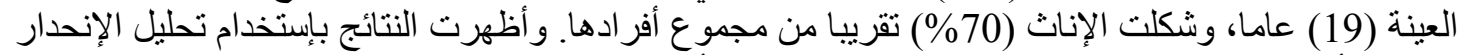

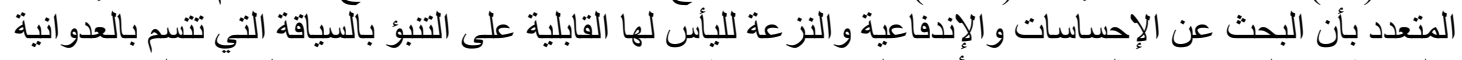

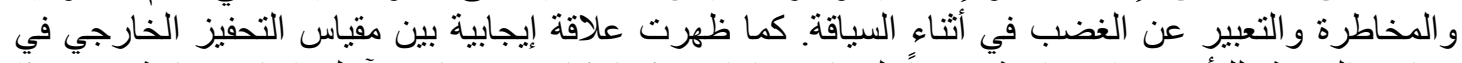

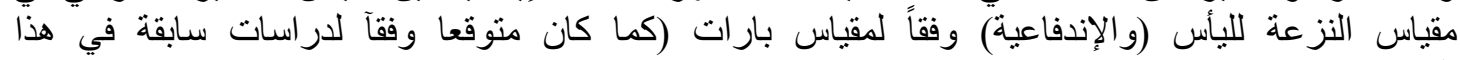
الجانب(Dahlin etal 2005: 341)

\section{الفصل الثالث : إجراءات البحث}

أولا: منهجية البحث: Method of the Research يستند البحث منهية الحالي على المنهج الوصفي، إذ يتم جمع المعلومات والبيانات من ثم تبويبها وتحليلها وقياسها

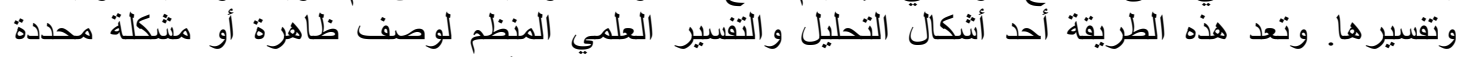

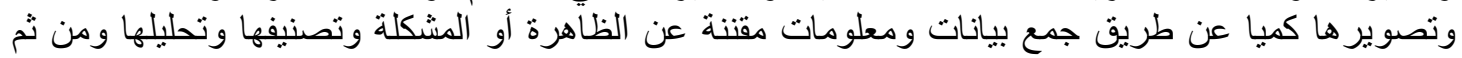

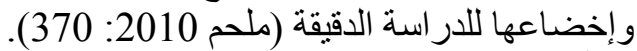

ثانياً: مجتمع البحث

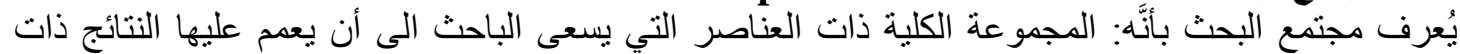

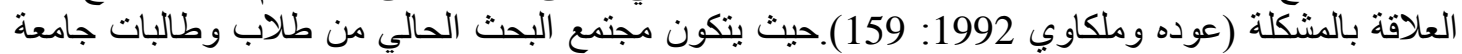

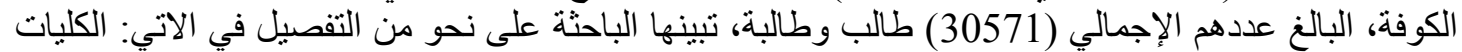

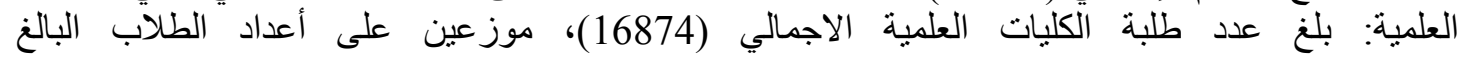

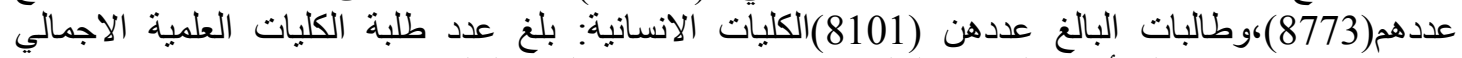

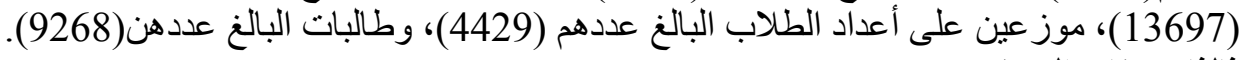

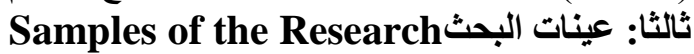
أو لا: العينة الاستطلاعية الاولية (عينة وضوح الفقرات و التعليمات) ونم إختيار العينة الاسنطلاعية بطريقة

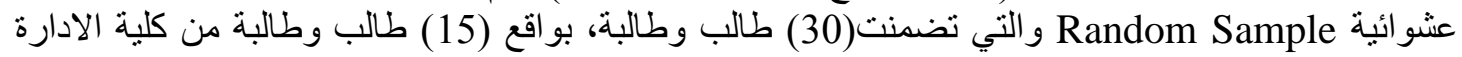

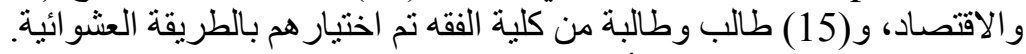

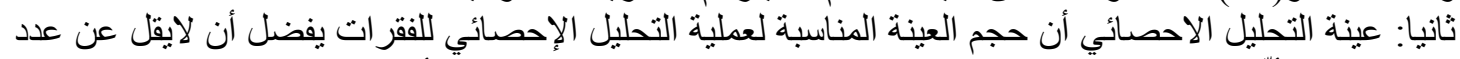

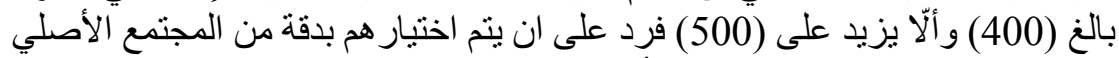

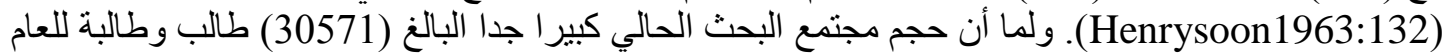

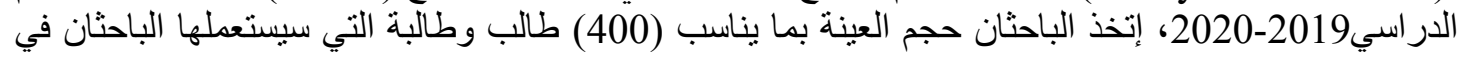
استخر اج القوة التمبيزية للفقرات، باستخدامها لاستخر اج الفروقات بين المجمو عتين الطرفيتين. 


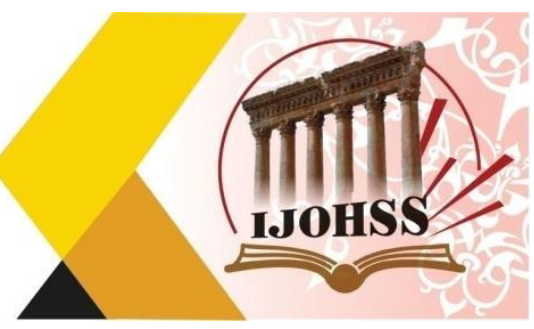

ثنالثا: عينة البحث الاساسية (عينة التطبيق)

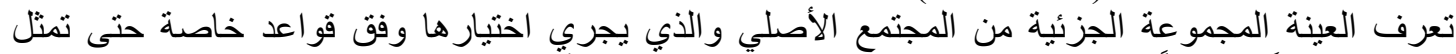

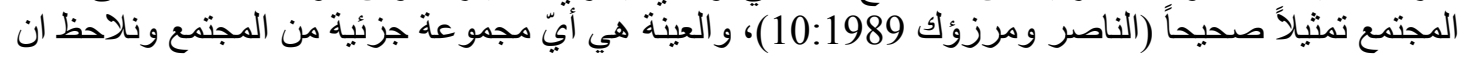

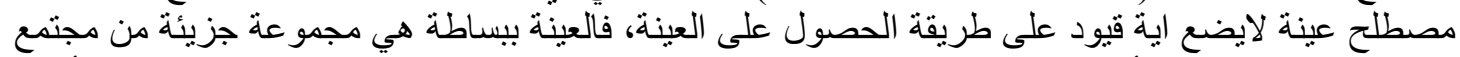

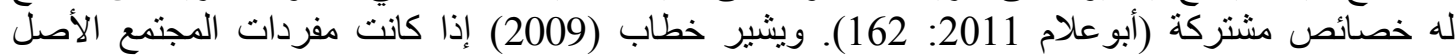

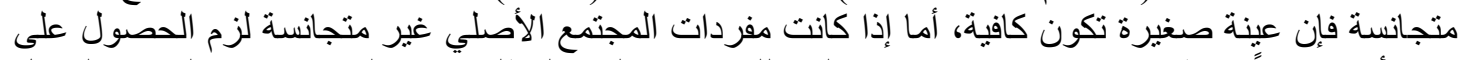

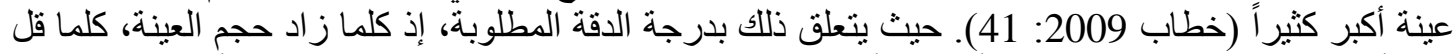

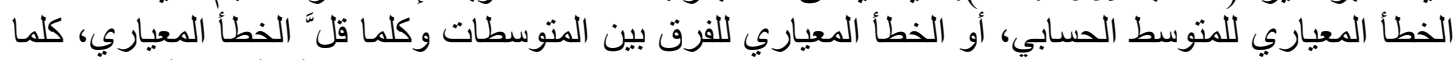

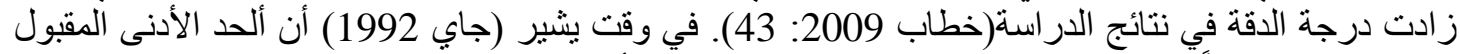

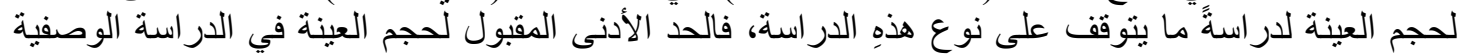

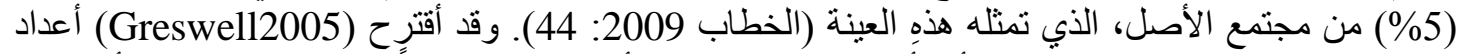

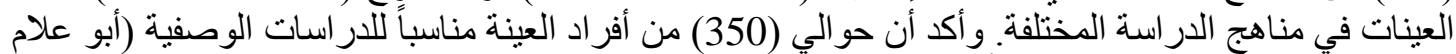

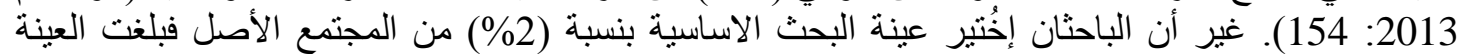

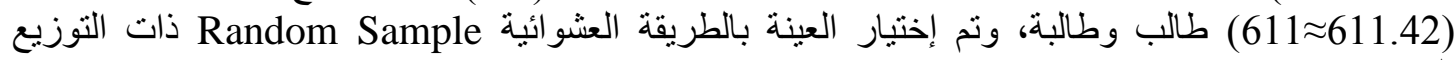

رابعاً :أداة البحث

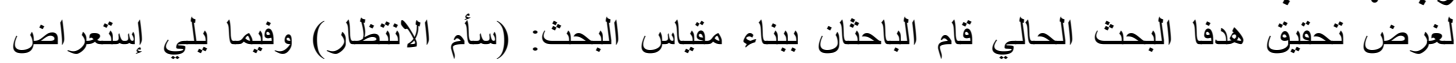

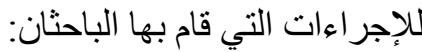

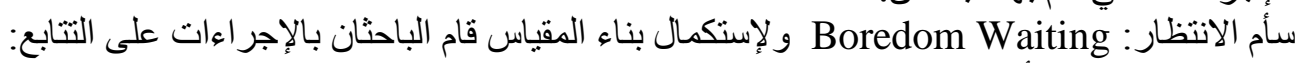

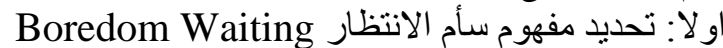

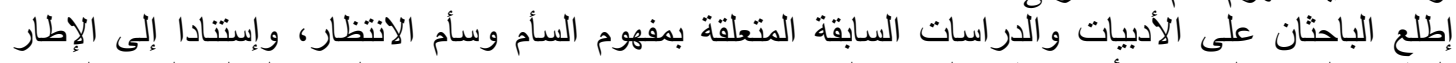

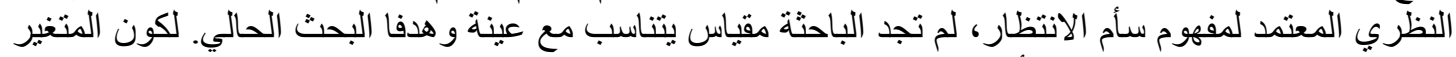

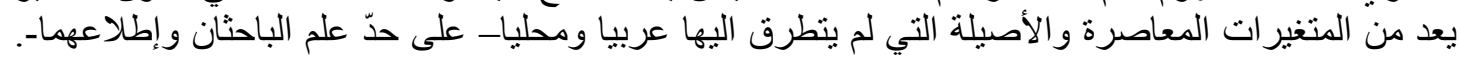

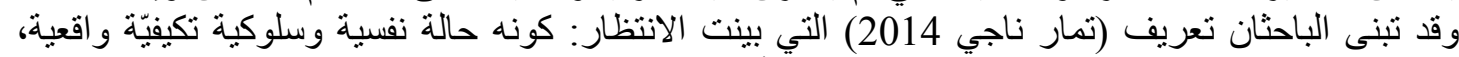

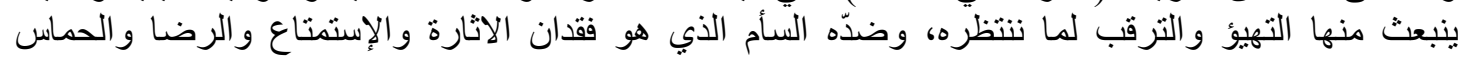

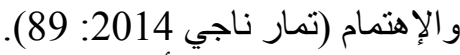

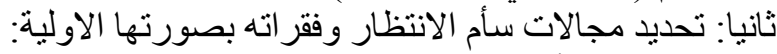

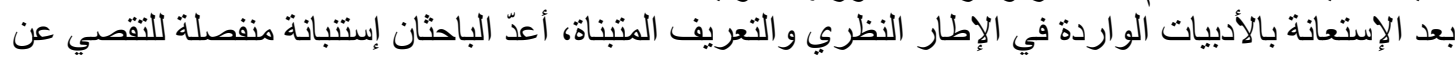
أيّ من تلاك المجالات أكثر تمثيلا للعينة الحالية (طلبة جامعة الكوفة) لقياس مفهوم سأم الانتظار للايهم، والتي التي التئي

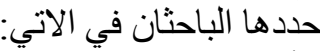

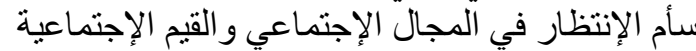

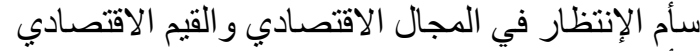

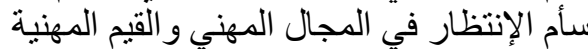

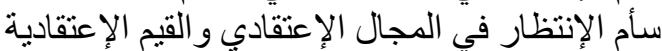

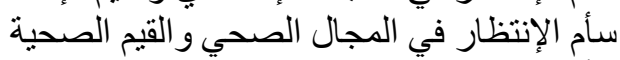

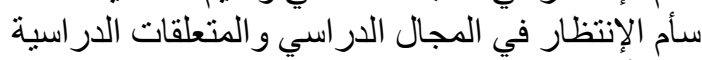

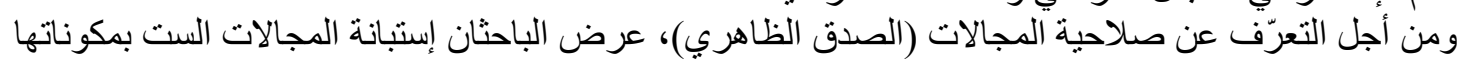

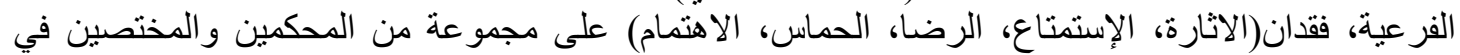

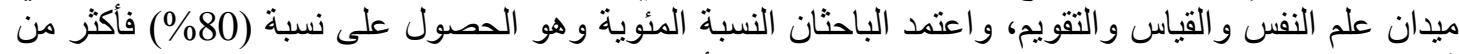

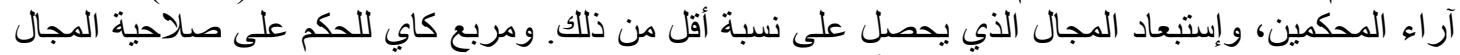

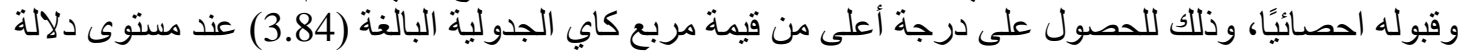

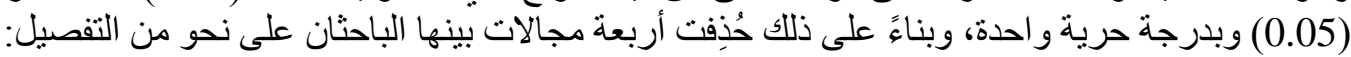




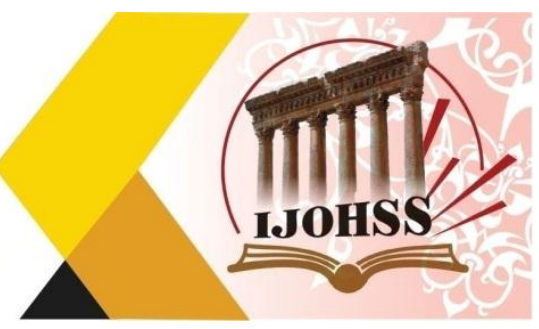

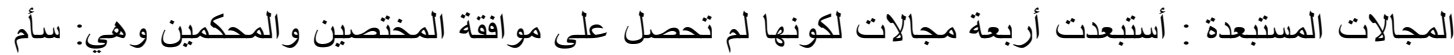

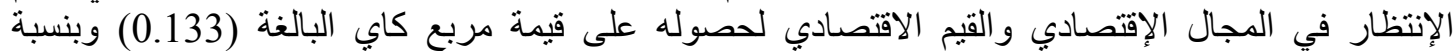

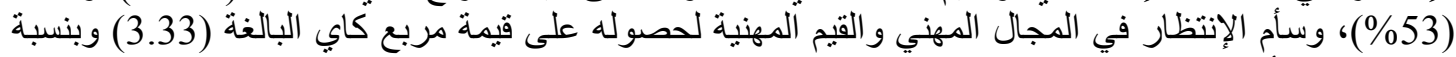

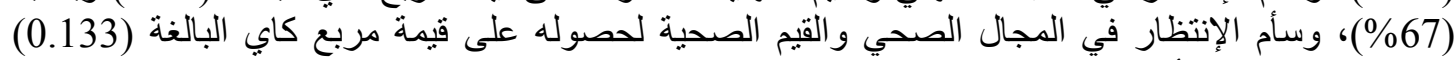

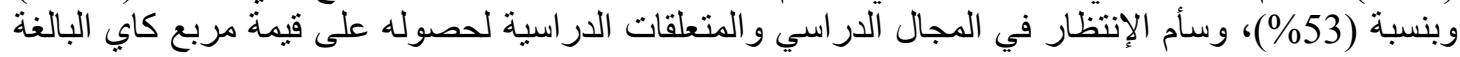

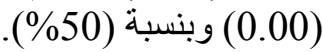

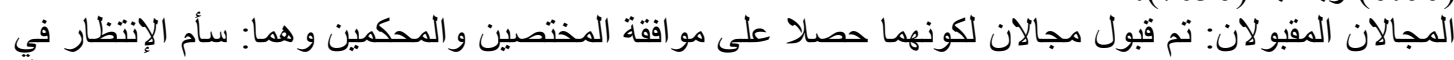

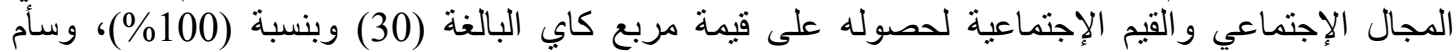

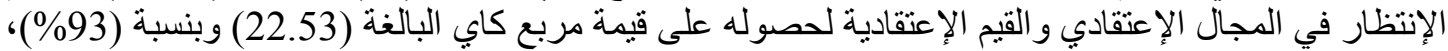

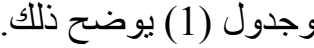
الجدول (1) آراء المحكمين والمختصين في صلاحية مجالات مقياس سأم الانتظار على وفق مربع كأي (Chi-square)

\begin{tabular}{|c|c|c|c|c|c|c|}
\hline \multirow{2}{*}{ 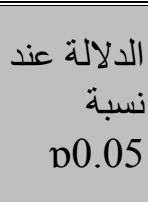 } & \multirow{2}{*}{$\begin{array}{r}\text { Chi- قيمة } \\
\text { square } \\
\text { المحسوبة }\end{array}$} & \multirow{2}{*}{ 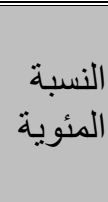 } & \multicolumn{2}{|c|}{ 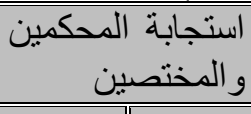 } & \multirow{2}{*}{ Field of Boredom waiting مجالات سأم الانتظار } & \multirow{2}{*}{ ت } \\
\hline & & & 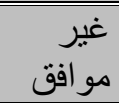 & مو افق & & \\
\hline دالة & 30 & $\% 100$ & 0 & 30 & وأقم الإنتظار في الإجماعة الإجتماعي & 1 \\
\hline غير دالة & 0.133 & $\% 53$ & 14 & 16 & و القيم الإنتصادي في المجال الاقتصنادي & 2 \\
\hline غير دالة & 3.33 & $\% 67$ & 10 & 20 & سأم الإنتظار في المجال المهني والقيم & 3 \\
\hline دالة & 22.53 & $\% 93$ & 2 & 28 & والقيم الإعتظادية في المجال الإعتقادي & 4 \\
\hline غير دالة & 0.133 & $\% 53$ & 14 & 16 & سأم الإنتظار في المجال الصحي و القيم & 5 \\
\hline غير دالة & 0.00 & $\% 50$ & 15 & 15 & والمتعلقات الإنتظار اسية في المجال الدراسي & 6 \\
\hline
\end{tabular}

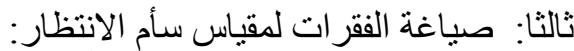

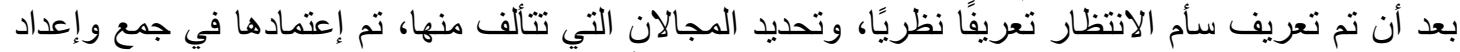

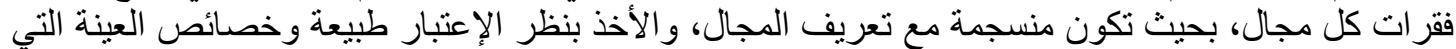

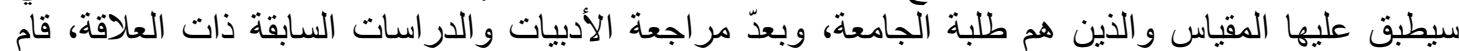

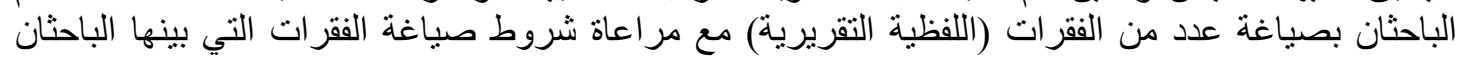

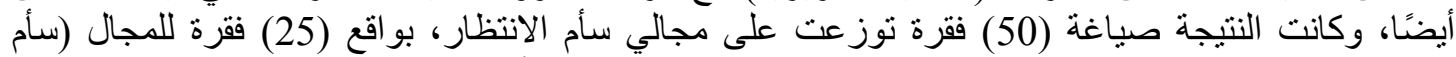

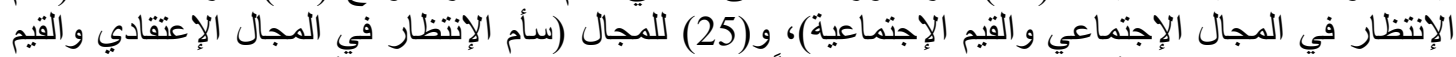

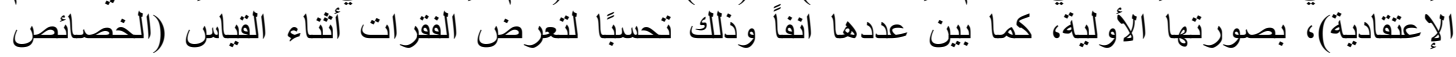

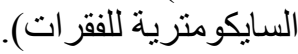
رابعا: صدق البناء لمقياس سأم الانتظار : وتمثل في الاجر اءات الآتية

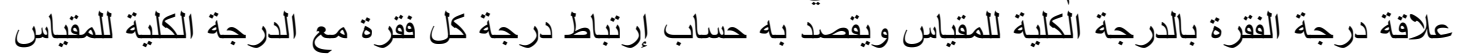

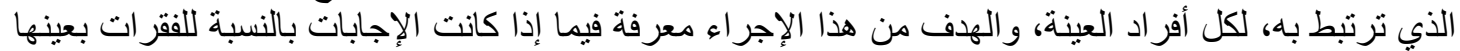




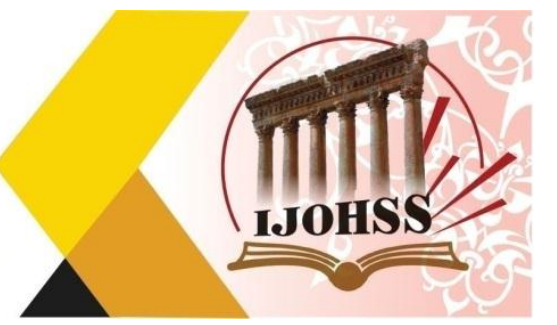

متسقة بطريقة معقولة مع إتجاهات السلوك أو الثخصية التي تفترضها الدرجات، وبذلك تستعمل الدرجة الكلية

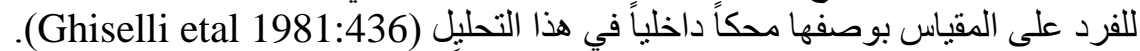

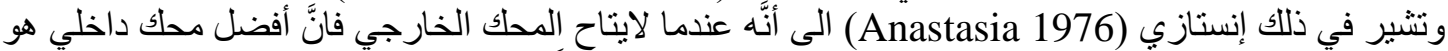

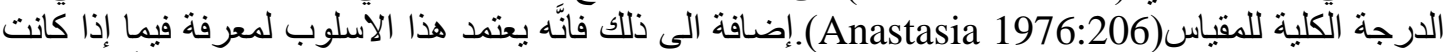

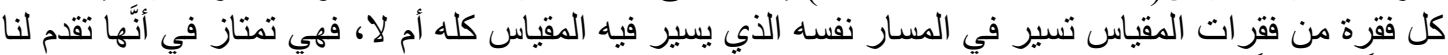

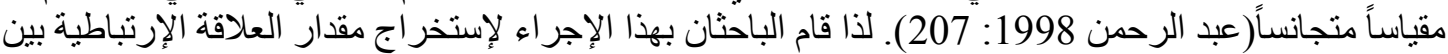

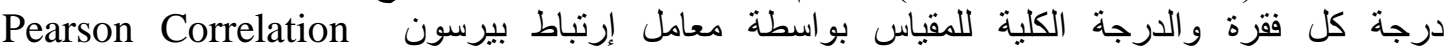
Coefficient

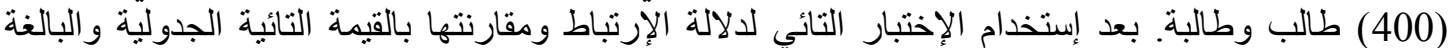

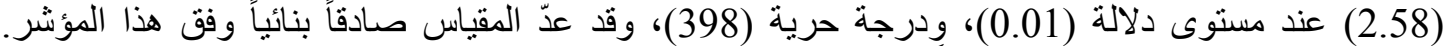

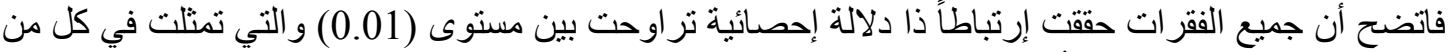

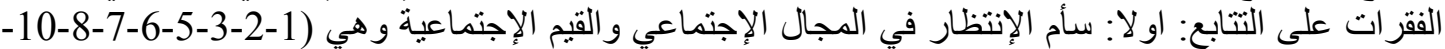

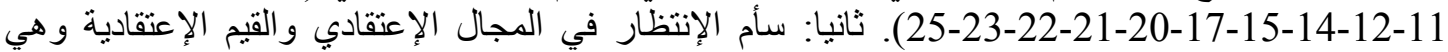
(الك (50-49-48-47-46-45-44-43-39-37-36-34-33-31-30-29-28-26). الموضح في جدول (2) يوضح الإنيا:

جدول (2) قيم معاملات الارتباط بين درجة الفقرة و الدرجة الكلية للمقياس والقيمة التائية للارتباط بالارجة باطن الكلية لمقياس سأم الانتظار

\begin{tabular}{|c|c|c|c|c|c|c|c|c|c|c|c|}
\hline \multicolumn{6}{|c|}{ سأم الإنتظال الإعتقادي و القبم الإعتقادية } & \multicolumn{6}{|c|}{ فئم الإنتظال الإجتماعي و القيم الإجتماعية } \\
\hline التائية - القية & العبلالدة & التائية & العبمة & رقة & ت & التائية & العلالداقة & التائية & العيمة & رق & ت \\
\hline $\begin{array}{r}16.4 \\
9\end{array}$ & 0.637 & 16.97 & 0.648 & 26 & $\begin{array}{l}1 \\
9\end{array}$ & 8.32 & 0.385 & 9.80 & 0.441 & 1 & 1 \\
\hline $\begin{array}{r}16.7 \\
5\end{array}$ & 0.643 & 16.57 & 0.639 & 28 & $\begin{array}{l}2 \\
0\end{array}$ & 7.31 & 0.344 & 9.91 & 0.445 & 2 & 2 \\
\hline $\begin{array}{r}17.1 \\
1\end{array}$ & 0.651 & 18.10 & 0.672 & 29 & $\begin{array}{l}2 \\
1\end{array}$ & 8.20 & 0.380 & 9.86 & 0.443 & 3 & 3 \\
\hline 8.66 & 0.398 & 10.17 & 0.454 & 30 & $\begin{array}{l}2 \\
2 \\
\end{array}$ & $\begin{array}{r}11.1 \\
8 \\
\end{array}$ & 0.489 & 13.48 & 0.560 & 5 & 4 \\
\hline $\begin{array}{r}16.7 \\
9\end{array}$ & 0.644 & 18.60 & 0.682 & 31 & $\begin{array}{l}2 \\
3\end{array}$ & $\begin{array}{r}11.1 \\
5\end{array}$ & 0.488 & 11.89 & 0.512 & 6 & 5 \\
\hline $\begin{array}{r}18.4 \\
5\end{array}$ & 0.679 & 19.55 & 0.700 & 33 & $\begin{array}{l}2 \\
4\end{array}$ & $\begin{array}{r}12.5 \\
7\end{array}$ & 0.533 & 13.52 & 0.561 & 7 & 6 \\
\hline $\begin{array}{r}14.2 \\
8\end{array}$ & 0.582 & 15.24 & 0.607 & 34 & $\begin{array}{l}2 \\
5\end{array}$ & 9.89 & 0.444 & 7.19 & 0.439 & 8 & 7 \\
\hline $\begin{array}{r}15.4 \\
4 \\
\end{array}$ & 0.612 & 16.31 & 0.633 & 36 & $\begin{array}{l}2 \\
6\end{array}$ & $\begin{array}{r}12.9 \\
3 \\
\end{array}$ & 0.544 & 13.35 & 0.556 & 10 & 8 \\
\hline
\end{tabular}


المجلة اللحولية اللملوم الآنسانية والامتماعية International Journal on Humanities and Social Sciences websiteawww.ijohss.com Email:editor@ijohss.com

العدد (28) ديسمبر 2021 ISSN: $2415-4822$

Volume (28) December 2021

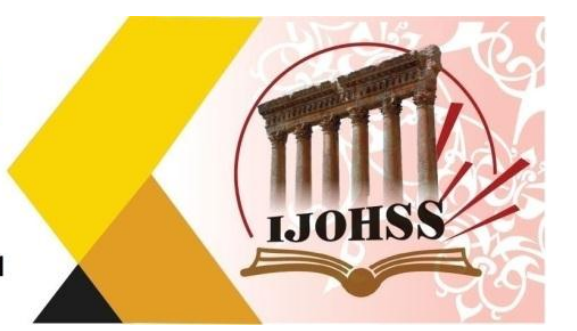

\begin{tabular}{|c|c|c|c|c|c|c|c|c|c|c|c|}
\hline $\begin{array}{r}11.9 \\
9 \\
\end{array}$ & 0.515 & 17.02 & 0.649 & 37 & $\begin{array}{l}2 \\
7 \\
\end{array}$ & $\begin{array}{r}14.8 \\
1 \\
\end{array}$ & 0.596 & 15.60 & 0.616 & 11 & 9 \\
\hline $\begin{array}{r}12.6 \\
0\end{array}$ & 0.534 & 14.35 & 0.584 & 39 & $\begin{array}{l}2 \\
8\end{array}$ & 8.48 & 0.391 & 10.34 & 0.460 & 12 & $\overline{10}$ \\
\hline $\begin{array}{r}12.0 \\
8\end{array}$ & 0.518 & 13.04 & 0.547 & 43 & $\begin{array}{l}2 \\
9\end{array}$ & $\begin{array}{r}14.0 \\
6\end{array}$ & 0.576 & 15.44 & 0.612 & 14 & $\overline{11}$ \\
\hline $\begin{array}{r}14.2 \\
0\end{array}$ & 0.580 & 15.93 & 0.624 & 44 & 0 & $\begin{array}{r}14.0 \\
6\end{array}$ & 0.576 & 15.24 & 0.607 & 15 & 12 \\
\hline $\begin{array}{r}16.7 \\
1\end{array}$ & 0.642 & 17.81 & 0.666 & 45 & $\begin{array}{l}3 \\
1\end{array}$ & $\begin{array}{r}13.0 \\
4\end{array}$ & 0.547 & 13.98 & 0.574 & 17 & 13 \\
\hline $\begin{array}{r}15.8 \\
9 \\
\end{array}$ & 0.623 & 17.29 & 0.655 & 46 & $\begin{array}{l}3 \\
2 \\
\end{array}$ & $\begin{array}{r}15.1 \\
2 \\
\end{array}$ & 0.604 & 13.73 & 0.567 & 20 & 14 \\
\hline $\begin{array}{r}12.2 \\
1 \\
\end{array}$ & 0.522 & 13.73 & 0.567 & 47 & $\begin{array}{l}3 \\
3 \\
\end{array}$ & $\begin{array}{r}12.2 \\
7 \\
\end{array}$ & 0.524 & 12.21 & 0.522 & 21 & 15 \\
\hline $\begin{array}{r}15.6 \\
0 \\
\end{array}$ & 0.616 & 18.50 & 0.680 & 48 & $\begin{array}{l}3 \\
4 \\
\end{array}$ & $\begin{array}{r}14.5 \\
0 \\
\end{array}$ & 0.588 & 14.17 & 0.579 & 22 & 16 \\
\hline $\begin{array}{r}15.9 \\
3 \\
\end{array}$ & 0.624 & 17.43 & 0.658 & 49 & $\begin{array}{l}3 \\
5 \\
\end{array}$ & $\begin{array}{r}15.0 \\
8 \\
\end{array}$ & 0.603 & 15.60 & 0.616 & 23 & 17 \\
\hline $\begin{array}{r}18.7 \\
1\end{array}$ & 0.684 & 18.25 & 0.675 & 50 & $\begin{array}{l}3 \\
6\end{array}$ & $\begin{array}{r}15.0 \\
0\end{array}$ & 0.601 & 14.62 & 0.591 & 25 & 18 \\
\hline
\end{tabular}

خامسا: الخصائص السايكومنرية لمقياس سأم الإنتظار :

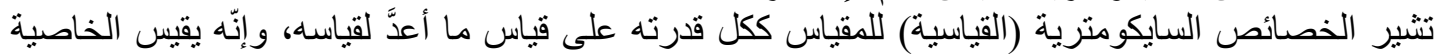

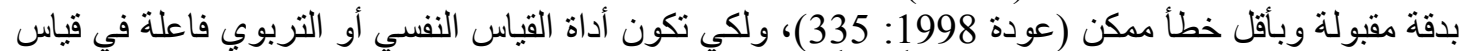

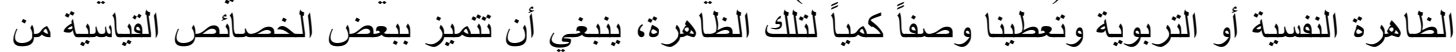
أهمها الصدق و الثبات (الإمام و آخرون 1990: 241)،وقد نم التحقق من هاتين الخاصيتين لمقياس سأم الإنتظار

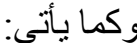
1- مؤشرات صدق المقياس (Validity Scale):يعد الصدق من أهم الخصائص السايكومترية التي ينبغي

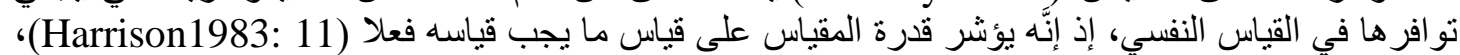

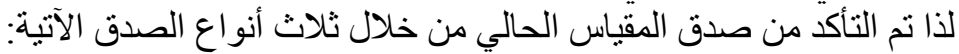

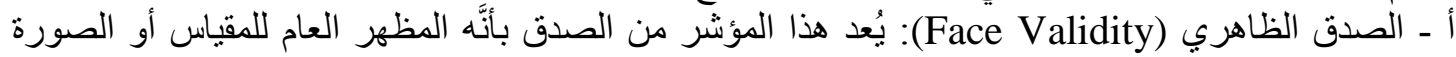

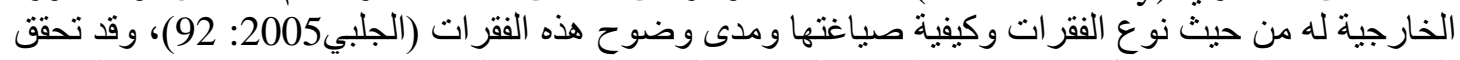

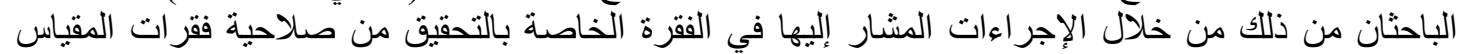

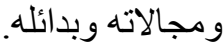
ب- صدق البناء (Construct validity):ويعني تحليل درجات الدياء المقياس إستناداً إلى البناء النفسي للخاصية

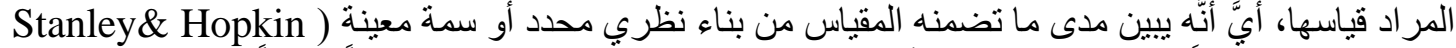

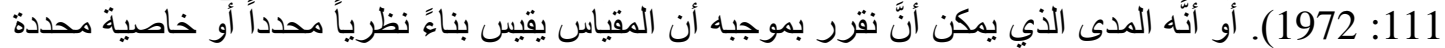

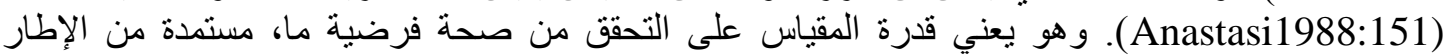

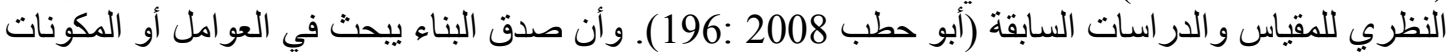

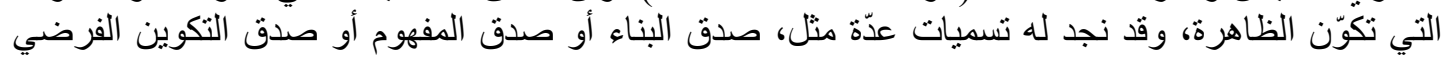




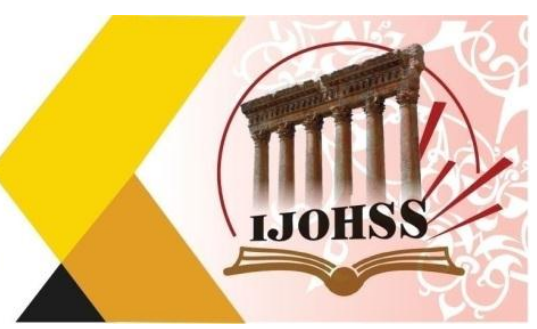

(Anastasi \&Urbina ,1997: 126 وقد تم التحقق من صدق البناء للمقياس الحالي من خلال

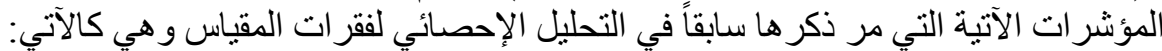

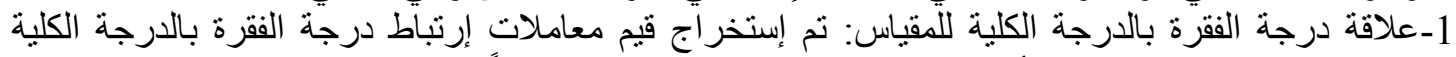

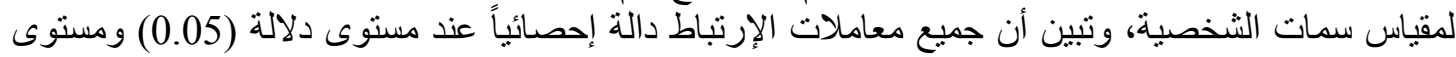

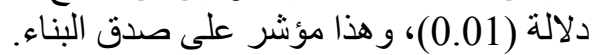

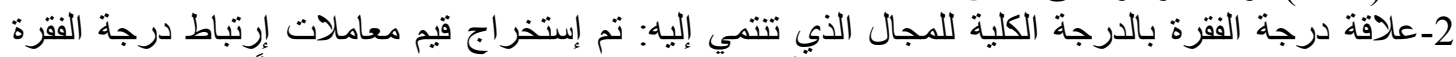

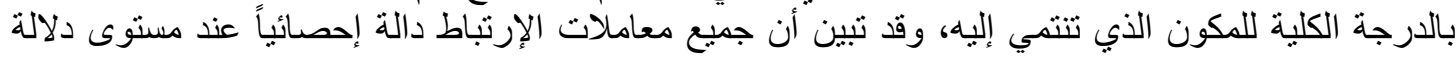

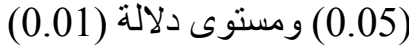

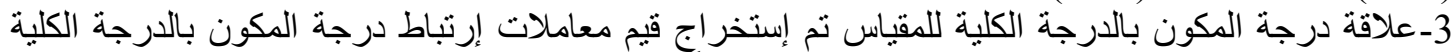

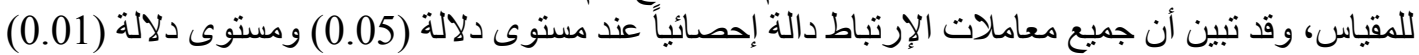
ج - الصدق العاملي (Factorial Validity):

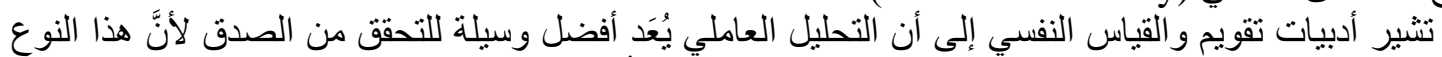

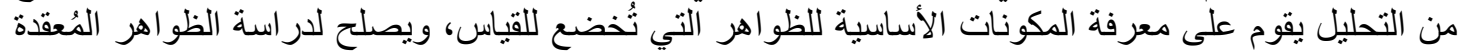

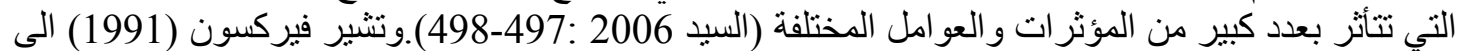

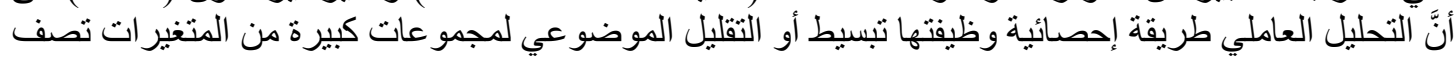

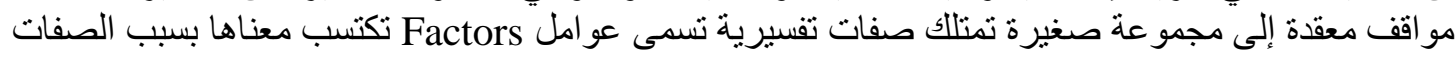

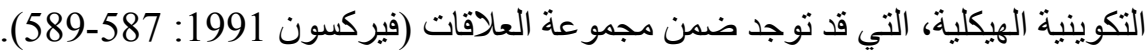

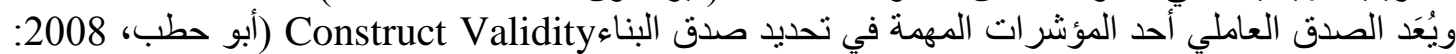

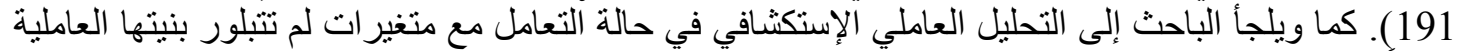

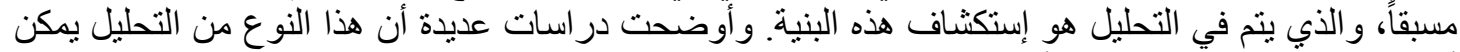

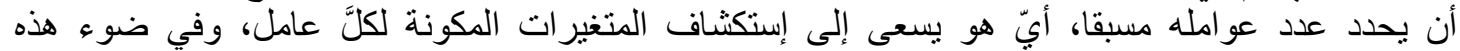

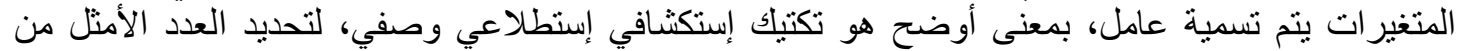

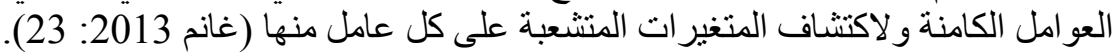

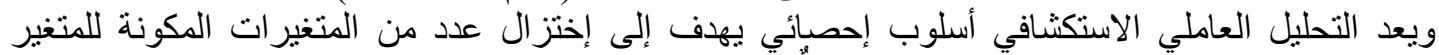

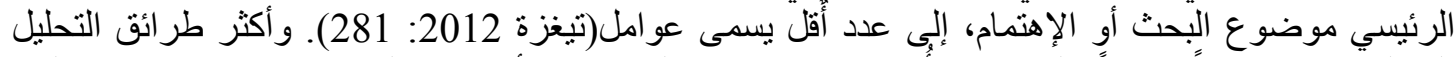

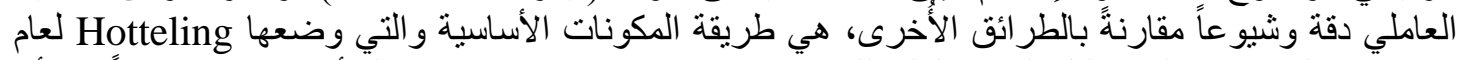

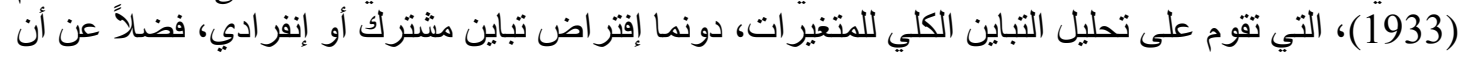

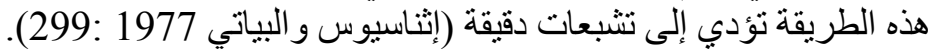

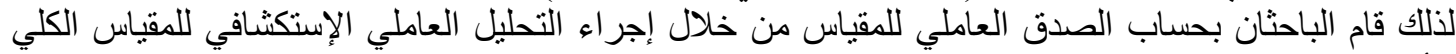

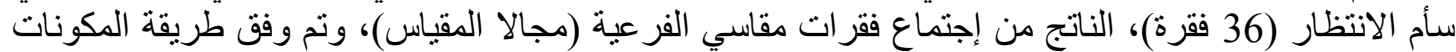

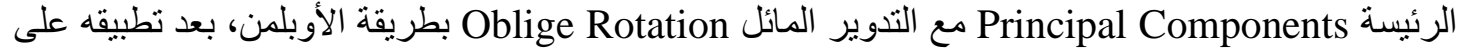

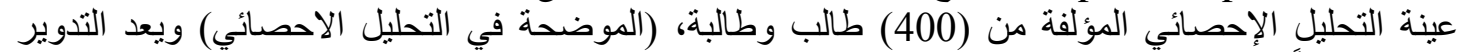

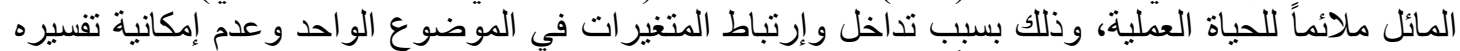

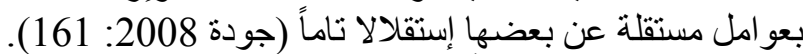

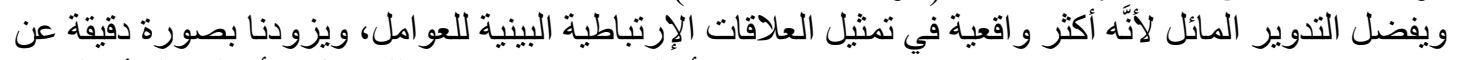

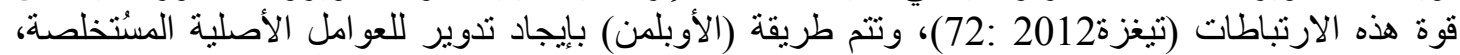

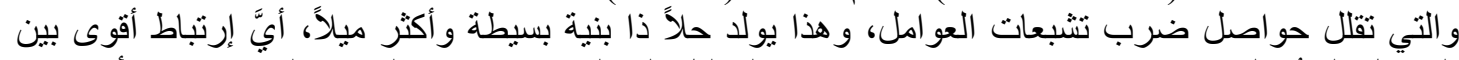

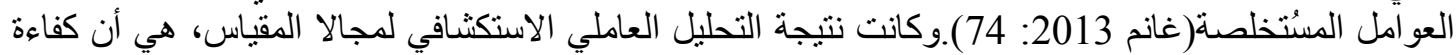

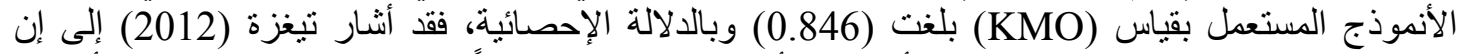

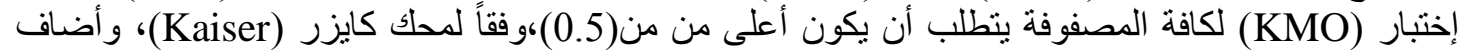

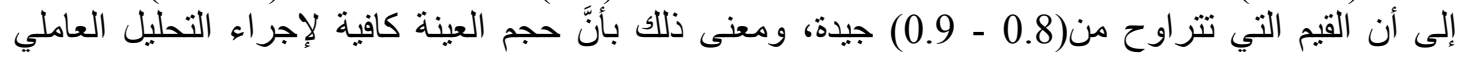

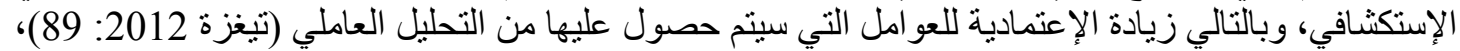

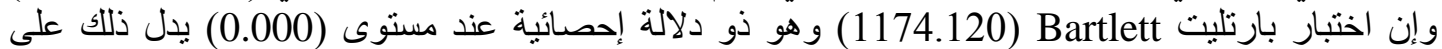


المجلة اللحولية اللملوم الآنسانية والامتماعية International Journal on Humanities and Social Sciences website:www.ijohss.com Email:editor@ijohss.com

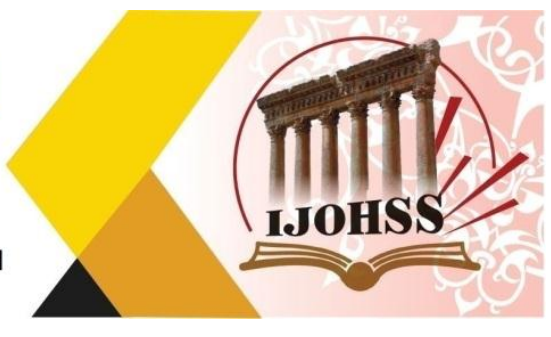

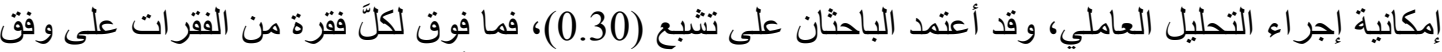

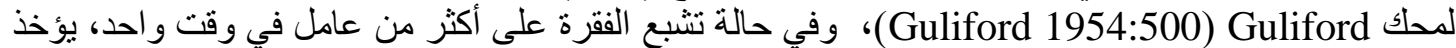

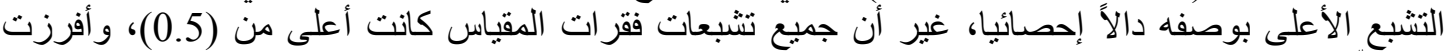

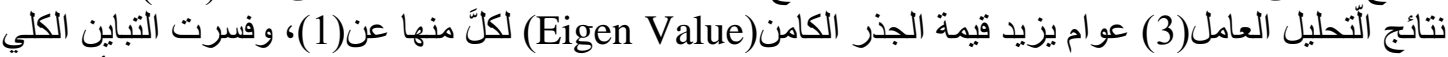

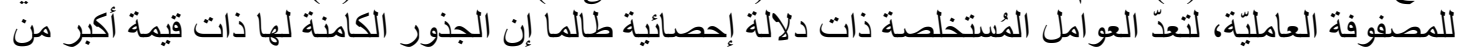

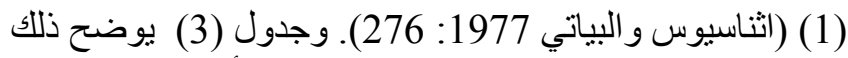

جلول (3) نتائج التحليل العاملي لمقياس سأم الانتظار وتثثبعات فقراته بالعاملين (الاجتماعي و العقائدي)

\begin{tabular}{|c|c|c|c|c|c|c|c|}
\hline \multirow[t]{2}{*}{ قيم الثيوع } & \multicolumn{2}{|c|}{ بعد التدوير } & \multicolumn{2}{|c|}{ قبل التدوير } & \multirow{2}{*}{ رقلم } & \multirow{2}{*}{$ت$} & \multirow{2}{*}{ المقياس } \\
\hline & العامل2 & العامل1 & العامل2 & العامل1 & & & \\
\hline 0.470 & & 0.596 & & 0.452 & 1 & & \multirow{18}{*}{ 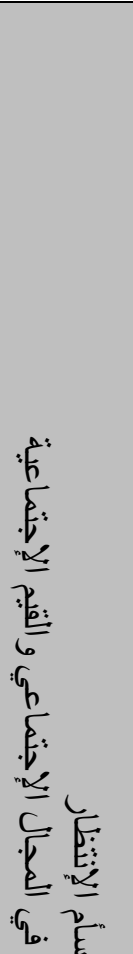 } \\
\hline 0.549 & & 0.601 & & 0.457 & 2 & & \\
\hline 0.613 & & 0.674 & & 0.53 & 3 & & \\
\hline 0.652 & & 0.625 & & 0.481 & 5 & & \\
\hline 0.675 & & 0.722 & & 0.578 & 6 & & \\
\hline 0.647 & & 0.68 & & 0.536 & 7 & & \\
\hline 0.678 & & 0.687 & & 0.543 & 8 & & \\
\hline 0.535 & & 0.694 & & 0.55 & 10 & & \\
\hline 0.447 & & 0.652 & & 0.508 & 11 & & \\
\hline 0.588 & & 0.663 & & 0.519 & 12 & & \\
\hline 0.643 & & 0.685 & & $\overline{0.541}$ & 14 & & \\
\hline 0.580 & & 0.66 & & 0.516 & 15 & & \\
\hline 0.401 & & 0.566 & & 0.422 & 17 & & \\
\hline 0.698 & & 0.732 & & 0.588 & 20 & & \\
\hline 0.647 & & 0.746 & & 0.602 & 21 & & \\
\hline 0.589 & & 0.692 & & 0.548 & 22 & & \\
\hline 0.676 & & 0.473 & & 0.329 & 23 & & \\
\hline 0.506 & & 0.495 & & 0.351 & 25 & & \\
\hline 0.445 & 0.301 & & 0.545 & & 26 & & \multirow{12}{*}{ 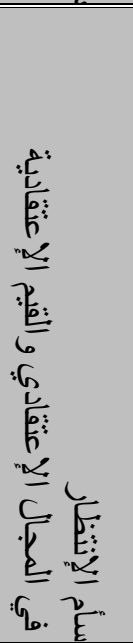 } \\
\hline 0.469 & 0.316 & & 0.585 & & 28 & & \\
\hline 0.493 & 0.349 & & 0.584 & & 29 & & \\
\hline 0.483 & 0.339 & & 0.336 & & 30 & & \\
\hline 0.527 & 0.383 & & 0.585 & & 31 & & \\
\hline 0.385 & 0.241 & & 0.540 & & 33 & & \\
\hline 0.396 & 0.246 & & 0.418 & & 34 & & \\
\hline 0.463 & 0.319 & & 0.489 & & 36 & & \\
\hline 0.414 & 0.27 & & 0.661 & & 37 & & \\
\hline 0.511 & 0.367 & & 0.458 & & 39 & & \\
\hline 0.469 & 0.325 & & 0.583 & & 43 & & \\
\hline 0.476 & 0.332 & & 0.501 & & 44 & & \\
\hline
\end{tabular}




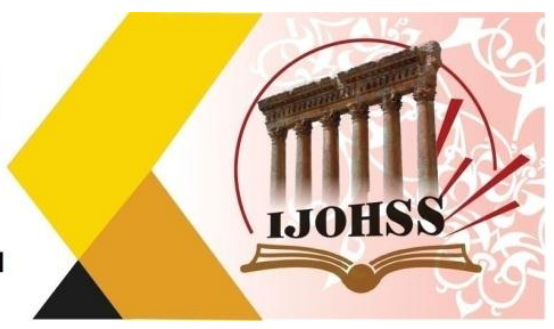

\begin{tabular}{|c|c|c|c|c|}
\hline 0.483 & 0.339 & & 0.593 & 45 \\
\hline 0.441 & 0.297 & & 0.582 & $\overline{466}$ \\
\hline 0.452 & 0.308 & & 0.482 & 47 \\
\hline 0.408 & 0.264 & & 0.568 & 48 \\
\hline 0.514 & 0.37 & & 0.554 & 49 \\
\hline 0.515 & 0.366 & & 0.614 & $\overline{50}$ \\
\hline & $\begin{array}{r}16.21 \\
0 \\
\end{array}$ & 2.521 & \multicolumn{2}{|c|}{ لتباين التراكمي } \\
\hline & 4.018 & 4.422 & \multicolumn{2}{|c|}{ التباين المفسر } \\
\hline
\end{tabular}

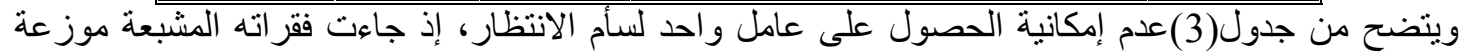

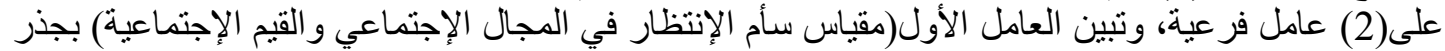

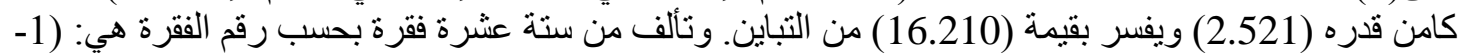

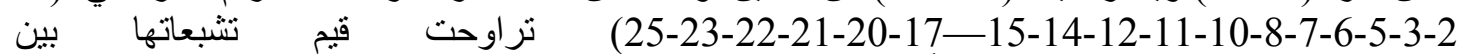

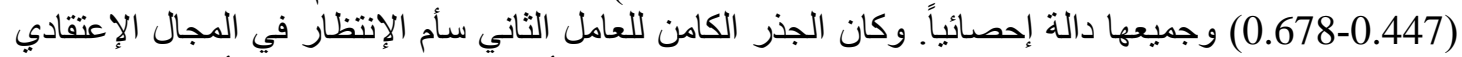

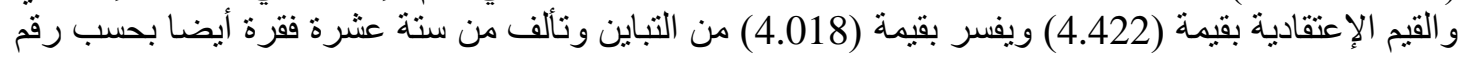

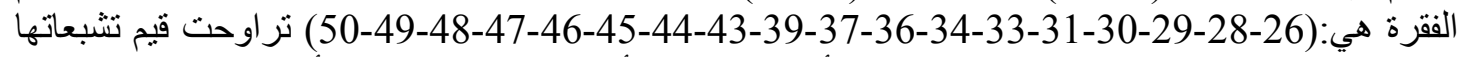

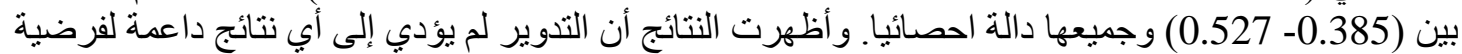

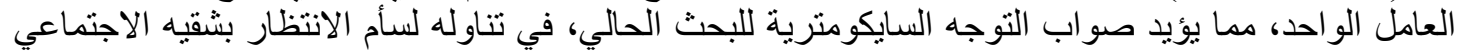

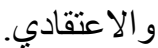

سادسا: مؤشر ات ثبات المقياس (Reliability Scale)

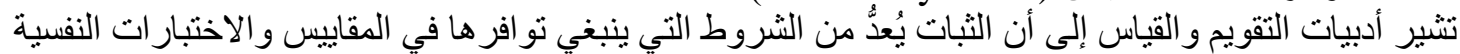

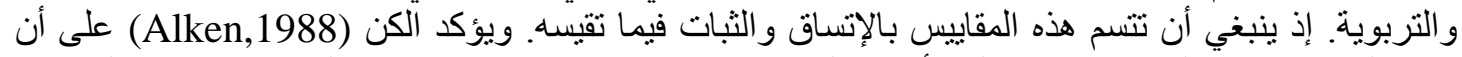

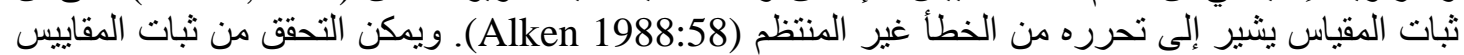
والإختبار ات النفسية بطر ائق عدة، منها:

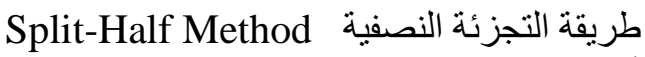

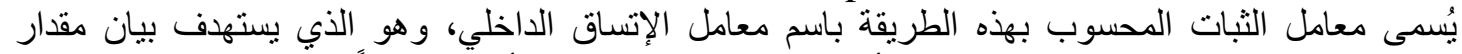

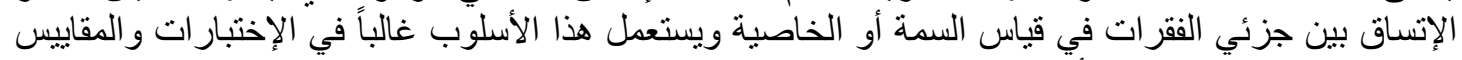

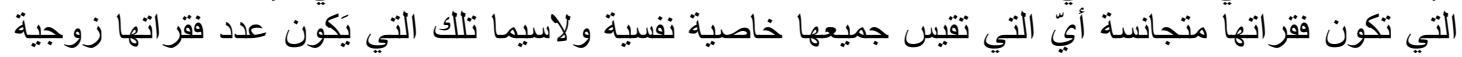

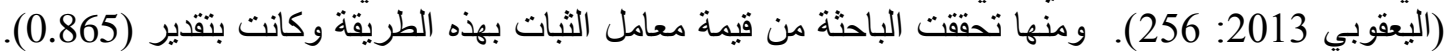

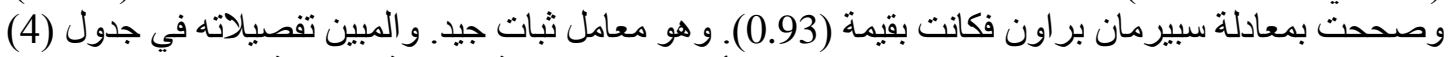
جدول (4) نتائج الثبات لمقياس سأم الانتظار بطريقة التجزئة النصفية

\begin{tabular}{|c|c|c|}
\hline درجة الثبات & 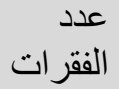 & المجال او الكمون \\
\hline 0.717 & 18 & الإجتماعية سأم الإنتظار في المجال الإجتماعي و القيم \\
\hline 0.843 & 18 & الإعتقادية سأم الإنتظار في المجال الإعتقادي و القيم \\
\hline 0.865 & 36 & المقياس ككل \\
\hline
\end{tabular}




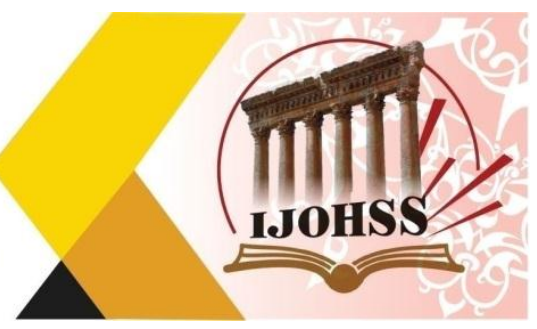

طريقة الفا كرونباخ (Cronbach Alpha):

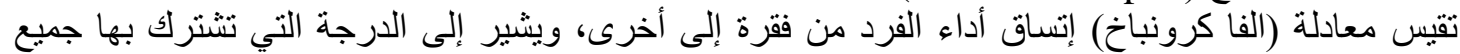

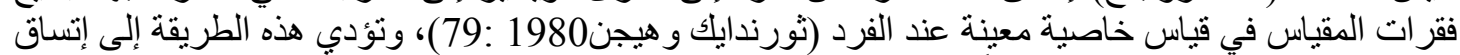

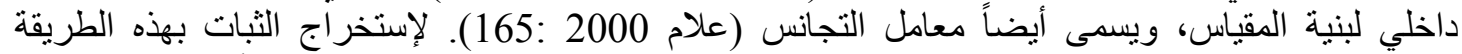

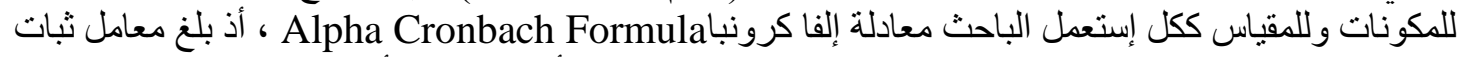

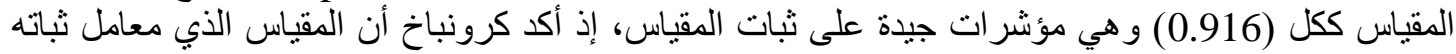

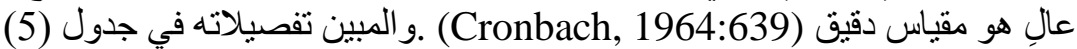
جلول (5) نتائج الثبات لمقياس سأم الانتظار بطريقة الفا كرونباخ

\begin{tabular}{|c|c|c|}
\hline درجة الثبات & الفقر ات & 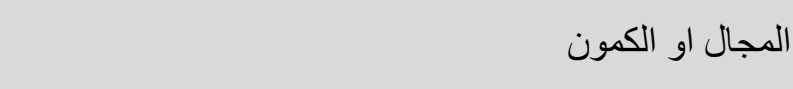 \\
\hline 0.807 & 18 & المجال سأم الإنتظار في المجال الإجتماعي و القيم الإجتماعية \\
\hline 0.889 & 18 & المجال سأم الإنتظار في المجال الإعتقادي و القيم الإعتقادية \\
\hline 0.916 & 36 & المقياس ككل \\
\hline
\end{tabular}

سابعا: المؤشر ات الإحصائية لمقياس سأم الانتظار:

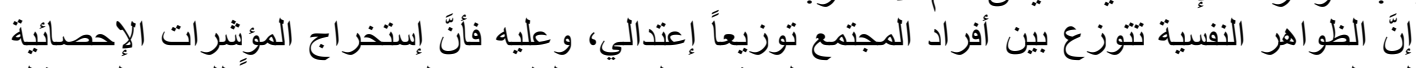

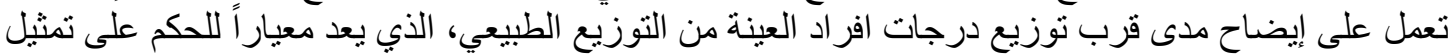

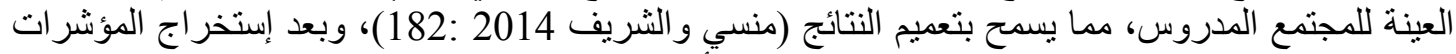

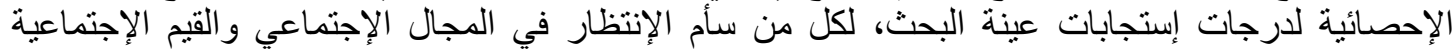

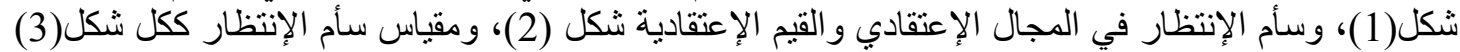

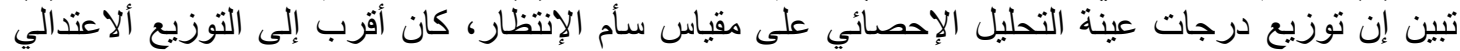
Normal Distribution جدول (6) يوضح المؤشرات الإحصائية لمقياس سأم الانتظار الإن الإنظار

\begin{tabular}{|c|c|c|c|c|}
\hline 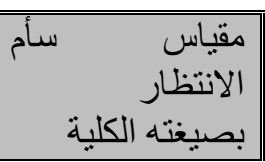 & فأم الإنتظار $\quad$ والقيم الإعتقادي & وأم الإنتظار الإجنماعي الإجناع & $\begin{array}{r}\text { المؤشرات الإحصائية } \\
\text { Statistics }\end{array}$ & ت \\
\hline 400 & 400 & 400 & n Valid & \\
\hline 134.30 & 68.08 & 66.22 & Mean & \\
\hline 1.085 & 0.620 & 0.532 & Std. Error of Mean & \\
\hline 137.00 & 70.00 & 67.00 & Median & \\
\hline 142 & 72 & 70 & Mode & \\
\hline 21.694 & 12.402 & 10.647 & Std. Deviation & \\
\hline $0.842-$ & $0.792-$ & $0.778-$ & Skewness & \\
\hline 0.122 & 0.122 & 0.122 & $\begin{array}{ll}\text { Std. } & \text { Error of } \\
& \text { Skewness }\end{array}$ & \\
\hline 1.475 & 1.163 & 1.179 & Kurtosis & \\
\hline 0.243 & 0.243 & 0.243 & $\begin{array}{r}\text { Error of } \\
\text { Kurtosis } \\
\end{array}$ & \\
\hline 36 & 18 & 18 & Minimum & \\
\hline 180 & 90 & 90 & Maximum & \\
\hline 53719 & 27232 & 26487 & Total scores & \\
\hline
\end{tabular}



International Journal on Humanities and Social Sciences website:www.ijohss.com Email:editor@ijohss.com العدد (28) ديسمبر 2021 ISSN: $2415-4822$

Volume (28) December 2021
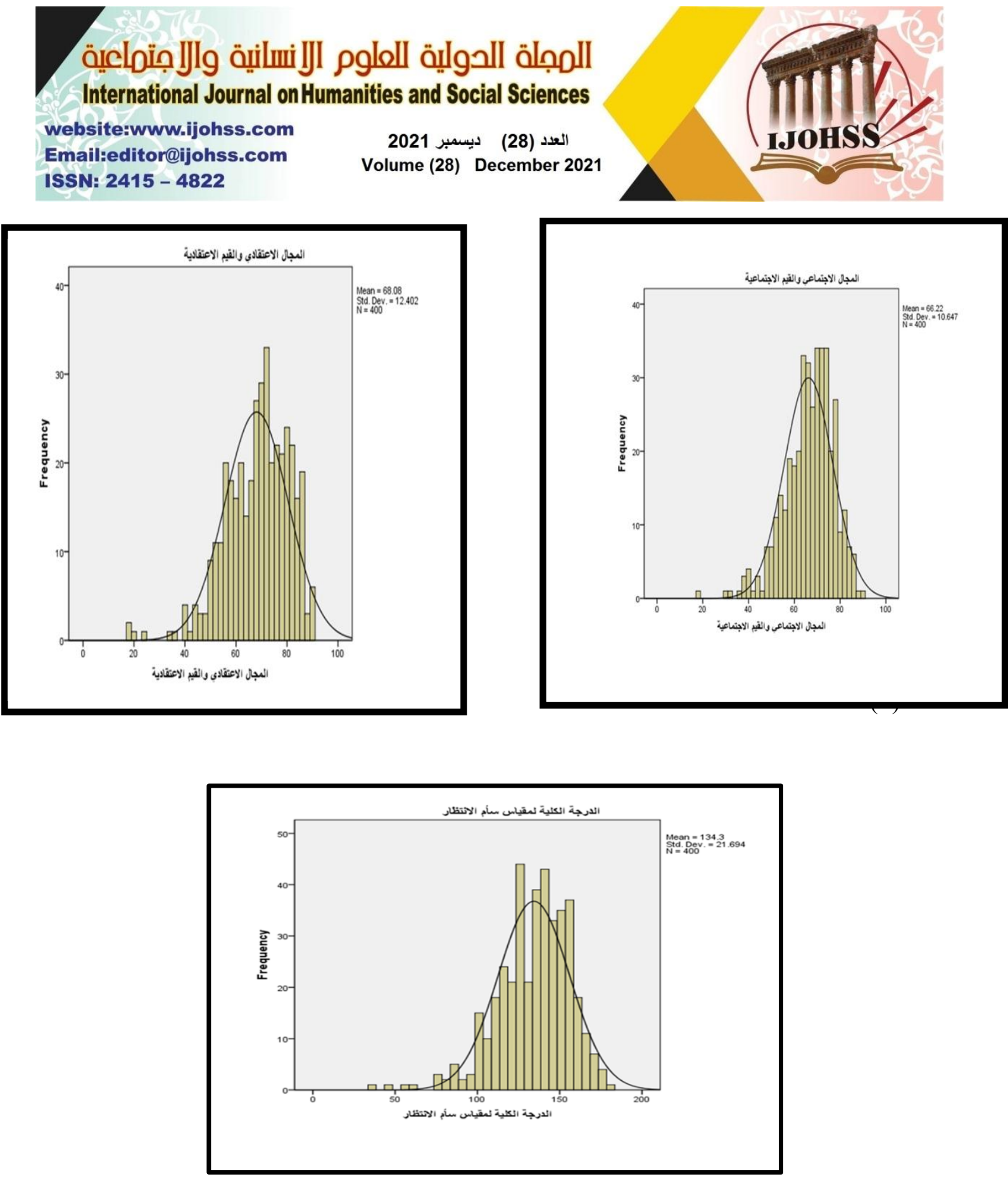

شكل (3)

ثامنا: وصف مقياس سأم الإنتظار بصيغته النهائية:

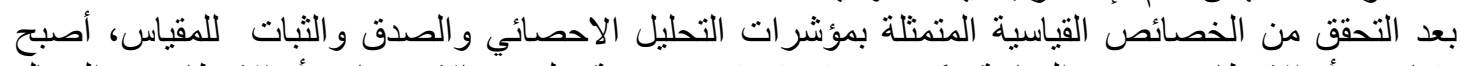

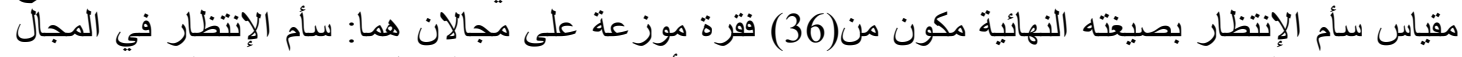

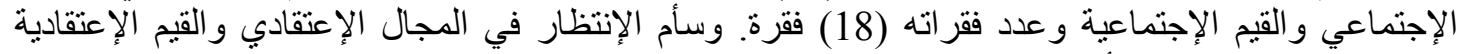

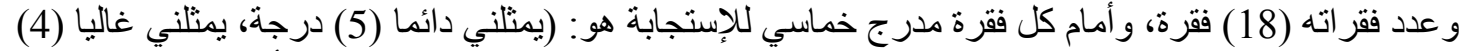

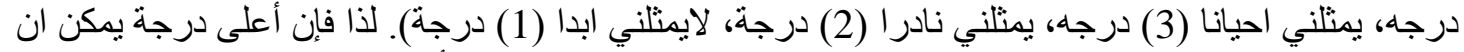

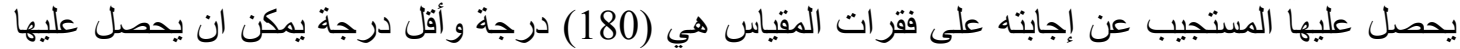

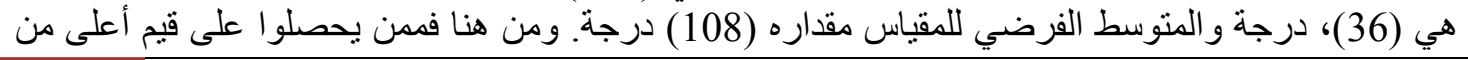




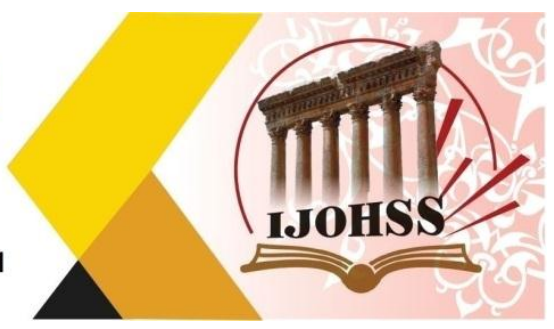

(108) يتمتعون بسأم الإنتظار ، والذين يحصلو البنا على قيم أقل من (108) فهم ليس لايهم سأم للانتظار وبذلك أصبح المقياس جاهز ا للتطبيق على عينة البحث الأنساسية.

خامسا: التطبيق النهائي للمقاييس:

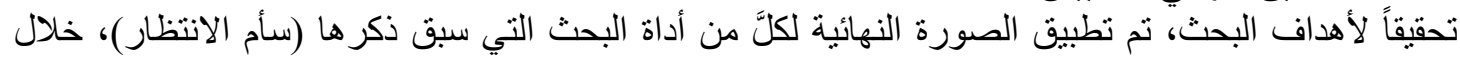

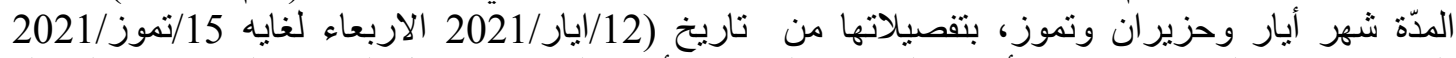

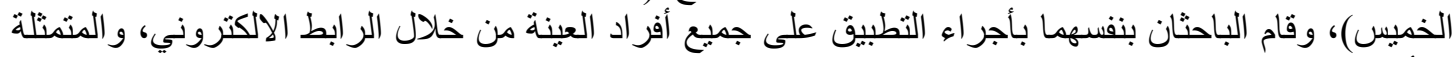

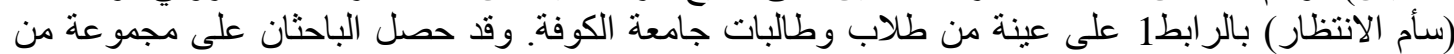

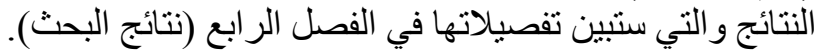

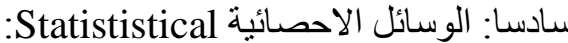
تم استخدام الوسائل الاحصائية بواسطة الحقيبة الاحصائية للعلوم الاجتماعية (SPSS) الإصدار (V.25) وبحسب ترتيب استعمالها في البحث البنة

\section{الفصل الرابع تفسير النتائج :}

يتضمن هذا الفصل عرضًا للنتائج التي تم التوصل اليها على وفق أهداف البحثث وتفسير هذه النتائج ومناقتنتها

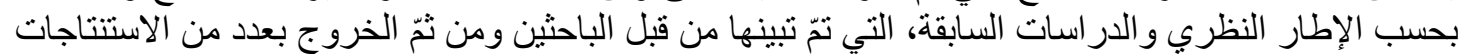

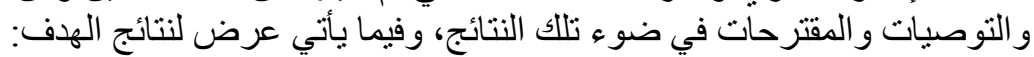

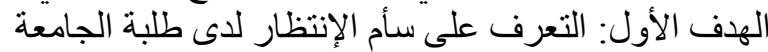

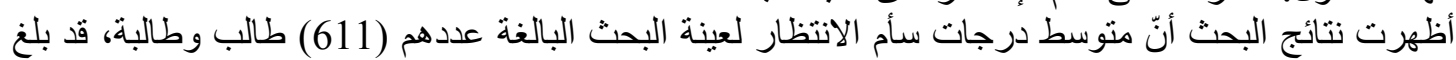

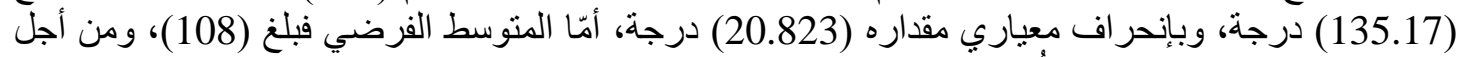

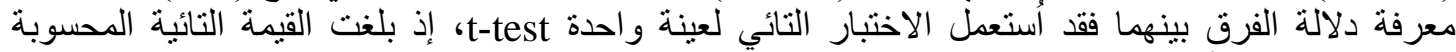

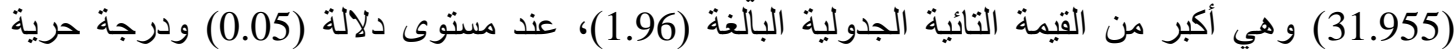
(610)، و هذه النتيجة تشير إلى أنّ طلبة جامعة الكوفة يعانون من سأم الانتظار، بحسب البئة البيانات المتوفرة في

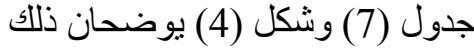

جدول (7) الاختبار التائي الإختبار التائي (t-test) على مقياس سأم الانتظار لاى طلبة جامعة الكوفة

\begin{tabular}{|c|c|c|c|c|c|c|c|c|}
\hline \multirow{2}{*}{ مستوى } & \multicolumn{2}{|c|}{ القيمة التائية } & \multirow{2}{*}{ الحرجة } & \multirow{2}{*}{ الفرضي } & \multirow{2}{*}{ الالانحراف } & \multirow{2}{*}{ الحسابي } & \multirow{2}{*}{ العينة } & \multirow{2}{*}{ المتغير } \\
\hline & الجدولية & بة المحسو & & & & & & \\
\hline $\begin{array}{r}0.05 \\
\text { دالة }\end{array}$ & 1.96 & 31.955 & 610 & 108 & 20.823 & 135.17 & 611 & سأنتطار \\
\hline
\end{tabular}



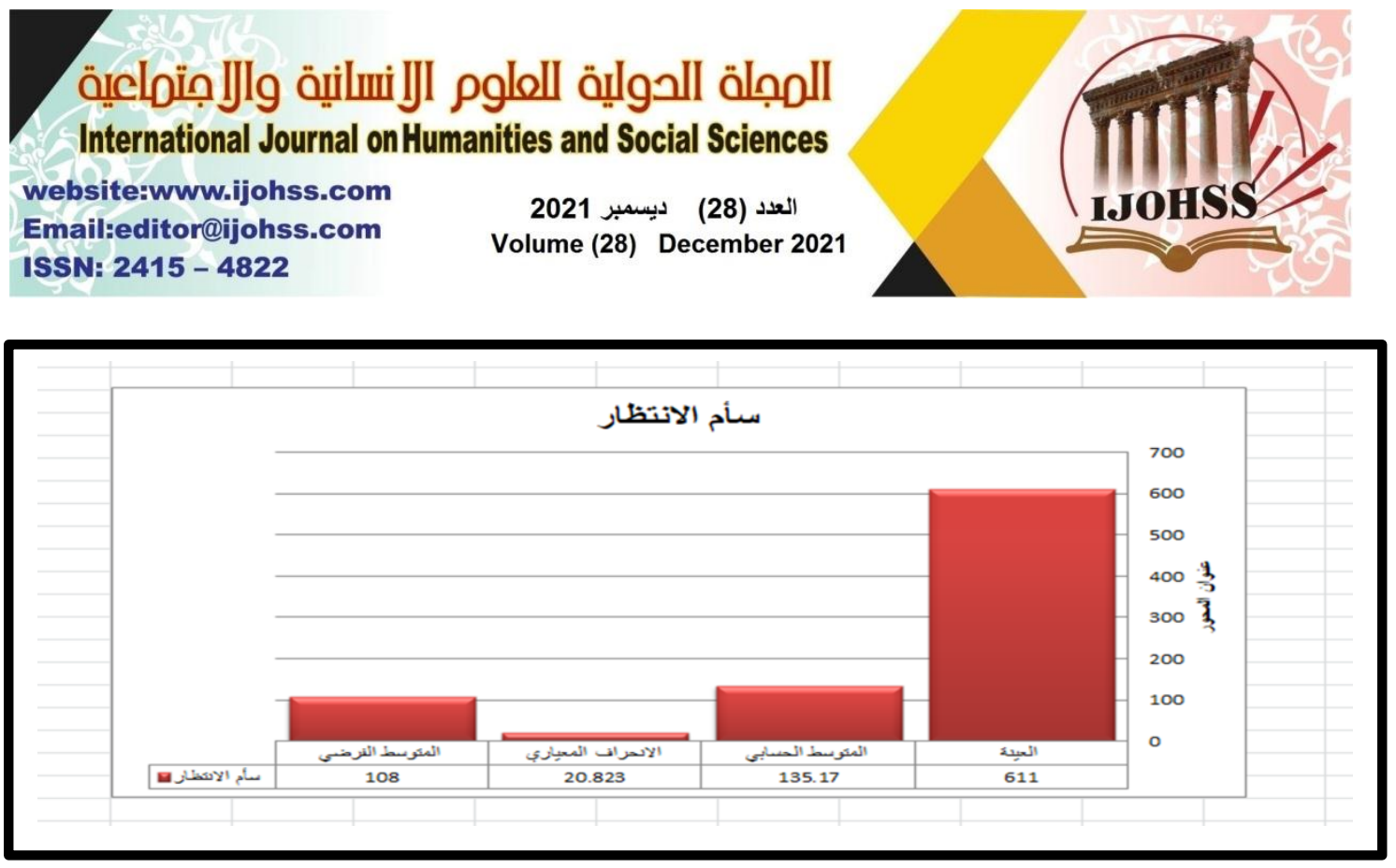

شكل (4) المقارنة بين الوسط الحسابي والفرضي للقياس

لارجات أفراد عينة البحث على مقياس سأم الانتظار لاى طلبة جامعة الكوفة

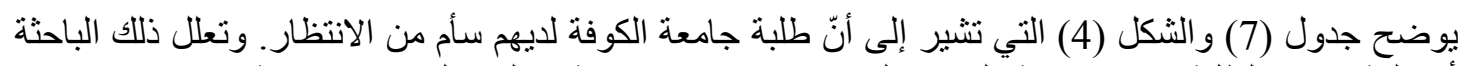

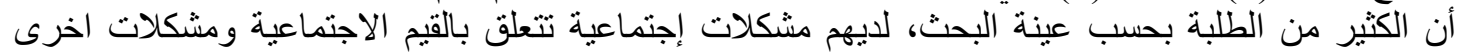

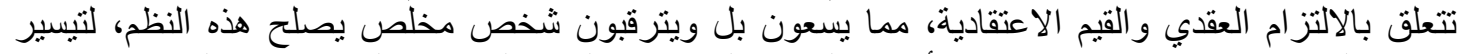

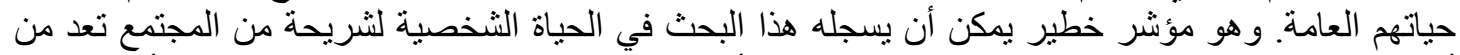

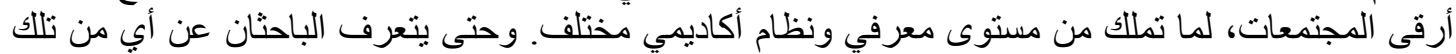

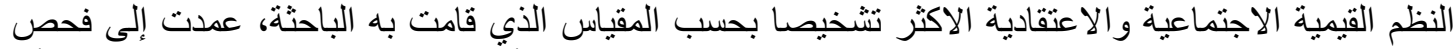

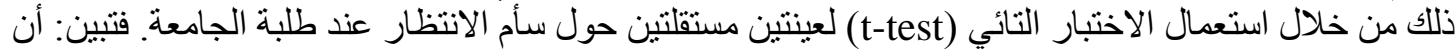

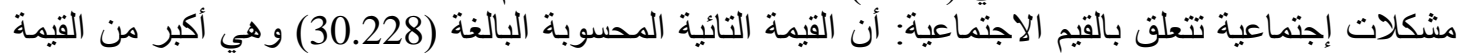

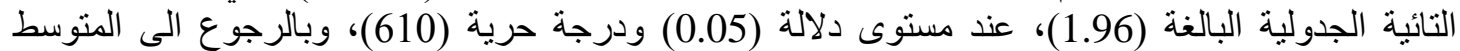

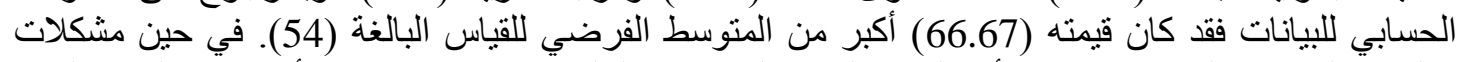

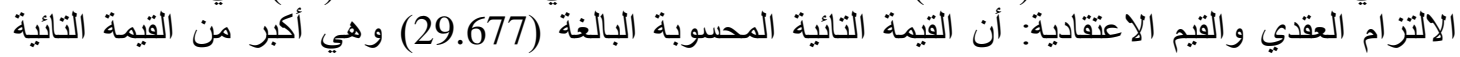

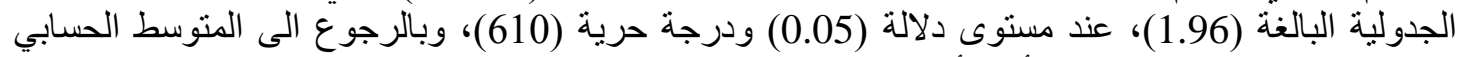

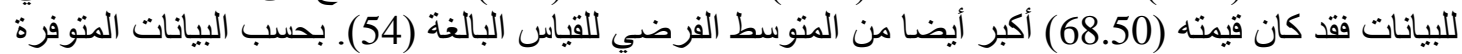

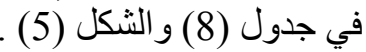
جدول (8) الاختبار التائي الإختبار التائي (t-test) لعينتين مستقلتين على مقياس سأم الانتظار (الاجتماعية والعقدية) لاى طلبة جامعة الكوفة لإنة

\begin{tabular}{|c|c|c|c|c|c|c|c|c|}
\hline \multirow{2}{*}{ الدلالة } & \multicolumn{2}{|c|}{ القيمة التائية } & \multirow{2}{*}{ ية } & \multirow{2}{*}{ الفرضي } & \multirow{2}{*}{ المعياري النحر } & \multirow{2}{*}{ الحسابي } & \multirow{2}{*}{ العينة } & \multirow{2}{*}{ سأم الانتظار } \\
\hline & الجدولية & المحسوبة & & & & & & \\
\hline \multirow{2}{*}{ د } & \multirow{2}{*}{1.96} & 30.228 & \multirow{2}{*}{610} & 54 & 10.263 & 66.67 & \multirow{2}{*}{611} & بالقيم الاجتماعية إجتماعية تتعلق \\
\hline & & 29.677 & & 54 & 11.968 & 68.50 & & مشكلات الالتز ام العقادية \\
\hline
\end{tabular}



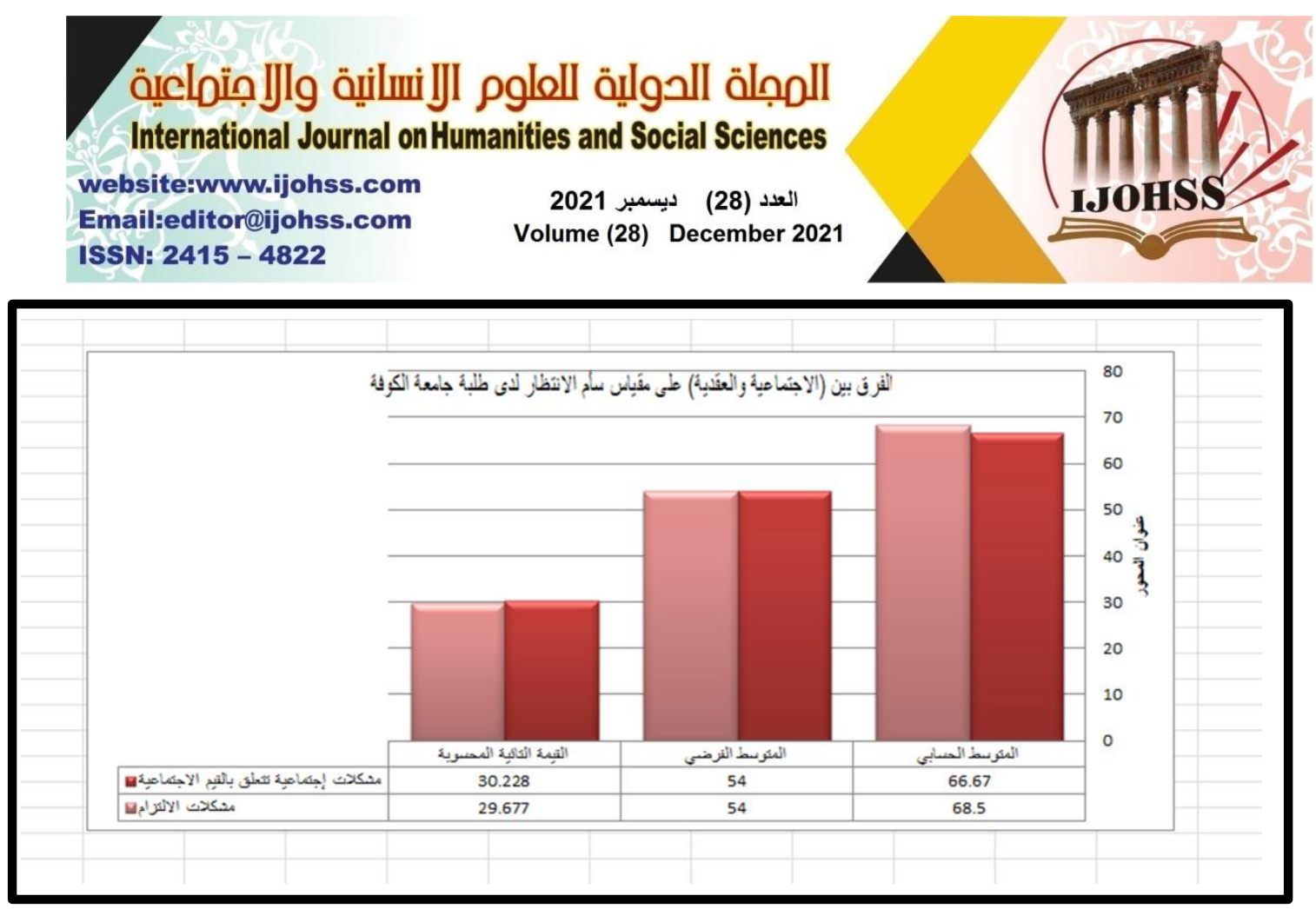

شكل (8) الفرق بين (الاجتماعية والعقدية) على مقياس سأم الانتظار لاى طلبة جامعة الكوفة

الهدف الثناني: الدلالة الاحصائية للفروق في سأم الانتظار لاى طلبة الجامعة على وفق متغير (النوع الاجتماعي،

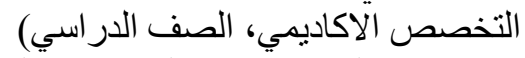

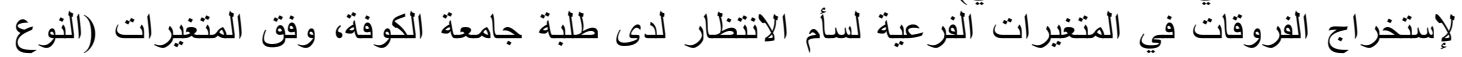

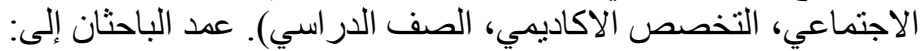

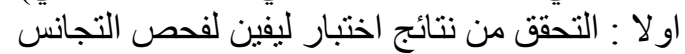

Levene's Test of Equality of Error Variances

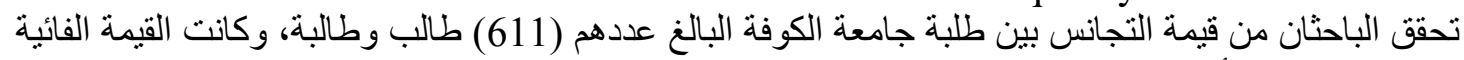

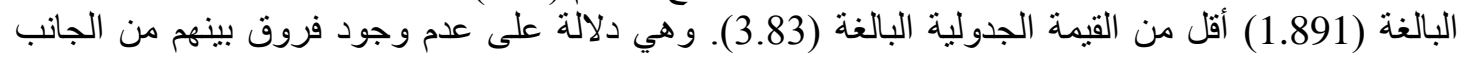

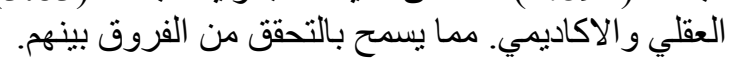
ثانيا: تحليل التباين الثناثي بالتفاعل (Three Way ANOVA)

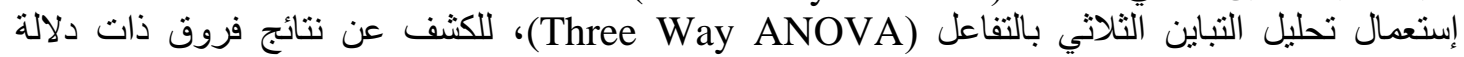

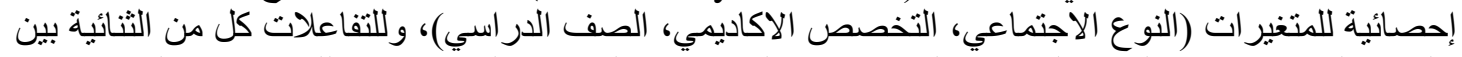

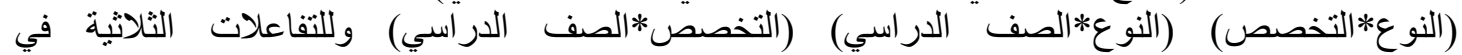

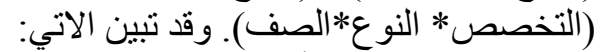
او لا: القيم الدالة عن سأم الانتظار :

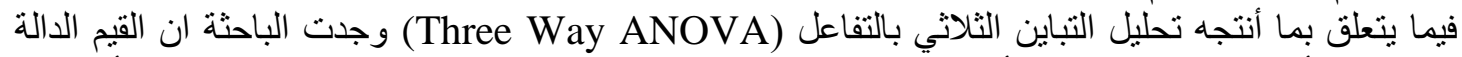

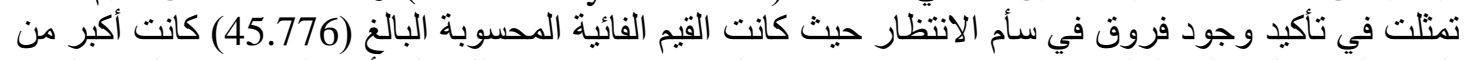

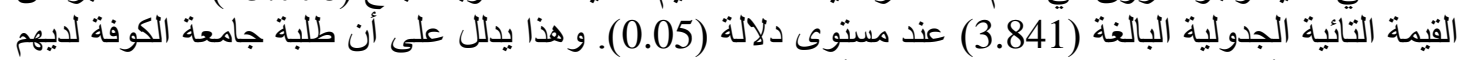

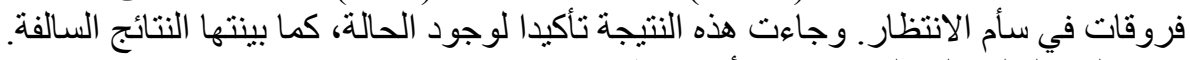

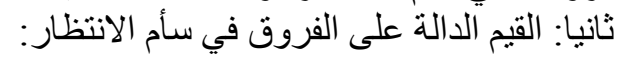

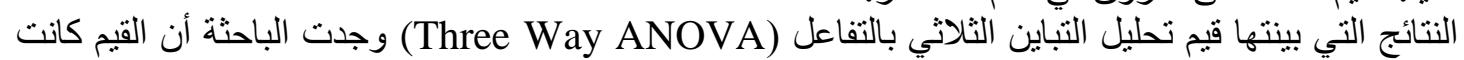

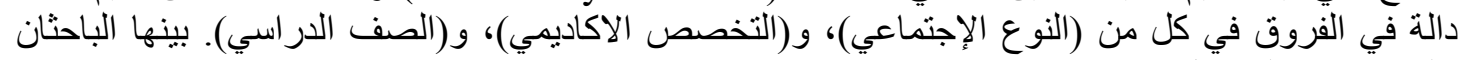
على نحو من التفصيل: الفروق الدالة إحصائيا في متغير النوع الإجتماعي 


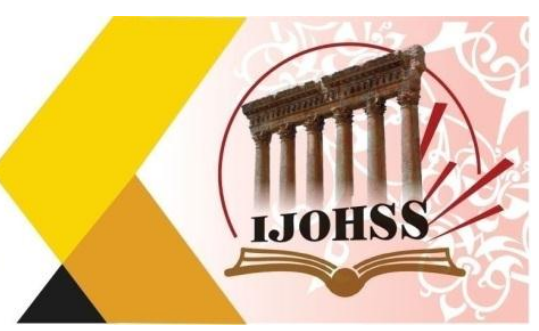

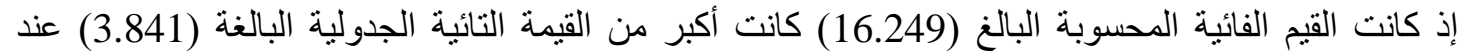

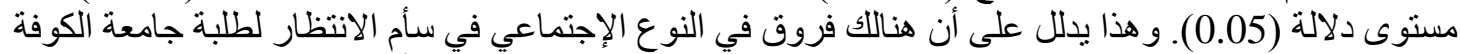

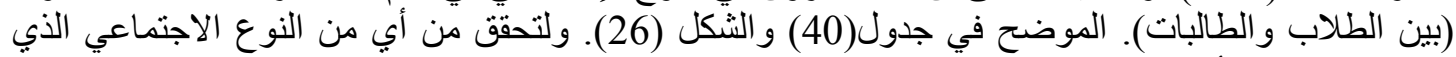

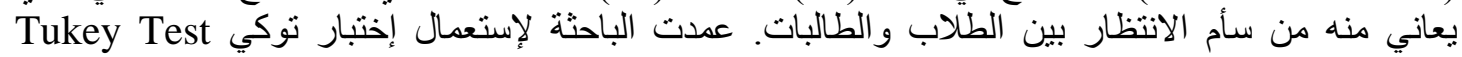

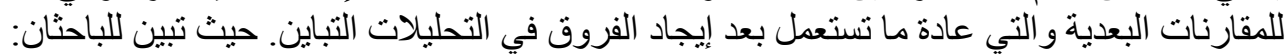

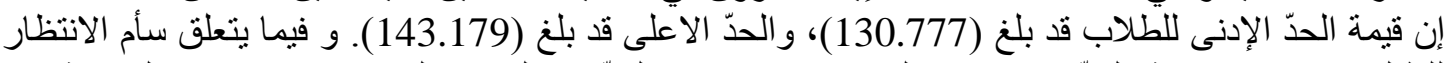

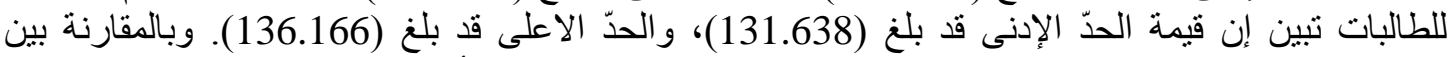

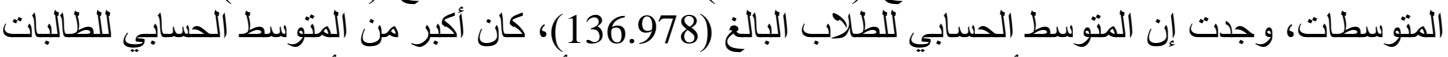
البالغ (133.902). و هذا يعني أن الطلاب في جامعة الكوفة هم أكثر معناة من سأم الانتظار من الطالبات،

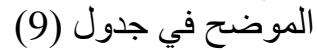

2-الفروف الدالة إحصائيا في متغير التخصص الاكاديمي

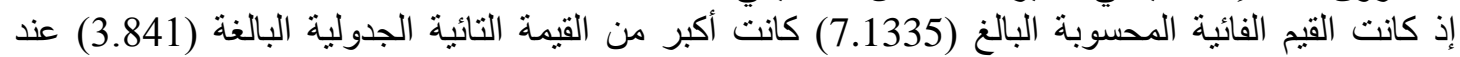

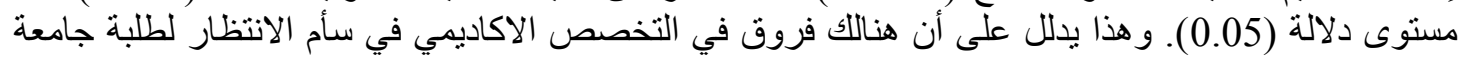

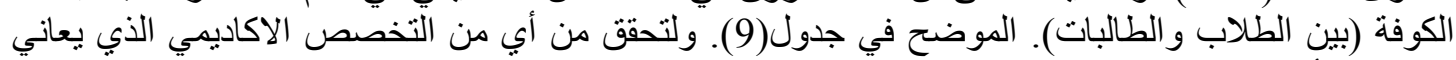

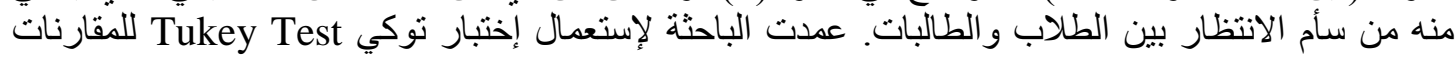

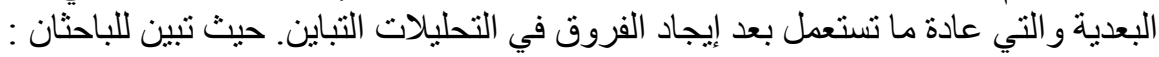

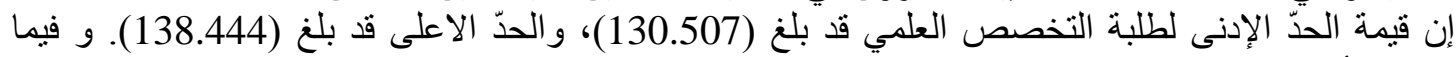

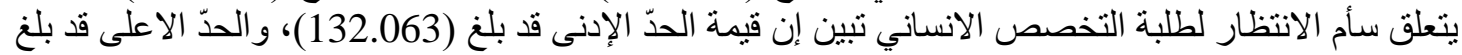

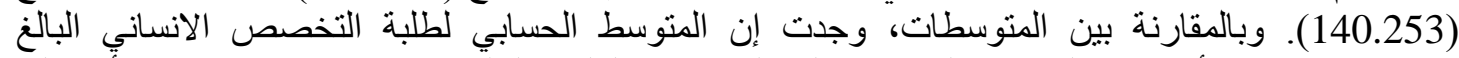

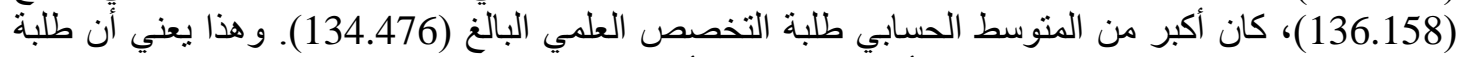
التخصص الانساني في جامعة الكوفة هم أكثر معناة من سأم الانتظار من طلبة التخصص التص العلمي، الموضح في

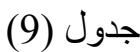

3-الفروق الدالة إحصائيا في متغير الصف الدار اسي (4) كالئ

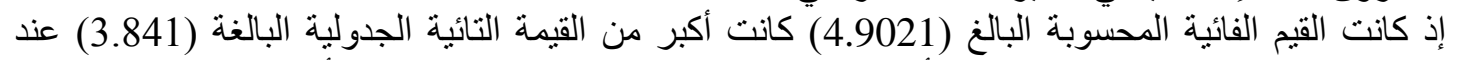

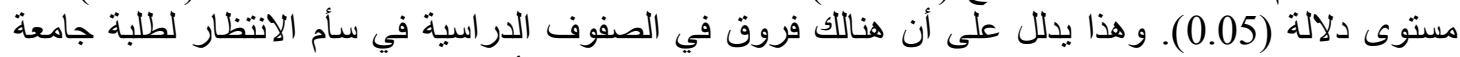

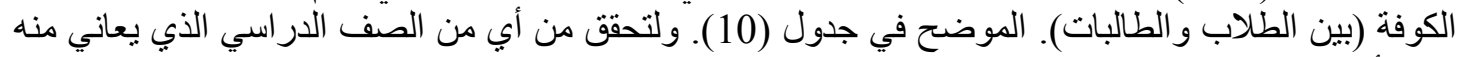

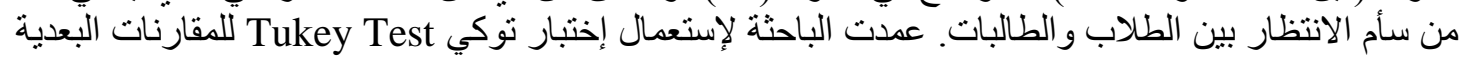

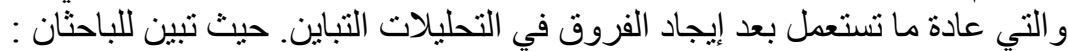

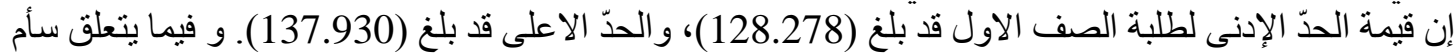

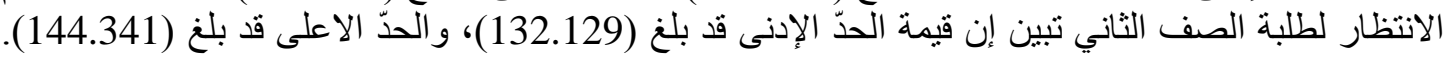

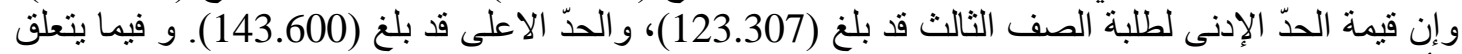

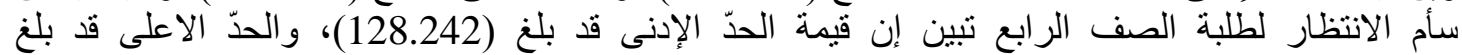

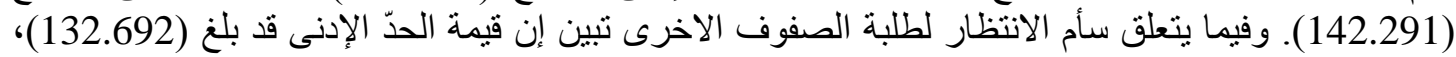

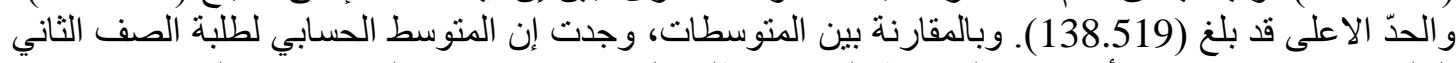

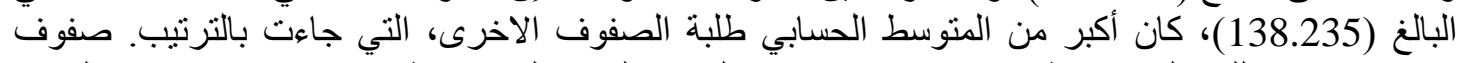

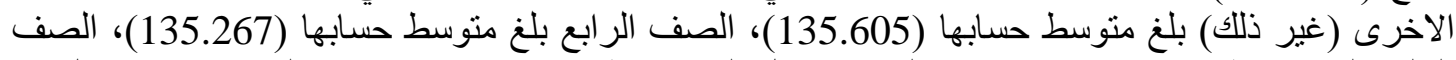

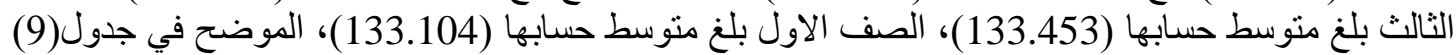

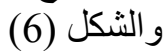

ثالثا: القيم غير دالة على الفروق في سأم الانتظار :

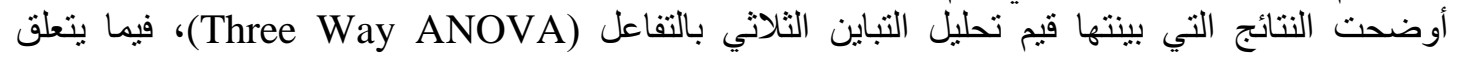

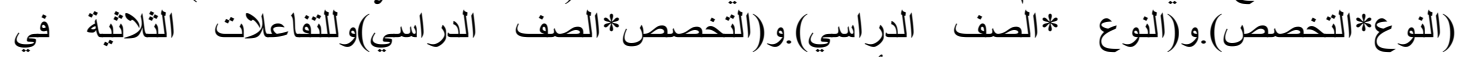

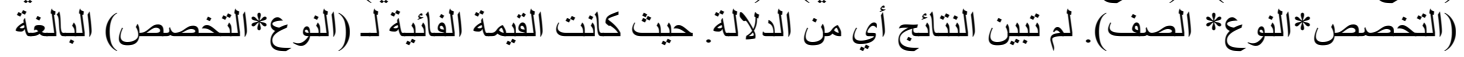




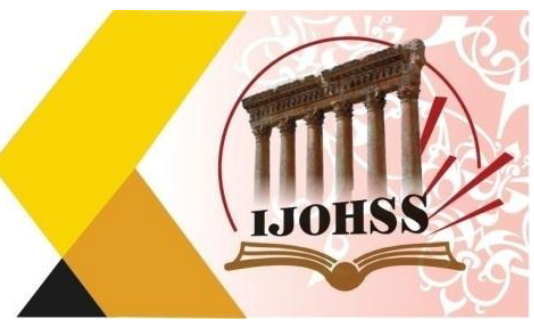

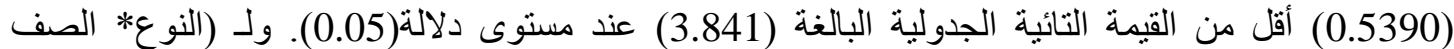

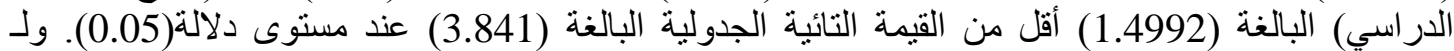
(التخصص* (الصف الدار اسي) البالغة (1.5864) أقل من القيمة التائية الجدولية البالغة (2.841) (3.841) عند مستوى

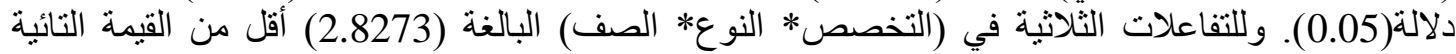

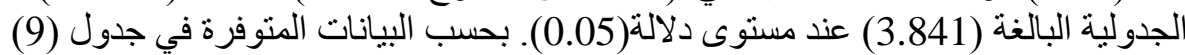

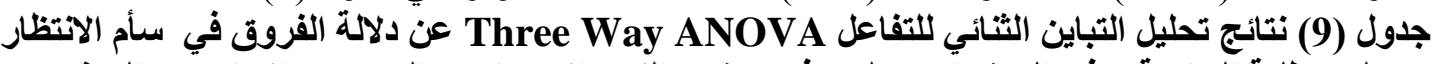

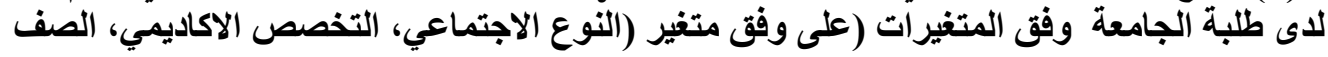
الار (اسي) (الني)

\begin{tabular}{|c|c|c|c|c|c|}
\hline $\begin{array}{r}\text { الدلالة } 0.05 \\
\text { p }\end{array}$ & 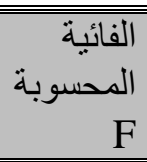 & متوسط & الحرجة & المربعات & مصادر التباين \\
\hline دال & 45.776 & 11641.3 & 1 & 11641.3 & سأم الانتظار \\
\hline دال & 16.249 & "4132.281 & 1 & "4132.281 & النوع الاجتماعي \\
\hline دال & 7.1335 & 14.09318 & 1 & 14.09318 & التخصص الاكاديمي \\
\hline دال & 4.9021 & 1246.644 & 4 & 4986.576 & الصف الدر اسي \\
\hline غير دال & 0.5390 & 137.079 & 1 & 137.079 & النوع * التخصص \\
\hline غير دال & 1.4992 & 381.267 & 1 & 381.267 & الدر اسىى $\quad$ * \\
\hline غير دال & 1.5864 & 403.433 & 1 & 403.433 & الدر اسصي * \\
\hline \multirow[t]{3}{*}{ غير دال } & 2.8273 & 719.012 & 2 & 1438.024 & التخفص * النوع * \\
\hline & & 254.3078 & 599 & 152330.360 & الخطاً \\
\hline & & & 611 & 177264.4 & الكلي \\
\hline
\end{tabular}

القيمة الفائية الجدولية تساوي (3.841) عند مستوى دلالة (0.05)

جدول (10) إختبار توكي Tukey Test للمقارنات البعدية في المتغيرات الدالة على مقياس سأم الانتظار

\begin{tabular}{|c|c|c|c|c|c|c|}
\hline $\begin{array}{r}\text { الحد الاعلى } \\
\text { Upper } \\
\text { Bound } \\
\end{array}$ & $\begin{array}{c}\text { الحد الادنى } \\
\text { Lower } \\
\text { Bound } \\
\end{array}$ & $\begin{array}{r}\text { المعياري } \\
\text { Std. Error } \\
\text { Std } \\
\end{array}$ & $\begin{array}{l}\text { الحسابي } \\
\text { Mean } \\
\end{array}$ & $\begin{array}{r}\text { المقارنات الفرعية } \\
\text { subcomponent's }\end{array}$ & $\begin{array}{r}\text { المقارنات } \\
\text { Comparisons }\end{array}$ & $\begin{array}{r}\text { المتغير } \\
\text { variable }\end{array}$ \\
\hline 143.179 & 130.777 & 3.158 & 136.978 & طلاب & \multirow{2}{*}{ النوع الاجتماعي } & \multirow{9}{*}{ سأم الانظار } \\
\hline 136.166 & 131.638 & 1.153 & 133.902 & طالبات & & \\
\hline 138.444 & 130.507 & 2.021 & 134.476 & علمي & التخصص & \\
\hline 140.253 & 132.063 & 2.085 & 136.158 & إنساني & الاكاديمي & \\
\hline 137.930 & 128.278 & 2.457 & 133.104 & الاول & \multirow{5}{*}{ الصف الدر اسي } & \\
\hline 144.341 & 132.129 & 3.109 & 138.235 & الثاني & & \\
\hline 143.600 & 123.307 & 5.166 & 133.453 & الثالث & & \\
\hline 142.291 & 128.242 & 3.577 & 135.267 & الر ابع & & \\
\hline 138.519 & 132.692 & 1.484 & 135.605 & غير ذللك & & \\
\hline
\end{tabular}


أنّ طلبة جامعة الكوفة بعانون من سأم الانتظار المرتبط بمشكلات إجتماعية تتعلق بالقيم الاجتماعية. ومشكلات الالنز ام العقدي و القيم الاعتقادية. 2.وجدت إن سأم الانتظار كان على الترتيب لطلبة الصف الثاني ثم الصف الرابع ثم الصف الثالث ثم الصف

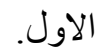

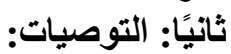
على وفق الإستنتاجات التي توصيات: توصل اليها الباحثان. لذا يوصيان بالآتي:

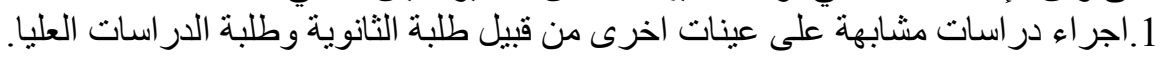

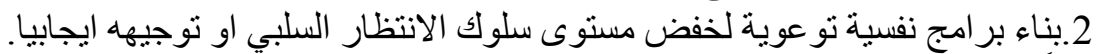

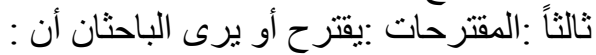

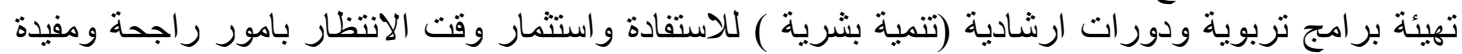

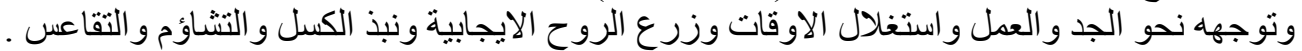

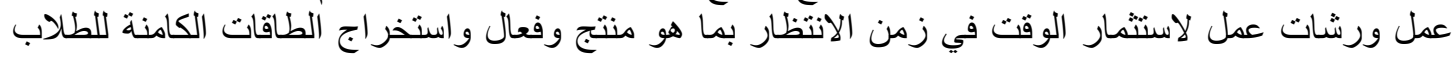

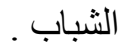
تعزيز وتطوير الطاقات و القابليات الموجودة نحو الاحسن و الافضل بشكل جاذب وتذكير هم بمبدأ الثواب و العقاب

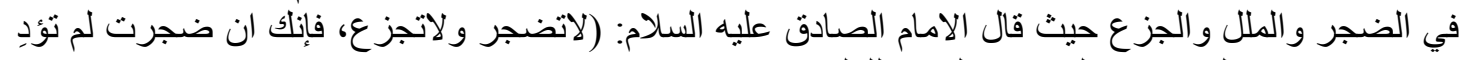
حقا، وان جز عت لم تصبر على حق).الكافي للكليني .

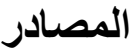
القرآن الكريم 1. كتب الحديث والسيرة : الكليني ، محمد بن يعقوب ،(الكافي )،ج 1 كتاب العقل والجهل ط طبعة بيروت

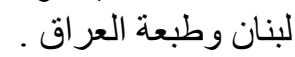
2. أبن منظور ،محمد مكرم بن منظور الافريقي(1405): معجم لسان العرب ،بيروت ـ لبنان ، الناثر مطبعة أدب الحوزة ومطبعة دار المعارف. 3. اثثانوس، زكريا و البياتي، عبد الجبار نوفيق (1977): المدخل في التحليل العاملي ، الجامعة المستنصرية ،

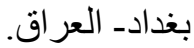

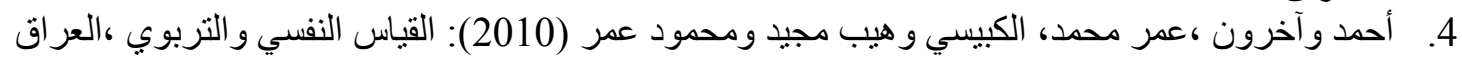

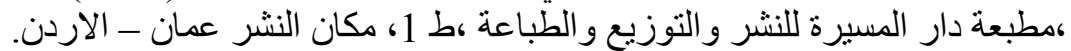

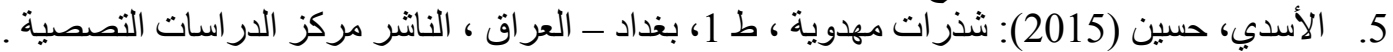

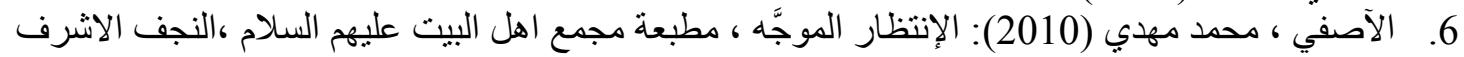

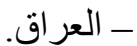

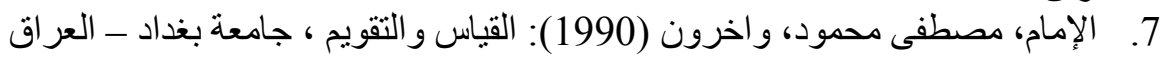

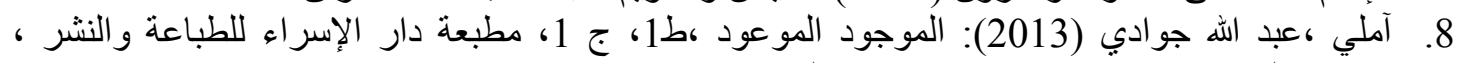

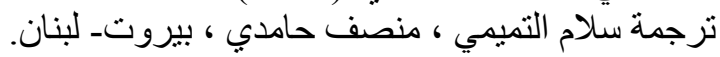

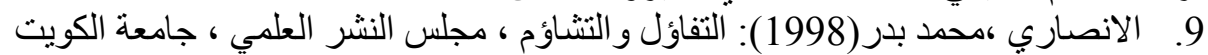

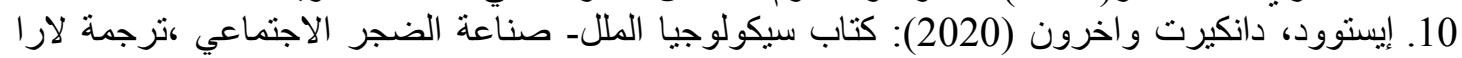

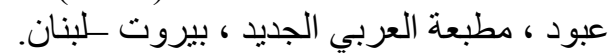

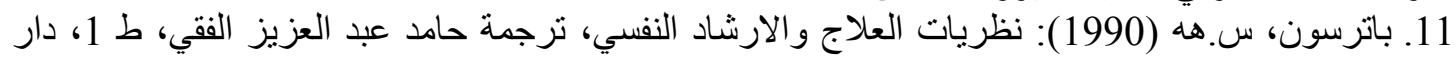
القلم للنشر و التوزيع ، الكويت.

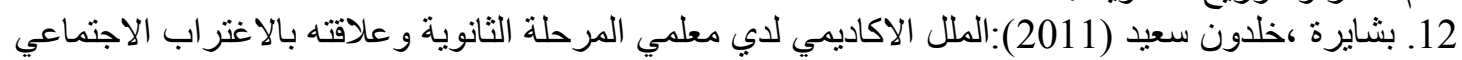

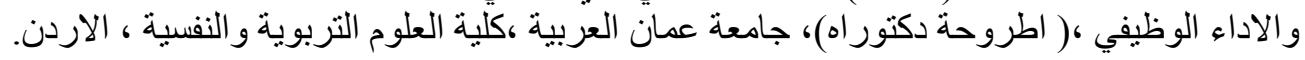




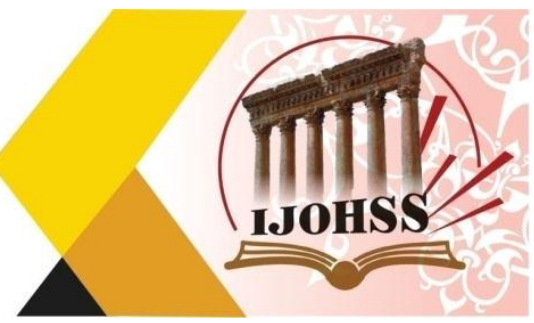

13. بو فارس ومداب ، عبد الرحمن (2018): الملل الاكاديمي لدى تلاميذ المرحلة الثانوية ،وهران ، مطبعة

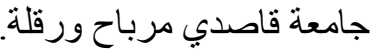

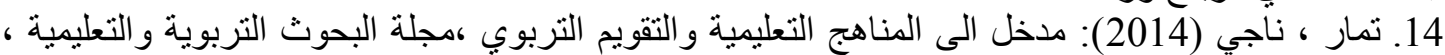

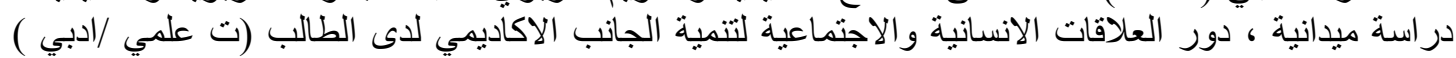

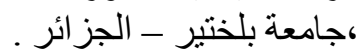
15. توكي ، بيتر (2008): المقارنات البعدية ، (Tukey Test)، الاردن ، الجامعة الاردنية ـ كلية التربية ، الاحصاء. 16. تيغزة، محمد بو زيان (2012): التحليل العاملي الاستكثافي و التوكيدي مفاهيمياً ومنهجيّاً بتوظيف حزمة

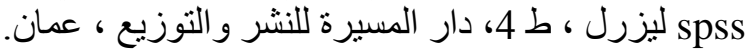
17. ثورندايك، روبرت طيرت وهيجن، اليزابيث (1980): القياس و التقويم في علم النفس التربوي، (ترجمة عبد الله

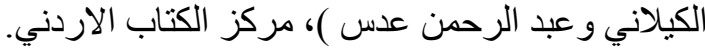

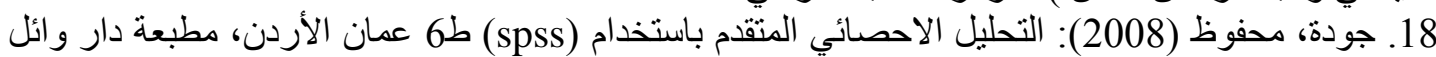

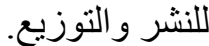
19. أبو حطب ، فؤ اد و عثمان ، سيد احمد وصادق ،آمال (2008):التقويم النفسي ، ط2 ،مكتبة الانجلو المصرية

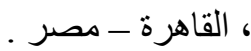

20. زروالي ، لطيفة (2016): معالجة التمثيلات الاجتماعية الخاصة بمشاعر اليأس في الاوساط التعليمية ، و هران ، مطبعة دار الكنوز للنشر . 21. زيعور ، علي ( 1984) : مذانب علم علم النفس المعاصرة ، لبنان ، دار الاندلس للطباعة والنشر.

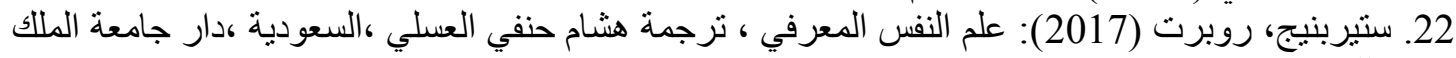
سعود للنشر. 23. سليمان ، كامل (2012): يوم الخلاص ،ط 1، ج 1، مطبعة دار الكتاب اللبناني و دار الكتاب العربي ،

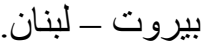
24. شوبنهاور، آرثر (2014): الحياة ار ادة وتمثل ـ هذا هو مصدر الالم و الملل، ط 1،الناشر منشورات ضفاف العبات

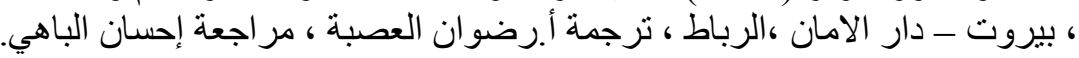

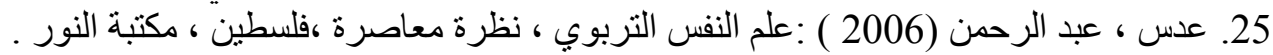

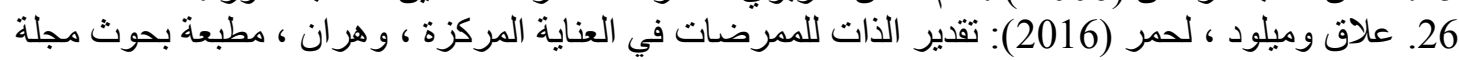

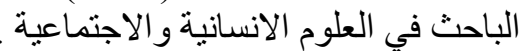
27. أبو علام ، رجاء محمود (2013): مناهج البحث في العلوم النفسية والتربوية ، مطبعة دار النشر للجامعات

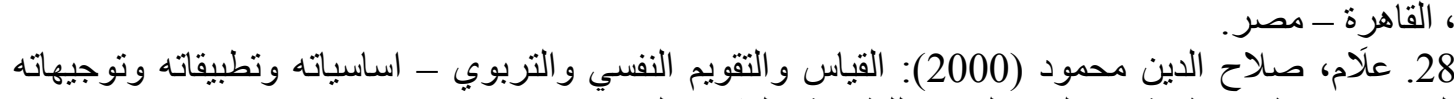
المعاصرة ، ط1، مطبعة دار الفكر العربي للطباعة و النشر ، القاهرة الفين - مصر. 29. عودة ،احمد سلمان وملكاوي ، فتحي داري حسن (1992): اساليب البحث العلمي في التربية و العلوم الانسانية ،

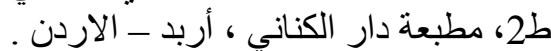

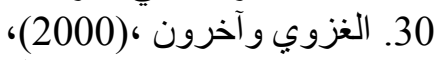

31. فرج ، صنفوت (1980) التحليل العاملي نظريا و عمليا في العلوم الانسانية ، ط1 ، مطبعة عالم الكتب ،

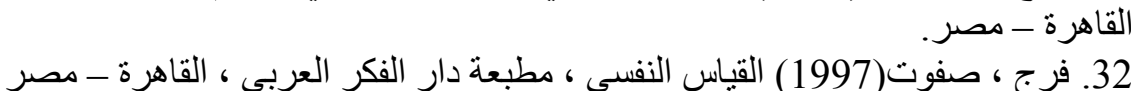

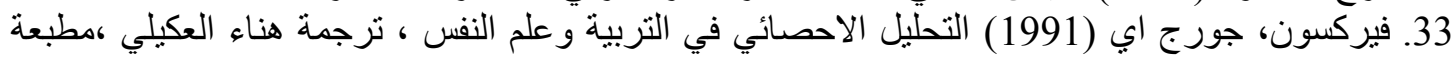

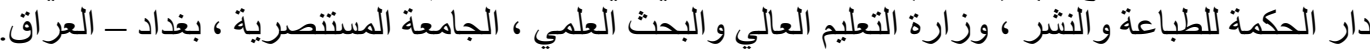

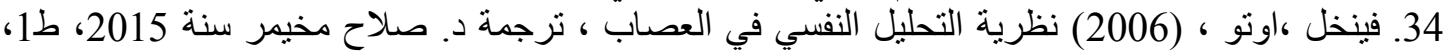

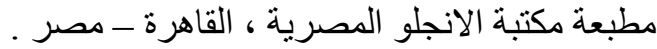




\section{المجلة اللحولية اللملوم الآنسانية والامتماعية}

International Journal on Humanities and Social Sciences websiteawww.ijohss.com Email:editor@ijohss.com ISSN: $2415-4822$

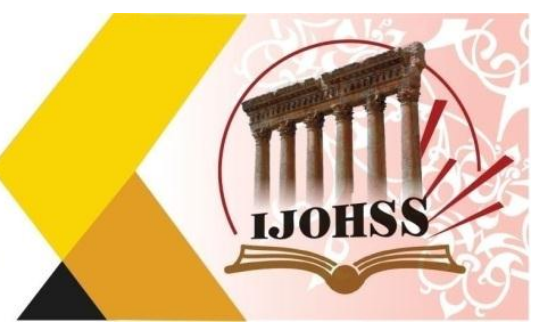

35. لييس ، ثيودور (2012)، Why we Get Bored، لماذا نشعر بالسأم ؟!،بحث مقدم في جامعة ميونخ المانيا ، ترجمة د. بـثار الجميلي . 36. اليعقوبي ، حيدر حسن (2012): القياس و التقويم في العلوم التربوية والنفسية ،مطبعة دار الكفيل للطباعة

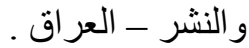

37. Alken,L.R.(1988), Physiological Utestinguandiassesen, Boston, Allyn \& Bascom 38. Allen, M. J., \& yen, W. M. (1979), Introduction toMeasurement Theory. Brook Cole, Publishing Company.

39. Allen, M. J., \& yen, W. M. (1979), Introduction toMeasurement Theory, Brook Cole, Publishing Company.

40. Allport, G . (1961), Pottern and Growth in personality ,London Holt Rinethart and Winston .

41. Anastasia \& Uibina, S (1997), Psychological Testing (7thed). NJ: Prentice Hall.

42. Anastasia, A. (1976), Psychological Testing, New York, 6th,Macmillan publishing Inc.

43. Anastasia. A. (1988), Psychology testing (6th ed). New York:

44. Andrew Solomon ;2020, ;30Macmillan.Bartlett, 2014; 117

45. Cronbach, L. J. (1964), Essential of Psychology testing. NewYork: Harper \& Brothers

46. Davidson (Eds.), The Nature of -Emotion: FundamentalQuestions (pp. 59-67). New York: Oxford University Press.

47. Dvid R. Hamiton (2012), Is your life mapped out?? Respress (C) S2021 .

48. Ekman P. (1994), Mood, emotions and traits. In P.Ekman \&R. J. Davidson (Eds.). The Nature of Emotion: FundamentalQuestions.

49. Forest, D., Clark, M., Mills, J., \& Isen, A. (1979). Helping as afunction of feeling state and nature of the helping behavior.Motivation and Emotion, 3(2), pp. 161-169.

50. Frijda. N.H. (1994), On Varieties of Affect: Emotion andepisodes, moods, and sentiments. In P.Ekman \& R. J.

51. Ghisell, E.E. et al. (1981), Measurement Theory for theBehavioral Sciences. San Francisco, Free man \& Company.

52. Gronlund, N. E. (1981), Measurement and Evaluation inTeaching.

53. Gronlund, N. E. (1981): Measurement and evaluation in Teaching.

54. Guilford, J. P. (1952) Cognitive styles: What are they?Educational and Psychological measurement 40, ;500 .

55. Guilford, J. P. (1954): General psychology (5th)، New York: D Van Nostrand Company.

56. Harrison, A. (1983): Language testing‘London: Macmillan Press

57. Lebon A. Migration et nationalite en France, 1998, ministere de I,Emploi et la Solidarite.

58. Linda B. Buck , 1980, University of Washington , Seattle,Howard Hughes Medical Institute, Columbia University Harvard University.

59. Mayer, j.D \& Stevenes, A.A.(1994), AN EmergingUnderstanding of Reflective (Meta) Experience of Mood.journal of research of personality, 28, 351-373. 


\section{المبلة اللحولية اللملوم الآنسانية والامتماعية}

International Journal on Humanities and Social Sciences websiteawww.ijohss.com Email:editor@ijohss.com العدد (28) ديسمبر 2021 Volume (28) December 2021

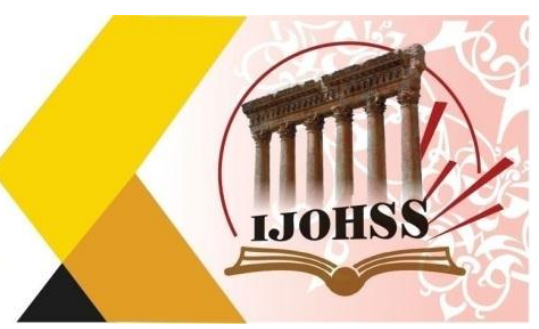

60. Myers , I ,B \& Briggers , P, (1995), Gift differing :understanding personality type . devise publishing ,Palo alto, California , 2nded.

61. New York, Brunner / Mazel.

62. Nunnally, J.C. (1976). Introduction To PsychologicalMeasurement. New York: McGraw-Hill, (1976); 262 .

63. Sullivan, D. (2009): Executive Functions, The Sage Glossary Of The Social andBehavioral Sciences, Thousand Oaks, CA: Sage Reference, (191).

64. Thomas, A. \&S. Chess (1977) Temperament \& Development. 